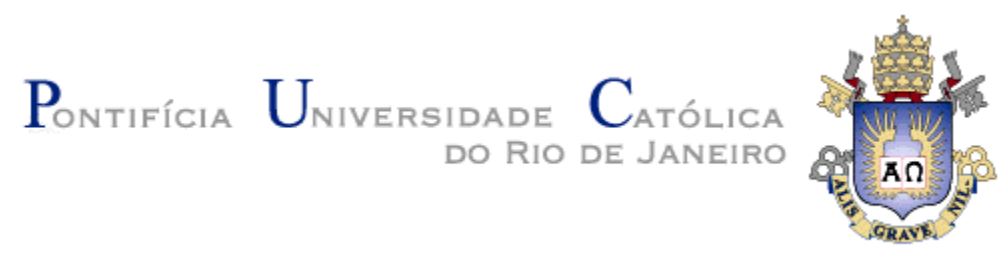

Leandro Magalhães de Oliveira

\title{
"And yet to times in hope my verse shall stand": uma breve história das traduções brasileiras dos sonetos shakespearianos
}

Dissertação de Mestrado

Dissertação apresentada como requisito parcial para obtenção do grau de Mestre em Estudos da Linguagem/Letras pelo Programa de Pós-graduação em Estudos da Linguagem, do Departamento de Letras da PUC-Rio.

Orientadora: Profa. Marcia do Amaral Peixoto Martins Coorientador: Prof. Leonardo Bérenger Alves Carneiro

Rio de Janeiro Abril de 2021 


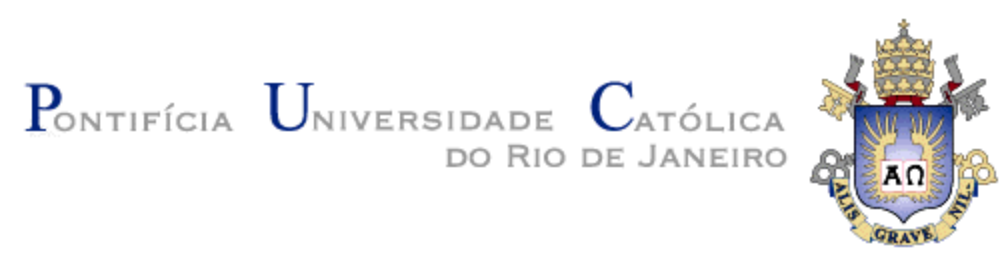

Leandro Magalhães de Oliveira

\section{"And yet to times in hope my verse shall stand": uma breve história das traduções brasileiras dos sonetos shakespearianos}

Dissertação apresentada como requisito parcial para obtenção do grau de Mestre pelo Programa de Pós-graduação em Estudos da Linguagem da PUC-Rio. Aprovada pela Comissão Examinadora abaixo assinada:

Profa. Marcia do Amaral Peixoto Martins Orientador Departamento de Letras da PUC-Rio

Prof. Leonardo Bérenger Alves Carneiro Coorientador Departamento de Letras da PUC-Rio Profa. Luci Maria Dias Collin UFPR

Profa. Marlene Soares dos Santos UFRJ

Rio de Janeiro, 15 de abril de 2021 
Todos os direitos reservados. A reprodução, total ou parcial, do trabalho é proibida sem autorização do autor, do orientador e da universidade.

\section{Leandro Magalhães de Oliveira}

Graduou-se em Letras (Português/Inglês) na Fundação Educacional Unificada Campograndense (FEUC) em 2014 e se especializou em tradução em língua inglesa pela Universidade Estácio de Sá em 2018. Tem interesse em pesquisas que dialogam sobre os estudos da tradução, bem como os estudos shakespearianos.

Ficha Catalográfica

Oliveira, Leandro Magalhães de

"And yet to times in hope my verse shall stand" : uma breve história das traduções brasileiras dos sonetos shakespearianos / Leandro Magalhães de Oliveira ; orientadora: Marcia do Amaral Peixoto Martins ; coorientador: Leonardo Bérenger Alves Carneiro. - 2021.

146 f. ; $30 \mathrm{~cm}$

1. Dissertação (mestrado)-Pontifícia Universidade Católica do Rio de Janeiro, Departamento de Letras, 2021.

Inclui bibliografia

1. Letras - Teses. 2. William Shakespeare. 3. Soneto. 4. Tradutores brasileiros. 5. Sonetos de Shakespeare em português do Brasil. 6. Historiografia da tradução no Brasil. I. Martins, Marcia do Amaral Peixoto. II. Carneiro, Leonardo Bérenger Alves. III. Pontifícia Universidade Católica do Rio de Janeiro. Departamento de Letras. IV. Título. 


\section{Agradecimentos}

Primeiramente a Deus, por tudo.

Aos meus pais, Ricardo Oliveira e Lucimar Oliveira, e a minha esposa Rhayany Magalhães, por todo o apoio e incentivo.

Também à Vice-Reitoria Acadêmica da PUC-Rio, pela bolsa concedida. À Secretaria de Letras, em especial a Chiquinha, incansável na sua dedicação e preocupação com os alunos.

Aos professores do PPGEL, sobretudo aos que me orientaram neste trabalho, Profa. Marcia do Amaral Peixoto Martins e Prof. Leonardo Bérenger Alves Carneiro.

De modo especial, agradeço àqueles que compõem a banca da minha defesa, Profas. Marlene Soares dos Santos; Luci Collin, e Prof. Paulo Henriques Britto.

O presente trabalho foi realizado com apoio da Coordenação de Aperfeiçoamento de Pessoal de Nível Superior - Brasil (CAPES) - Código de Financiamento 001.

A todos minha gratidão. 


\section{Resumo}

Oliveira, Leandro Magalhães de.; Martins, Marcia do Amaral Peixoto (Orientadora); Carneiro, Leonardo Bérenger Alves (Coorientador). "And yet to times in hope my verse shall stand": uma breve história das traduções brasileiras dos sonetos shakespearianos. Rio de Janeiro, 2021. 146p. Dissertação de Mestrado - Departamento de Letras, Pontifícia Universidade Católica do Rio de Janeiro.

Objetiva-se nesta dissertação desenvolver um estudo historiográfico das traduções brasileiras dos sonetos shakespearianos, que começaram a ser publicadas no final do século XIX, enfocando traduções e tradutores. Levando em consideração algumas das indagações de Lieven D'hulst (2010) que interessam à historiografia da tradução, buscam-se respostas para as questões “'Quis?', '“Quomodo?’ e “Quando?”, que visam, respectivamente, caracterizar a figura do tradutor e a sua inserção no sistema literário brasileiro; analisar estratégias tradutórias globais empregadas por cada profissional e depreender as noções de tradução que norteiam o seu trabalho; e identificar o contexto em que tais traduções passam a integrar o sistema literário brasileiro. Esta dissertação se ancora em abordagens e conceitos dos Estudos da Tradução e Estudos Shakespearianos; no primeiro caso, em teóricos como D’hulst (2010), Pym (2014) e Pinilla (2020), e no segundo, em Spiller (1992) e Hyland (2002). Destacam-se, na bibliografia sobre os sonetos produzidos por Shakespeare, Collin (2008), Edmondson \& Wells (2004) e Duncan-Jones (1997); e sobre as traduções da poesia lírica desse poeta para o português do Brasil, os estudos de Wanderley (1991), Silva Ramos (2008) e Walker (2018). No período de quase 12 décadas, 18 tradutores publicaram traduções brasileiras integrais ou parciais da série de 154 sonetos, recorrendo a diferentes esquemas formais, constituindo um repertório rico e diversificado à disposição dos leitores falantes do português. Ao analisar essas traduções e tradutores, espera-se contribuir para a historiografia da tradução no Brasil em geral e a dos sonetos de Shakespeare em particular.

\section{Palavras-chave:}

William Shakespeare; Soneto; Tradutores brasileiros; Sonetos de Shakespeare em português do Brasil; Historiografia da tradução no Brasil. 


\section{Abstract}

Oliveira, Leandro Magalhães de. Martins, Marcia do Amaral Peixoto (Advisor); Carneiro, Leonardo Bérenger Alves (Co-Advisor). "And yet to times in hope my verse shall stand": a brief history of Brazilian translations of the Shakespearian Sonnets. Rio de Janeiro, 2021. 146p. Dissertação de Mestrado - Departamento de Letras, Pontifícia Universidade Católica do Rio de Janeiro.

This thesis aims to conduct a historiographical study on Brazilian translations of Shakespeare's sonnets, which began to be published in the late 19th century, focusing on translations and translators. Considering a number of questions posed by Lieven D'hulst (2010) that interest the historiography of translation, we seek answers for "Quis?", "Quomodo?", and "Quando?" that aim, respectively, to characterize the figure of the translator and his/her insertion into the Brazilian literary system; to analyze the global strategies of translation applied by each professional as well as to apprehend the notions of translation which guided his/her work; and to identify the context in which these translations become part of the Brazilian literary system. This research is informed by approaches and concepts of Translation Studies and Shakespearean Studies; in the first case, by theorists such as D'hulst (2010), Pym (2014) and Pinilla (2020); in the second, by Spiller (1992) and Hyland (2002). Regarding Shakespeare's sonnets, Collin (2008), Edmondson \& Wells (2004) and Duncan-Jones (1997) stand out; and as to Shakespeare's lyric poetry in Brazilian Portuguese translations, the critical works of Wanderley (1991), Silva Ramos (2008) and Walker (2018) were fundamental. In the period of nearly 12 decades, 18 translators published full or partial Brazilian translations of the 154-sonnet series, using different formal schemes, thus constituting a rich and diversified repertoire available to Portuguese-speaking readers. By analyzing these translations and translators, we expect to contribute to the historiography of translation in Brazil in general and that of Shakespeare's sonnets in particular.

\section{Keywords:}

William Shakespeare; Sonnet; Brazilian translators; Shakespeare's sonnets in Brazilian Portuguese; Historiography of translation in Brazil. 


\section{Sumário}

1. Introdução 8

2. Fundamentação teórica 14

3. O trajeto do soneto: de Francisco Petrarca a William Shakespeare 30

4. Os sonetos de Shakespeare $\quad 57$

5. Shakespeare em tradução no brasil: brevíssimo relato 69

5.1 A tradução dos sonetos para o português do Brasil 71

6. A difusão de The Sonnets no Brasil: tradutores e traduções 77

7. Considerações finais

8. Referências bibliográficas

APÊNDICE A - Quadro panorâmico dos tradutores e de suas respectivas traduções dos sonetos shakespearianos publicadas no Brasil

APÊNDICE B - Breve troca de mensagens com Oscar Dourado 146 


\section{1 \\ INTRODUÇÃO}

These offices, so oft as thou wilt look,

Shall profit thee, and much enrich thy book. WILLIAM SHAKESPEARE (sonnet 77)

O Shakespeare encontrado em The Sonnets é dono de uma eloquência que, segundo tradutores ${ }^{1}$ de seus sonetos, é a característica de maior destaque em seu trabalho lírico, pois, ao transcender o contexto e "luzir num céu exclusivo" (WANDERLEY, 1991, p. 10), amplia a dinâmica entre pensamento e linguagem, lançando mão de artifícios retóricos complexos dentro de uma forma poética fixa. Além disso, a dimensão mundial que o poeta inglês e suas obras alcançaram já faz com que alguns de seus tradutores afirmem que Shakespeare "venceu o espaço, pois hoje não é visto como inglês, mas como universal" (FUNCK, 2019, p.14). Diante dessa universalidade, interessei-me por investigar a inserção do Bardo no Brasil, enfocando as diferentes traduções publicadas de seus sonetos, bem como seus respectivos tradutores, considerando o contexto histórico e estético em que se deram tais publicações.

Em determinado momento, questionei-me acerca da relevância de se estudar a temática shakespeariana, diante dos vastos estudos já realizados e disponíveis ao público, e pude constatar que a vida e obra de Shakespeare têm, de fato, produzido uma multiplicidade de estudos, como, por exemplo, trabalhos publicados em revistas acadêmicas, livros autorais, coletâneas e ensaios variados, que abordam o poeta inglês e sua obra à luz de novas e diversas teorias. Sua produção lírica e dramatúrgica tem sido constantemente (re)lida e (re)interpretada sob a ótica de teorias tanto mais recentes quanto consagradas há mais tempo, como a psicanálise, o marxismo, os estudos de viés feminista e de gênero, os queer studies, o multiculturalismo, a desconstrução de Jacques Derrida e a Nova História, entre outras, tal como salientado por Martins (1999) em sua tese que trata das traduções brasileiras

\footnotetext{
1 Shakespeare tem tido, no Brasil, tradutores e tradutoras, as quais merecem igualmente destaque nas formas da língua portuguesa. Entretanto, visando não sobrecarregar o texto com a forma "tradutor/a" ou "tradutores/as" e com a necessidade de prever dupla concordância para todos os adjetivos que poderão acompanhar tais vocábulos, optei por usar o genérico masculino, tanto no singular como no plural.
} 
de Hamlet. Entretanto, pude atestar que a pesquisa acerca de Shakespeare não se esgota de forma alguma, pois sempre há espaço para investigações inovadoras e fundamentadas em novas teorias.

De maneira mais específica, no Brasil, tanto a obra lírica do poeta inglês como a dramática despertam muito interesse e ainda hoje são traduzidas e analisadas, o que fomenta novas interpretações, como já foi dito. Escrita predominantemente em pentâmetros iâmbicos, combinando verso livre, verso rimado e prosa, o drama shakespeariano tem sido traduzido das mais diversas formas: em prosa e versos decassílabos, em prosa e versos dodecassílabos ou integralmente em prosa; e quanto à linguagem, pode tender mais para a erudição, arcaização e formalidade, ou para um vocabulário mais contemporâneo e estilo mais informal. Os sonetos, por sua vez, produzidos em pentâmetros iâmbicos rimados, também vêm sendo traduzidos de formas diversas, o que oferece aos leitores e estudiosos brasileiros uma amplitude de escolhas. Isso me faz recordar das palavras do estudioso e tradutor dos sonetos de Shakespeare, Péricles Eugênio da Silva Ramos (2008 p. 9): "não há traduções exatas, há, isto sim, reexpressões algumas vezes felizes de textos estrangeiros". Portanto, o ato tradutório não está em uma posição secundária e de passividade, mas sim, como esse mesmo tradutor afirma, “Traduzir é assim recriar" (p. 9). Isso significa dizer que, dada a variedade das traduções das obras do Bardo que foram publicadas em português do Brasil, é de fundamental importância mapeá-las e analisá-las, a fim de fornecer dados pertinentes para uma historiografia das traduções shakespearianas para 0 português brasileiro. Todavia, vale salientar que, no que tange às obras dramáticas, a base de dados disponível no portal "Escolha seu Shakespeare"2 tem sido responsável por promover um amplo levantamento, constantemente atualizado, das traduções brasileiras das peças. Sendo assim, este trabalho visa o caminho das obras líricas, especificamente as traduções de The Sonnets para o português do Brasil, enfocando seus tradutores e respectivos

2 MARTINS, Marcia A. P. Escolha seu Shakespeare. Disponível em: http://www.dbd.pucrio.br/shakespeare/index.htm. Acesso em: 31 mar. 2020. 
trabalhos, inserindo-os dentro dos seus contextos. A proposta da minha pesquisa é, portanto, buscar determinar quem são esses tradutores, quantos são, quantas traduções cada um realizou e publicou, como são suas traduções em termos formais e semânticos e em que momento da cena literária e cultural estavam ou estão inseridos. Tais indagações serão fundamentadas e discutidas posteriormente.

Outro fator que merece atenção é que, ao se fazer um levantamento junto a bases de dados como teses, dissertações, catálogos de bibliotecas, anais e artigos, por exemplo, as peças shakespearianas recebem maior foco nas pesquisas desenvolvidas no Brasil, em comparação com os sonetos. No que concerne aos tradutores dessa obra lírica, o problema se acentua ainda mais, colaborando assim para a invisibilidade do tradutor, tão combatida por Lawrence Venuti em suas teorizações (2008), e gerando até mesmo trabalhos com pouca abrangência investigativa nesse aspecto. Um exemplo bem breve dessa afirmação é que comumente, ao se folhear livros dedicados às obras de Shakespeare traduzidas para o português do Brasil, seja em projetos de tradução ou em obras publicadas para esse fim, percebe-se a carência de conteúdo referente à história das traduções ou dos tradutores dos sonetos no Brasil. Em muitos estudos mais abrangentes sobre as traduções, são as peças que merecem maior atenção, como já foi dito, enquanto os sonetos são abordados mais superficialmente e de modo generalizante. Ocorre, por exemplo, que uma obra consagrada que enfoca a influência do poeta inglês no Brasil, Shakespeare no Brasil de Eugênio Gomes (1961), referência para os estudos shakespearianos, dedica ao tema apenas um capítulo curto, de cinco páginas, onde tece algumas considerações sobre os desafios que a tradução dos sonetos apresenta. Ao ler a seção, as seguintes indagações são possíveis: Quem foi o primeiro tradutor dos sonetos no Brasil? Traduziu toda a coleção de sonetos? Buscou se aproximar dos aspectos formais e semânticos da obra na língua de partida ou foi subversivo? Qual era o contexto literário da época em que publicou sua tradução? É possível identificar a influência das poéticas predominantes? Gomes (1961) apenas faz referência 
a Silva Ramos, que no ano de 1953 havia publicado 33 sonetos, só que dois outros tradutores já haviam feito o mesmo antes dele no Brasil, como se apontará posteriormente nesta dissertação.

Similarmente, pode-se verificar, nas introduções das obras dos sonetos traduzidos, que geralmente os tradutores apresentam o contexto sóciohistórico no qual a obra originalmente se inseriu, isto é, o período elisabetanojaimesco, mas não elaboram ao menos um breve levantamento dos tradutores brasileiros que os precederam nessa complexa tarefa. Os que o fazem, somente apontam aqueles os quais foram objetos de suas consultas, como é o caso de Jorge Wanderley, que elenca quatro tradutores brasileiros, um português, dois italianos e um espanhol.

Em vista da carência acima problematizada, este trabalho de orientação historiográfica tem como objetivo contribuir com o levantamento e investigação do percurso das traduções dos sonetos de Shakespeare publicadas em português do Brasil, pretendendo sistematizar uma história de tais traduções, destacando os principais ${ }^{3}$ nomes que atuaram nessa empreitada. Para tanto, busco como metodologia responder às perguntas elaboradas por Lieven D'hulst (2010) que interessam à historiografia da tradução: Quem? Como? Quando? O quê?, enfocando respectivamente: na análise da figura do tradutor dos sonetos de Shakespeare; sua visão de tradução, normalmente encontrada em paratextos, isto é, reflexões acerca dos sonetos que acompanham a própria obra traduzida, que visa explanar o projeto tradutório e as definições que esse profissional atribui ao ato de traduzir, também entendidas como suas concepções/noções ${ }^{4}$ de tradução; e em metatextos - comentários críticos realizados sobre uma obra produzida e que são apresentados fora de tal edição, como por exemplo, entrevistas, artigos acadêmicos entre outros; o contexto literário da publicação dessas traduções e, evidentemente, as traduções propriamente ditas, observando as estratégias tradutórias globais

\footnotetext{
${ }^{3}$ A utilização de "principais" ocorre porque eu compreendo que haja tradutores informais que por algum motivo ou despretensão não publicaram suas traduções dos sonetos do Bardo.

4 Os termos "noção" e "conceito" neste trabalho serão utilizados de maneira intercambiável. Não distinguindo-se, portanto, "noção" de "concepção" tradutória, como faz Gambier (2019).
} 
empreendidas. Tais estratégias são compreendidas como as escolhas adotadas pelo tradutor que geralmente correspondem às suas concepções de tradução, podendo ser efetuadas tanto no âmbito formal quanto no semântico dos sonetos.

O corpus deste trabalho compreenderá a série de sonetos traduzidos e publicados em português brasileiro, por meio de um levantamento quantitativo, visando delinear um panorama das traduções e dos tradutores dos sonetos, descrever as óticas e estratégias tradutórias e apontar pontos de vista em comum ou díspares entre esses profissionais. Pretende-se também situar esta dissertação dentro das orientações de pesquisa no campo da historiografia das traduções no Brasil salientadas por José Antonio Sabio Pinilla (2020). Com os dados aqui obtidos, se tornará possível fornecer informações biográficas dos profissionais que traduziram os sonetos shakespearianos, quer a sequência na íntegra, quer sonetos escolhidos. Assim, para fins de análise, tais informações foram consolidadas sob forma de tabela (Apêndice 1 desta dissertação) para consulta rápida, composta dos seguintes campos: nome do tradutor, identificação dos sonetos traduzidos, editora e ano de publicação, concepções de tradução e estratégias tradutórias.

A fundamentação teórica da pesquisa conta com autores dos Estudos da Tradução e dos Estudos Shakespearianos. No primeiro campo, predominam teorizações de autores como Lieven D'hulst (2010), Sabio Pinilla (2020) e Anthony Pym (2014) voltadas para a historiografia da tradução, bem como estudiosos e tradutores, como Jorge Wanderley (1991), Silva Ramos (2008) e Shanta Walker (2018), que enfocaram a tradução da poesia lírica de Shakespeare. No campo dos estudos shakespearianos, destacam-se os trabalhos de Luci Collin (2008), Edmonson \& Wells (2004) e Katherine Duncan Jones (1997), que se debruçaram sobre os aspectos formais e semânticos dos sonetos.

No primeiro capítulo, abordo a difusão do soneto, lançando luz sobre os personagens de maior participação para o desenvolvimento e propagação na 
Europa da forma poética ${ }^{5}$ que se entende atualmente como soneto shakespeariano, buscando assinalar como Shakespeare se tornou uma figura que assume uma postura dual, ou seja, em seus poemas há traços que se aproximam do soneto inglês desenvolvido por seus predecessores Sir Thomas Wyatt (1503-1542), Henry Howard (1517-1547), o conde de Surrey e Sir Philip Sidney (1554-1586) e, às vezes, até de Francisco Petrarca (1304-1374); mas, por outro lado, subverte o modelo poético em certas circunstâncias. No segundo capítulo, volto-me especificamente para o Brasil e para a chegada dos sonetos às terras brasileiras, apresentando brevíssimos relatos, diante dos poucos registros encontrados. No terceiro capítulo, apresento os tradutores brasileiros dos sonetos de Shakespeare fornecendo dados biográficos e discutindo a respeito de suas traduções dos sonetos, bem como de suas noções e estratégias tradutórias conforme salientadas em seus paratextos e/ou metatextos e adotadas ao longo de suas obras. E, por fim, o quarto capítulo conta com as considerações finais e com os resultados obtidos a partir dos dados analisados. No apêndice, estará disposto um quadro panorâmico com os devidos dados levantados.

${ }^{5}$ Jacob Burckhardt ([1878] 1911) também atribui ao soneto o nome de "forma métrica". Portanto, utilizarei essa ocorrência como sinônimo de "forma poética" para dar fluidez ao texto. 


\section{2 \\ FUNDAMENTAÇÃO TEÓRICA}

The remarkable thing about Shakespeare is that he is really very good

- in spite of all the people who say he is very good. ROBERT GRAVES

Dentro dos pressupostos teóricos adotados para informar esta pesquisa, vale primeiramente ressaltar dois pilares: os Estudos Shakespearianos, com uma maior ênfase na obra lírica de Shakespeare, especificamente Os Sonetos, lançando luz acerca do que veio a ser conhecido como "soneto inglês", além de destacar os aspectos formais e semânticos trabalhado por Shakespeare; e os Estudos da Tradução, enfocando os estudos historiográficos alinhados a uma perspectiva não normativa, a fim de situar o trabalho no tempo e no espaço e seguir por uma ótica não essencialista do conceito de tradução. Além disso, questões que envolvem retraduções também serão abordadas.

No que concerne aos estudos sobre Shakespeare, o recorte que se faz é a análise de seus sonetos e do seu estilo poético nessa forma fixa. Abordase também o desenvolvimento do soneto ao longo do tempo na Inglaterra e o percurso das traduções de seus sonetos no Brasil.

Para a análise do uso que Shakespeare faz dessa forma métrica, utilizase como referencial teórico Peter Hyland (2002), Paul Edmondson e Stanley Wells (2004), Stephen Orgel e Blackmore Evans (2006) e Harold Bloom (2008), bem como o trabalho da pesquisadora da Universidade Federal do Paraná, Luci Collin, que estuda o soneto shakespeariano sob um enfoque histórico na Inglaterra; a dissertação de mestrado de Shanta Navvab Walker (2018), intitulada Para uma tradução comentada dos sonetos de Shakespeare; e reflexões de poetas que traduziram os sonetos de Shakespeare: Jorge Wanderley (1991), Péricles Eugênio da Silva Ramos (2008) e Elvio Funck (2019), que em seus prefácios discorrem sobre o soneto dentro do contexto elisabetano e da publicação da sequência em 1609.

Já no que tange às investigações historiográficas que visam contribuir para os Estudos da Tradução, Lieven D'hulst (2010), em seu artigo 
"Translation History", explicita duas indagações que orientam tal abordagem: de que maneira a tradução pode servir para a compreensão histórica de uma dada cultura, bem como para suas práticas socioculturais, religiosas e políticas? Ou o inverso: como a história pode colaborar para o entendimento dos diversos pensamentos sobre a tarefa tradutória, isto é, a tradução como um produto, um processo, uma alegoria, uma teoria entre outras possibilidades? Tais perguntas ratificam a importância de estudos historiográficos para o campo disciplinar da tradução. $O$ autor ainda vai além, ao apontar que, embora haja essas duas orientações que "calibrariam" o modo como a abordagem historiográfica deveria ser realizada, somente a segunda indagação embasa um número maior de pesquisas, sendo a primeira mais negligenciada pelos estudiosos. Contudo, o autor frisa de maneira otimista que, por causa da expansão e da evolução da tradução como campo disciplinar, a tendência é que as pesquisas historiográficas se intensifiquem e, consequentemente, as duas orientações poderão ser suficientemente contempladas como objeto investigativo.

D'hulst (2010) também elenca perguntas que podem direcionar as pesquisas sobre a tradução. São elas: Quis?, Quid?, Ubi?, Quibus auxiliis?, Cur?, Quomodo?, Quando? e Cui bono?, explicadas a seguir:

- “Quis?" é a pergunta correspondente a "quem?", ou seja, o enfoque é dado à pessoa do tradutor por um viés histórico, investigando seu contexto social, econômico, cultural, religioso, a nomear alguns; capacidade intelectual; relação profissional e formação, bem como outros aspectos inerentes à figura do tradutor. D'hulst (2010) chama atenção para o número reduzido de estudos desenvolvidos tendo o tradutor como foco, mas hoje, em 2021, observa-se que esse quadro vem aos poucos se revertendo.

- "Quid?" ou "o quê?" remete à seleção do que foi e o que não foi traduzido, levando em conta a investigação dos critérios e dos procedimentos de escolha do conteúdo traduzível. O autor frisa que 
analisar seguindo essa ótica pode oferecer subsídios para compreender o impacto que uma cultura exerce sobre a outra, visto que traduzir um determinado conteúdo pode afetar diretamente a realidade sociocultural de um povo. Isso pode ser observado nos inúmeros efeitos que as traduções francesas operaram durante o período do Brasil colonial, difundindo ideais iluministas que viriam a instigar posteriormente o espírito de liberdade e independência nacional frente ao poderio da monarquia de Portugal (WYLER, 2003).

- "Ubi?" é a investigação que visa determinar onde as traduções foram feitas, publicadas e vendidas, e por quem, ou seja, por quais editoras, no âmbito de quais séries ou coleções. Também é importante verificar se tal produção emana dos mesmos centros que publicam criações literárias originais (por exemplo, editoras estabelecidas nas capitais de países culturalmente hegemônicos) ou se é feita em locais periféricos, como cidades menores ou em países intermediários (D'HULST, 2001, p. 26). Tais fatores externos podem influenciar diretamente na recepção de uma tradução e ajudar a compreender o papel que uma dada tradução exerceu em um determinado país.

- "Quibus auxiliis?" é uma indagação que está ligada diretamente a questões de patronagem e outros mecanismos de controle que afetam o trabalho de tradução. Isso significa dizer que a investigação orientada sob essa ótica analisa, de maneira diacrônica, quais são as relações de poder estabelecidas na produção de uma tradução, bem como outros mecanismos secundários que possam ter exercido algum tipo de influência direta ou indireta na tradução e no tradutor.

- "Cur?" ou "por quê?" é a análise do motivo que leva uma tradução a ser produzida e a apresentar determinadas características: sua forma, sua função e seu efeito sociocultural. D'hulst (2010) aponta que a relação de causa e efeito na tradução é um dos principais objetos de análise desse campo disciplinar. No entanto, sob um viés histórico é necessário reformular as explicações de modo a levar em conta, entre 
outros fatores, procedimento tradutórios, coerções de ordem política, econômica, e normas de tradução.

- "Quomodo?", isto é, "como?" ou "de que maneira uma tradução é realizada?" é o tipo de pesquisa mais comum no campo da tradução, como afirma D'hulst (2010). Entretanto, o teórico explana que tal assertiva refere-se especificamente à investigação da prática e das normas tradutórias, não contemplando as reflexões acerca da tradução e o processo de formação de tradutores, bem como a institucionalização dessa formação.

- "Quando?" é uma pergunta que se refere a questões como as origens da tradução, em que momentos da história esse fenômeno foi observado, como categorizar esses momentos ou períodos ao longo do tempo, entre outras indagações. Além disso, D'hulst (2010) destaca que dedicar-se ao estudo da história não é meramente investigar fenômenos passados, porquanto história também significa mudança: algumas ideias, técnicas ou normas se alteram rapidamente, enquanto outras se mantêm imutáveis por períodos duradouros.

- Por fim, "Cui bono?" ou "com qual efeito?" sugere uma investigação enfocando os efeitos da tradução e seu papel dentro de uma dada sociedade, analisando os fatores de aceitação e influência naquele contexto. D'hulst lembra que as traduções operam em redes complexas, sendo parte de estruturas ou sistemas de mediação mais amplos (2010, p. 403).

Dessa forma, vale reiterar que a análise que proponho neste trabalho visa responder a algumas das indagações propostas por Lieven D'hulst (2010), como por exemplo "Quis?", uma vez que se compreende que falar da figura do tradutor muito contribui para um estudo historiográfico das traduções, motivo pelo qual objetiva-se aqui dar a conhecer os tradutores brasileiros que se dedicaram à tarefa de traduzir os sonetos de Shakespeare. Ademais, esta dissertação busca descrever os elementos resultantes das perguntas 
“Quomodo?", enfocando as estratégias tradutórias globais empregadas pelos diferentes tradutores, e também, "Cui bono?", procurando verificar os efeitos das diferentes traduções e o status que elas ocupam no contexto das traduções de sonetos. Dessa forma, pretende-se contribuir para a investigação sobre a difusão do soneto shakespeariano no Brasil e para futuras pesquisas que tomarem como base tal tema.

Retomando os questionamentos de D'hulst (2010) que atestam a relevância dos estudos historiográficos para o campo da tradução - de que maneira a tradução pode servir para a compreensão histórica, política, social etc., de uma dada cultura? Ou, como a história pode auxiliar a compreensão da atividade tradutória? - Anthony Pym (2014), em Method in Translation History, tende a orientar sua pesquisa sob a primeira ótica, quando afirma que a história da tradução se refere ao conjunto de discursos que analisam as mudanças ocorridas ou efetivamente impedidas de ocorrer no campo da tradução e que abrange as ações, os efeitos, os agentes, as teorias e os aspectos concernentes à tradução. Nesse sentido, é por meio da análise desses elementos e dos discursos provenientes de suas análises que se torna mais clara a compreensão histórica do campo disciplinar.

Pym (2014) identifica três áreas interdependentes de investigação no campo historiográfico: a arqueologia da tradução (Translation archaeology); a crítica histórica (Historical criticism); e explicação (Explanation). A primeira corresponde ao conjunto de discursos preocupados em responder, parcial ou integramente, à complexa questão de quem traduziu o quê, onde, como, quando, com que efeito e para quem. Esse tipo de investigação, que corresponde em parte às questões levantadas por D'hulst (2010) e já apresentadas neste trabalho, pode produzir desde a compilação de catálogos até a realização de pesquisas biográficas sobre tradutores - como se verá neste estudo. Trata-se, como ressalta Pym (2014, p. 5), de um trabalho potencialmente de grande utilidade para diferentes áreas da história da tradução. Por sua vez, a crítica histórica diz respeito ao conjunto de discursos que avaliam de que forma as traduções ajudam ou dificultam o progresso, 
sendo que antes de mais nada é preciso definir o que se entende por "progresso". A expectativa em relação a uma crítica histórica é que determine o valor de um trabalho de tradução feito no passado considerando os efeitos atingidos à época, em vez de avalia-lo à luz de valores contemporâneos. Por fim, a explicação (Explanation), que visa responder à pergunta por quê? trata de analisar o porquê de os fenômenos descritos por uma perspectiva arqueológica ocorrerem em momentos e lugares específicos. Enquanto a arqueologia e a crítica histórica se preocupam mais com fatos e textos, a explicação se volta para a causalidade, sobretudo para aquela que é afetada por relações de poder. É nesse campo que os tradutores podem ser vistos como atores efetivos na sociedade (PYM, 2014, p. 6). O estudioso vai além, afirmando que "por quê?" é a pergunta mais importante, por ser a única que leva em conta adequadamente os processos de mudança. Uma história que ignora a causalidade poderá conseguir descrever ações e efeitos, e até mesmo ter uma ideia unidimensional de progresso, mas não será capaz de reconhecer a dimensão humana nos documentos e ações como progresso de mudança (ibid.).

Buscando situar esta dissertação ainda melhor, e complementando o que foi salientado pelos estudiosos acima, o trabalho empreendido aqui também se movimenta de acordo com as concepções e questões de pesquisa evidenciadas pelo estudioso espanhol José Antonio Sabio Pinilla no que concernem aos estudos historiográficos sobre tradução no Brasil. Elas foram apresentadas em seu artigo sob o título de "A história da tradução no Brasil: questões de pesquisa" (2020), no qual o estudioso se detém sobre as diferenças conceituais entre os termos história e historiografia expondo a perspectiva de três estudiosos: Jean Deslile; José Lambert e Lieven D’hulst (respectivamente, 2008; 1993 e 2010 apud PINILLA, 2020) e, por fim, orienta aquilo que julga necessário ao historiador da tradução levar em consideração durante a sua pesquisa. Nesse viés, Deslile (2008 apud PINILLA 2020) assinala três sentidos para historiografia: a arte de escrever história; a compilação de obras produzidas em um determinado tempo ou em uma 
disciplina específica; e a perspectiva histórica dessa produção, cujo objetivo se pauta na evolução dos métodos de investigação do historiador e nas maneiras de se produzir a história. Por sua vez, Lambert (1993 apud PINILLA 2020) aponta que história se relaciona sobretudo com o material histórico, estando a historiografia associada diretamente ao discurso do historiador. $O$ terceiro autor citado por Pinilla (2020), nesse caso, D'hulst (2010 apud PINILLA, 2020), define história como sequência de eventos, ideias e discursos; e historiografia como a história das histórias; e ainda acrescenta um novo nível, a metahistoriografia,

que se refere à reflexão explícita sobre os conceitos e métodos de escrita da história, bem como a problemas epistemológicos e metodológicos relacionados a esses conceitos e métodos que têm a ver com questões espaciais, temporais, ideológicas e do acesso a fontes e a sua interpretação (p. 15)

Dessa maneira, Pinilla (ibid.) aponta algumas noções metodológicas que devem nortear o trabalho do historiador da tradução: a) despojar-se dos preconceitos e conhecimentos do presente ao desenvolver investigações historiográficas; b) relacionar sua interpretação de fatos passados com o respectivo tempo e contexto que ocorreram; c) pesquisar as condições de criação e recepção das traduções, bem como o status social da mesma e a função dos agentes e tradutores dentro de seus contextos históricos e sociais; e, por fim, d) apresentar, sempre que possível, uma periodização própria do estudo historiográfico da tradução. Sendo assim, ao se abordar os tradutores e as traduções dos sonetos de Shakespeare para o português do Brasil, este trabalho também levará em conta tais formulações assinaladas por Pinilla (2020).

Observa-se que o pesquisador espanhol também levanta alguns questionamentos importantes ao realizar o seu recorte, delimitando como escopo a história da tradução no Brasil. Nesse sentido, a categoria "Brasil" compreende uma amplitude de relações histórico-culturais complexas, ensejando as seguintes indagações: como relacionar a história da tradução no Brasil com outras categorias espaciais como Ibero-América, América Hispânica, América Latina e Hispânico-América? Há que se levar em conta 
sua conexão com Portugal, como América Portuguesa? Por esse prisma, o autor pontua que estudar ou historiar a tradução brasileira exige uma reflexão sobre a sua origem lusitana. Embora Pinilla (2020) creia que certamente seja relevante refletir acerca das relações entre Brasil e Portugal, principalmente no que tange à sua história de constituição como nação e como a tradução estava imbricada nessa conjuntura histórica ${ }^{6}$, o que se propõe aqui é o estudo das traduções dos sonetos shakespearianos publicados no Brasil sob uma perspectiva diacrônica, sendo o marco inicial os quatro sonetos traduzidos por Fontoura Xavier em 1905, quando essa forma poética já estava bem estabelecida no sistema literário brasileiro.

Além disso, Pinilla (2020) relata que, dentre as sugestões de estudos cronológicos, a história dos tradutores, a história do pensamento tradutório e o papel das traduções são temas que certamente integrariam o campo dos estudos historiográficos sobre a tradução no Brasil. No campo disciplinar da Tradução se entende por história dos tradutores pesquisas que abordam especificamente o profissional da tradução - seja no âmbito individual, coletivo ou de uma mesma geração, como, por exemplo, os tradutores do Modernismo, dos teóricos da tradução, ou até mesmo a relação entre os filólogos e a tradução. Por sua vez, a história do pensamento tradutório estaria vinculada aos conceitos e terminologias referentes ao ato de traduzir e interpretar. Já o estudo do papel das traduções versaria especificamente sobre a recepção e função dos textos traduzidos para o português do Brasil, bem como as mudanças e efeitos por eles provocados, de natureza quer estética, cultural ou ideológica, entre outras. O estudo que se apresenta aqui se insere na primeira vertente apontada por Pinilla, que, por sua vez, converge com a pergunta Quis? de D’hulst (2010), já que enfoca os diferentes tradutores dos sonetos de Shakespeare dentro do sistema literário brasileiro, procurando identificar suas concepções e estratégias tradutórias e buscando possíveis efeitos ou influências de suas traduções no contexto literário em que se

6 WYLER (2003) trata desse assunto no capítulo "A tradução na corte" de seu volume Línguas, poetas e bacharéis: uma crônica da tradução no Brasil. 
inserem, ou mesmo o inverso, possíveis impactos dos movimentos literários sobre essas traduções.

A perspectiva descritivista assumida para este trabalho é a postulada por Theo Hermans em seu texto introdutório à coletânea The Manipulation of Literature (1985), no qual o teórico apresenta essa abordagem como contraponto a um cenário caracterizado por: status marginal da literatura traduzida, crítica literária de ênfase avaliativa, conceito predominante de tradução como reprodução do original, predomínio de abordagens tipicamente prescritivas desde as primeiras reflexões sobre tradução e limitações da linguística para analisar traduções literárias. $O$ autor indica duas concepções que levam as traduções a ocuparem um lugar de desprestígio na tradição literária, a saber: uma visão romântica de autoria, conferindo ao produtor do texto de origem o estatuto de "gênio artístico", e uma noção muito restrita do que constitui uma "literatura nacional", deixando de fora a literatura traduzida e seu potencial de interação. Dessas concepções deriva a crença da criação literária como produto intocável e inimitável; e se a língua é concebida como fenômeno associado à ideia de nação e ao espírito nacional, os textos considerados canônicos de uma dada literatura também se revestirão de um caráter inviolável e sacro (HERMANS, 1985, p. 7). Portanto, qualquer tradução seria sempre um ultraje ao sagrado e, assim, condenada ao insucesso ${ }^{7}$.

A consequência da visão de que as traduções literárias são utensílios marginais de caráter secundário e desvalorizado só reforça a posição soberana e íntegra de um texto original. Em vista disso, Hermans apresenta um caminho alternativo que tem como base o modelo desenvolvido por Itamar Even-Zohar (1990, 1997 e 2005) que concebe a literatura como um

\footnotetext{
7 É importante ressaltar que, desde os anos 1980, quando Hermans produziu seu texto, as visões sobre tradução se ampliaram e diversificaram, devido a fatores como, por exemplo: (i) a propagação de uma epistemologia pós-estruturalista na academia, desafiando as tradicionais perspectivas essencialistas e prescritivas; e (ii) a consolidação da disciplina Estudos da Tradução em termos globais, com amplo florescimento no Brasil, onde cada vez mais surgem cursos de formação de tradutores e programas de pós-graduação voltados para pesquisas na área. Em que pese todo o interesse acadêmico despertado pela teoria e pela prática da tradução, pode-se dizer que houve poucas mudanças no que tange ao status do tradutor e à sua visibilidade. No Brasil, apesar dos prêmios anualmente concedidos aos tradutores, como o Jabuti ou o prêmio $A B L$ de Tradução, ainda não são muitas as pesquisas cujo foco recai sobre esses profissionais.
} 
polissistema, isto é, um complexo e dinâmico conjunto de elementos hierarquizados e interligados, sob a influência de fatores diversos e em constante estado de mudança. Nesses sistemas e subsistemas, os elementos centrais e periféricos estão em permanente tensão. Para Even-Zohar, qualquer modelo de polissitema literário deve incluir um sistema de literatura traduzida, já que a tradução costuma trazer inovação e mudança e interage com os demais cossistemas.

A abordagem que Hermans apresenta no texto de introdução à coletânea mencionada (1985) foi desenvolvida em meados dos anos 1970 por um grupo de pesquisadores europeus que procurou "estabelecer um novo paradigma para o estudo da tradução literária, com base em uma teoria abrangente e pesquisa em prática contínua"” (HERMANS, 1985, p. 10). Os pressupostos desses teóricos associados à abordagem dos estudos descritivos da tradução podem ser assim resumidos: uma visão de literatura como um sistema dinâmico e complexo; a convicção de que deve haver uma interação permanente entre modelos teóricos e estudos de caso; uma abordagem da tradução literária de caráter descritivo e voltada para o textometa, além de funcional e sistêmica; e um interesse nas normas e coerções que governam a produção e a recepção de traduções, na relação entre a tradução e outros tipos de reescrita, e no lugar e função da literatura traduzida, tanto em um dado sistema literário quanto na interação entre literaturas (HERMANS, 1985, p. 10-11).

De maneira distinta das abordagens mais convencionais que veem a tradução como um recurso secundário e, portanto, negligenciado, como já apontado neste capítulo, Hermans (1985) assinala que a proposta dos estudos descritivos é analisar a literatura sob um viés não prescritivista. Em vez de fornecer diretrizes de como produzir uma tradução, ou mesmo realizar algum juízo de valor sobre as traduções disponíveis postulando quando uma é precisa ou apropriada, enquanto outras são supostamente infiéis, a

\footnotetext{
8 "[Their aim is] to establish a new paradigm for the study of literary translation, on the basis of a comprehensive theory and ongoing pratical research". Vale dizer que todas as traduções de citações extraídas de obras de língua inglesa são de minha autoria, salvo quando se tratar de edição traduzida.
} 
abordagem descritivista observa o texto traduzido como uma produção resultante de fatores que agiram sobre ele, buscando ocupar um lugar sistêmico determinado no contexto receptor. Hermans (1985) explana ainda que essa postura implica automaticamente que o pesquisador irá tratar das traduções sem quaisquer noções pré-concebidas do que pode vir a ser "tradução", ou sem delimitar o que é ou o que não é tradução. Para os estudos descritivos, atribui-se o estatuto de "tradução" a todo texto que foi lido e aceito como tal por uma dada comunidade por algum período de tempo.

Considerando tais princípios concernentes à abordagem descritivista, o prisma desta pesquisa se configura segundo um viés mais funcional e pragmático, mapeando, analisando e detalhando os dados aqui trazidos sem exercer juízos de valor, ou seja, sem buscar avaliar se a tradução de um ou mais sonetos produzida por um dado tradutor é mais precisa - ou melhor - do que a elaborada por outro. Sendo assim, embasa-se na ótica proposta por Hermans de que "o resultado dessa nova abordagem a tradução é [...] uma ampliação considerável da perspectiva [...]", já que todo e qualquer fenômeno associado ao ato de traduzir se torna igualmente objeto de interesse de pesquisa (1985, p. 14).

Pym (2014, p. 14) salienta que a abordagem apresentada por Hermans (1985) viabilizou a aplicação de um modelo descritivo geral para estudar traduções, em vez de teorias (de tradução). No campo da historiografia, observam-se três impactos provocados por essa abordagem: o primeiro foi a elaboração de uma arqueologia empírica mais adequada, visto que a teoria dos polissistemas levou em conta estudos fragmentários concernentes a filologia e os inseriu em uma esfera mais ampla, ao unificar a história da tradução sem negar a profundidade histórica da própria disciplina; o segundo foi a explicação integrada (explanatory integration), posto que os arqueólogos sentiram-se chamados a elaborar suas próprias narrativas, em vez de se oporem a hipóteses que isolavam a perspectiva da arqueologia da tradução.

9 "The net result of the new approach to translation is [...] a considerable widening of the horizon [...]" (HERMANS, 1985, p. 14). 
Como os Estudos da Tradução passaram a se basear em corpora de traduções, houve o empenho em realizar pesquisas empíricas que visassem acolher, e não excluir, tais perspectivas arqueológicas. E, por fim, outra consequência foi a historicização de teorias que podem ser entendidas como desempenhando um papel em relação às práticas de tradução de sua respectiva época.

Vale ressaltar, contudo, que apesar de o modelo descritivista beneficiar o campo historiográfico da tradução, como se observa acima, Pym (2014) critica tal abordagem no que tange à figura do profissional de tradução, pois, segundo o estudioso, ainda assim a invisibilidade do tradutor é evidente, já que o foco recai mais no produto, enquanto o agente permanece em segundo plano. Para Pym, uma das diferenças entre uma teoria sistêmica consolidada e o campo da história dos tradutores - ainda a ser bastante explorado - é que a teoria presta pouca atenção aos tradutores, tratando-os como entidades abstratas e, não, seres humanos e individualizados, mas isso não os impede de poder dialogar de maneira produtiva.

Em se tratando da investigação acerca da historiografia dos tradutores, os estudiosos que atuam nesse campo precisam pensar nos tradutores enquanto pessoas (PYM, 2014), já que somente seguindo esse viés seria possível verificar a hipótese elaborada por Pym (2014, p. 160) de que os "tradutores são causas ativas efetivas, com suas próprias identidades e agendas como uma categoria profissional"10. Logo, o estudioso aponta a relevância de a historiografia dos tradutores não se limitar a investigar as atividades de tradução desses profissionais, mas também refletir sobre as outras esferas da sociedade em que tiveram uma atuação ativa. Em outras palavras, Pym (2014) mais uma vez convida seus leitores a pensar nos tradutores como seres humanos e sociais e, não, como seres passivos e estáticos. Segundo esse prisma, o estudioso faz algumas assertivas que, embora pareçam obviedades em um primeiro momento, têm por objetivo

10 "They [the translators] are active effective causes, with their own identity and agenda as a professional group." (p. 160). 
evidenciar a subjetividade do tradutor e o fato de que suas ações intervêm e produzem história: tradutores podem realizar mais que traduções; tradutores têm interesses pessoais; tradutores movimentam-se; e tradutores podem ter diversos nomes. Nesse sentido, esta pesquisa levará em conta tais afirmações durante a análise historiográfica dos tradutores dos sonetos de Shakespeare para o português do Brasil, mostrando na medida do possível onde tais profissionais atuaram e quais papeis desempenharam dentro da sociedade brasileira.

Outro ponto igualmente primordial ao se debruçar sobre a historiografia dos tradutores e suas respectivas traduções é a reflexão sobre retraduções e suas motivações, principalmente em se tratando de um autor canônico como Shakespeare. Lawrence Venuti, em sua obra de 2013 Translation changes everything: theory and practice, aborda o assunto no capítulo "Retranslation the creation of value", e inicia o texto estabelecendo distinções entre tradução e retradução. Segundo ele, a tradução é uma inscrição do texto de partida ajustada para atender a interesses da língua e da cultura receptora, mesmo quando o tradutor preserva uma correspondência semântica estrita e integra elementos do contexto cultural de origem. Já as retraduções são um caso especial, porque os valores gerados por elas estão duplamente associados ao ambiente receptor, circunscritos não apenas pelos valores de recepção que o tradutor inscreve no texto de partida, mas também por aqueles evidenciados em uma ou mais traduções anteriores. O estudioso ressalva, no entanto, que existem retraduções inspiradas unicamente no texto de origem e produzidas sem qualquer conhecimento de uma tradução pré-existente. Para Venuti (2013), tais diferenças tornam-se evidentes durante o processo de escolha de um texto a ser traduzido ou retraduzido, e se acentuam durante 0 desenvolvimento das estratégias discursivas em uma retradução, por exemplo. Salienta, ainda, que tanto a escolha de um texto como suas estratégias discursivas ocorrem conforme os interesses do profissional de retradução e das entidades que utilizarão e promoverão o texto retraduzido. Nesse sentido, exemplifica que uma obra shakespeariana, com seu status 
canônico no contexto receptor, certamente fomentará retraduções, já que uma amplitude de leitores na cultura de recepção estarão interessados em interpretá-la de acordo com seus próprios parâmetros e valores, que moldarão, consequentemente, outras estratégias de retradução. Entretanto, Venuti (2013) também ressalta que a decisão de retraduzir um texto, embora possa vir acompanhada da premissa de uma otimização textual, pode ser motivada por interesses editoriais que optam por investir em uma retradução visando lucrar pela simples comercialização do produto, sem maiores preocupações literárias ou acadêmicas.

Ainda acerca dos efeitos de uma retradução, Venuti (2013) dá como exemplo a Bíblia, pois suas inúmeras retraduções forjaram a hegemonia de interpretações institucionalizadas, nesse caso, a da Igreja. O caso da King James Bible (1611) - que consolidou a autoridade da igreja anglicana durante o início do século XVII - é um exemplo claro desse efeito, pois estava embasada em versões protestantes de tradutores ingleses precedentes. Ao mesmo tempo, o estudioso comenta que as retraduções podem desafiar uma visão hegemônica já estabelecida com o intuito de modificar sua ótica ou de conceber uma nova, como é o caso dos efeitos resultantes da interpretação protestante em relação à católica. Outro impacto que as retraduções podem ocasionar na cultura receptora é o da transformação de um texto considerado periférico em canônico, devido às diversas interpretações e à visibilidade que o texto ganhará. Nesse caso, as retraduções de textos marginais são provavelmente motivadas por uma agenda político-cultural em que uma dada ideologia direciona a escolha do autor ou o texto estrangeiro e a definição das estratégias tradutórias a serem empregadas (VENUTI, 2013, p. 27).

Martins (2019) elenca algumas outras motivações para a retradução constante de textos clássicos, como é o caso da poesia lírica de Shakespeare, citando, por exemplo, objetivos como atualizar uma tradução antiga que seguiu normas tradutórias, linguísticas e/ou editoriais consideradas ultrapassadas; explicitar a topicalidade de uma obra com alguma situação presente; aproveitar que um autor está em domínio público para oferecer suas obras em 
catálogo; substituir traduções anteriores consideradas "falhas" ou "ruins" por instâncias críticas. A estudiosa também ressalta o papel dos paratextos nas edições de textos retraduzidos, como será visto mais adiante no capítulo desta dissertação que enfoca as diferentes traduções e edições dos sonetos.

Segundo Martins (2019, n.p.), uma característica comum das retraduções é a presença de paratextos, que criam uma dimensão intertextual para o texto traduzido, estabelecendo uma rede de relações que envolve, de um lado, o texto e o contexto de origem, e de outro, o contexto de recepção em vários momentos de um eixo diacrônico. Os paratextos sinalizam o caráter de retradução do texto publicado (VENUTI, 2013) e muitas vezes explicitam a diferença entre a nova versão e as anteriores, ou mesmo a motivação do tradutor ou da editora para produzi-la.

Outro aspecto que faz parte das decisões do tradutor foi bem apresentado pelo estudioso e teatrólogo Jean-Michael Déprats citado por Françoise Massardier-Kenney no artigo intitulado: "Of forceful looking: New perspectives on retranslation" (2014). Ele afirma que, no que tange à retradução de textos antigos, como é o caso da poesia lírica e dramática de Shakespeare, o tradutor deve escolher entre a época da obra ou o momento da recepção do texto traduzido, ou seja, precisa optar por privilegiar o tempo do autor ou do leitor. Nesse sentido, Déprats defende que a tradução envolve uma estratégia necessária, mesmo que nem sempre consciente, que diz respeito à relação de alguém com a história de uma língua. Depráts considera um paradoxo recorrer a uma tradução arcaizante, que, ao recusar a "mentira" de traduzir transformando o velho em novo, tende a restringir o acesso à obra, tornando-a um mero trabalho de erudição que se distancia do seu contexto. Já a preferência pela tradução em uma linguagem mais contemporânea advém do anseio de estabelecer uma relação viva e familiar com o público, como é o caso de muitas traduções de peças de Shakespeare que buscam clareza e concisão por meio de recursos como um vocabulário simples e não literário (Massardier-Kenney, 2014, p. 304). Dessa maneira, ora um dado tradutor de Shakespeare poderá optar por uma tradução mais estrangeirizante 
preservando aspectos linguísticos mais arcaicos e, às vezes, eruditos; ora ele pode buscar a retradução de uma maneira mais contemporânea, lançando mão de uma estratégia mais aclimatadora, destacando mais elementos do ambiente receptor. 


\title{
3 \\ O TRAJETO DO SONETO: DE FRANCISCO PETRARCA A WILLIAM SHAKESPEARE
}

\author{
When in the chronicle of wasted time \\ I see descriptions of the afairest wights, \\ And beauty making beautiful old rhyme \\ In praise of ladies dead and lovely knights, \\ WILLIAM SHAKESPEARE (sonnet 106)
}

Neste capítulo objetiva-se primeiramente apresentar uma trajetória histórica do soneto, construindo uma narrativa acerca de eventos e poetas que contribuíram para a produção, inovação, subversão e difusão dessa forma métrica até a sua chegada à Inglaterra da época de Shakespeare. Não se pretende, contudo, discutir minuciosamente cada personagem ou acontecimento que afeta o soneto, mas sim traçar um breve panorama, de modo a compreender como é complexa a circulação do soneto no contexto da cultura elisabetana-jaimesca, que consequentemente irá reverberar na produção literária de Shakespeare, que soube utilizar essa forma poética de maneira singular. No capítulo posterior, que tem por foco especificamente os sonetos do Bardo publicados em 1609 por Thomas Thorpe (c. 1569 - c. 1625), o soneto shakespeariano será comparado e contrastado com os sonetos produzidos pelos demais poetas elisabetanos que o precederam, averiguando possíveis subversões no que tange ao conteúdo, à forma e à recepção.

Para essa tarefa escavadora, utiliza-se como referencial teórico o minucioso trabalho de Michael R. G. Spiller, na obra intitulada The development of the Sonnet - An introduction (1992). Embora não esgote o tema, Spiller (1992) se debruça de maneira bem atenta sobre a evolução e a jornada do soneto até o século XVII inglês. Recorreu-se também aos estudos de Katherine Duncan-Jones (1997), Peter Hyland (2002), Paul Edmondson e Stanley Wells (2004), Stephen Orgel (2006) em coautoria com G. Blackmore Evans e Harold Bloom (2008). Além disso, este trabalho põe em diálogo publicações de shakespearianistas brasileiros/as acerca do soneto, como é o caso da pesquisadora Luci Collin, que apresenta uma análise do soneto e esboça sua história em "O soneto shakespeariano" (2008); a dissertação de 
mestrado de Shanta Navvab Walker (2018), que tem por título Para uma tradução comentada dos sonetos de Shakespeare; e, também as análises de poetas que traduziram os sonetos de Shakespeare, a saber, Jorge Wanderley (1991), Péricles Eugênio da Silva Ramos (2008) e Elvio Funck (2019), que em seus prefácios abordam o soneto no contexto elisabetano e a publicação dos Shake-speare Sonnets em 1609.

Antes de se observar o trânsito dessa forma poética muito usada na Europa continental, bem como o seu desenvolvimento e a sua entrada na Inglaterra, se faz pertinente uma análise etimológica do vocábulo "soneto" e de sua composição inicial.

Palavra que deriva do italiano, sonetto (c. 1293) inicialmente era usado para referir-se a uma forma métrica que consistia em versos curtos e melodiosos. O provençal tem o vocábulo sonet derivado de son, que significa "som", originado do latim sonus, cujo sentido é "cançoneta" - uma forma de canção que acompanhava um poema (COLLIN, 2008). Spiller (1992) comenta que o soneto tem seus primeiros registros por volta do ano 1230 no sul da Itália, especificamente na Sicília, na época dos trovadores da corte do rei Frederico II. Esses artistas, que compunham uma estrutura que se aproximava das baladas provençais, geralmente estruturavam-na em uma oitava (oito versos) e dois tercetos (duas estrofes de três versos), que era acompanhada por duas melodias distintas: uma para a oitava e outra para os tercetos, dando origem ao que hoje se conhece por soneto. Embora em sua forma seminal o soneto não seguisse forma fixa alguma, sendo a disposição das rimas e o número dos versos aspectos variáveis, Collin (2008) salienta que Guittone D’Arezzo (c. 1230-1294) foi responsável por padronizar essa forma métrica, escrevendo 246 sonetos sobre temas variados, cuja composição passou a ter 14 versos. Posteriormente, com Francisco Petrarca (1304-1374), essa forma se fixará ainda mais, difundindo-se como um poema de onze sílabas métricas (hendecassílabos). Os versos estarão dispostos organizadamente em dois quartetos ou quadras, compondo a oitava (que ficou conhecida como a ottava rima) acompanhados de dois tercetos, formando um sexteto, portanto. 
Caracteristicamente, o conteúdo das quadras e dos tercetos é formado por antíteses e oxímoros ${ }^{11}$, isto é, os assuntos poderão ser contrastantes entre si, havendo possíveis elaborações de perguntas nas quadras que, no sexteto, virão a ser respondidas, ou fatos passados aludidos na oitava que serão contrapostos no sexteto, que apresentará os eventos do presente.

Ao se refletir sobre soneto e sua gênese, certamente a figura de Francisco Petrarca deve ser evocada como um grande contribuidor e propagador dessa forma métrica hoje tão consagrada. Portanto, é pertinente salientar, seguindo Michael Spiller (1992), que Francisco Petrarca produziu uma das obras líricas mais complexas e importantes da Europa: o famoso Canzoniere (O Cancioneiro), composto por 317 sonetos, 29 canções, 7 baladas e 4 madrigais, inspirando um modelo de expressão do amor poético ${ }^{12}$ por toda a Europa Renascentista. Portanto, é partindo desse poeta que tanto influenciou a forma lírica "soneto" que este trabalho configura o seu trajeto, sem deixar de reconhecer, contudo, que esse modelo poético já havia sido concebido na Itália do século XII. Isso significa dizer que são considerados os precursores conterrâneos de Petrarca, dentre eles, Guittone D’Arezzo, que introduziu essa forma parcialmente fixa, como já mencionado acima; Dante Alighieri (1265-1321), que publicou o livro Vita Nuova em 1293, que além de engrandecer a figura da mulher amada sob o nome de Beatriz, a imortaliza em seus poemas - elementos muito similares aos que Petrarca produziu posteriormente em seus sonetos; e Guido Cavalcante (c. 1255-1300) que se associou à prática de produção de sonetos e ajudou a desenvolver o modelo Dolce Stil Nuovo (COLLIN, 2008). Crê-se, portanto, neste trabalho, que os poetas italianos aqui trazidos exerceram alguma influência nos sonetos que Petrarca veio a desenvolver. Seja em menor ou maior grau, assim como os antecessores de Shakespeare "preparam o terreno" para posteriormente

\footnotetext{
${ }^{11}$ Entende-se antítese como uma figura de linguagem que aproxima palavras, frases ou orações com sentidos opostos, geralmente ligados por coordenação sintática; oxímoro ou paradoxo, por sua vez, estabelece-se a partir de um único enunciado com pensamentos antagônicos. Essas figuras de estilo, sobretudo a antítese, advêm dos antigos cancioneiros e do petrarquismo. (MOISÉS, 2004, p. 31)

12 Petrarca e até seu conterrâneo Dante concebem em seus sonetos a ideia do amor poético de maneira mais restrita do que os sonetistas ingleses que o compreendem por sentido mais amplo. Tais concepções serão detalhadas posteriormente.
} 
ele produzir seus sonetos, lançando mão de recursos estilísticos e formais disponíveis, para o poeta italiano não se entende o contrário.

Com o epíteto de "tecelão dos versos de amor" (SPILLER, 1992), o poeta, humanista e diplomata italiano Francisco Petrarca se apresenta em um momento de transição da ldade Média para o Renascimento, um período no qual a literatura italiana dava seus primeiros passos ${ }^{13}$. A língua utilizada na difusão do conhecimento e na circulação de informações oficiais era o latim, e embora Petrarca tivesse o italiano como língua nativa e fosse competente no provençal, produziu a maior parte de seus trabalhos em latim. Sua obra mais famosa e influente, no entanto, foi escrita em italiano. Petrarca foi um poeta de múltiplas faces, de variados "eu líricos", todos moldados a sua maneira de se expressar em cada fórmula poética. Em seus sonetos, muitas vezes a face revelada é a de um apaixonado que eleva a figura da mulher, sua amada, ao mais alto grau, sendo em determinado momento entendida como um ser dual, que ora é terreno, ora é celestial. Essa fórmula poética, que ocupa 317 vezes um lugar em sua obra mais famosa, o já mencionado Canzoniere, não é objeto de sua criação, como já salientado, entretanto, se tornou sua criatura, cuja estrutura, embora breve, foi capaz de exibir um "eu" complexo, variado e de riquezas incontáveis (SPILLER, 1992).

A despeito de variantes historicamente estabelecidas, o soneto é a forma poética mais duradoura do chamado cânone ocidental, e Petrarca soube bem utilizar a característica breve dessa estrutura, acentuando o seu caráter objetivo e imediato. Esses aspectos formais, ao mesmo tempo que resolvem o problema de extensão e proporção, prescrevendo uma forma métrica matriz de catorze versos para o pensamento do poeta, podem ser bastante desafiadores, uma vez que testam sua liberdade criativa, impelindo-a a se adequar a um molde pré-existente.

Em termos de estrofação e de esquema rímico, vale um breve resumo acerca do seu desenvolvimento. Na época de Petrarca o soneto era composto

\footnotetext{
${ }^{13}$ Levando em consideração, evidentemente, a unificação nacional do país alcançada somente ao longo do século XIX, e que tem na figura do Conde Cavour seu personagem mais decisivo.
} 
por dois quartetos e dois tercetos, e nas rimas esperavam-se as seguintes combinações: $a b a b$ abab ou abba abba, sendo o terceto composto por duas ou três rimas que seguiam: $c d c d c d$; cde cde, e esse estilo perdurou por três séculos. Observa-se que o soneto petrarquiano, que foi difundido pelo continente europeu, não se caracterizava pelo recurso conclusivo concentrado no dístico final utilizado pelos poetas ingleses. Foi em 1525 que Sir Thomas Wyatt (1503-1542) optou ${ }^{14}$ pela alteração do desfecho do soneto, que viria a se tornar modelo para os futuros sonetistas ingleses.

Vale salientar que Wyatt não buscou grandes inovações formais em seus trabalhos, mas inicialmente se deteve na tradução de sonetistas italianos, passando a observar a estrutura e o estilo italiano para a composição de seus poemas. Sendo assim, uma vez que a forma petrarquiana é importada por Wyatt, recebe influências anglófonas por meio de Henry Howard (1517-1547), conhecido como Conde de Surrey, que altera o esquema rímico do soneto e o padrão de versificação para três quartetos e um dístico ( $a b a b$ cdcd efef $g g$ ), cujo ritmo vem a ser o pentâmetro iâmbico. Foi essa mudança, principalmente, que gerou o formato básico adotado pelos sonetistas ingleses, inclusive Shakespeare, que o utilizou praticamente em quase todos os seus sonetos, como será visto em mais detalhes posteriormente.

Em sua coletânea Canzoniere, Petrarca selecionou e ordenou os sonetos e poemas, considerando esse trabalho como "rimas esparsas" ou, como se observa no título em latim, Rerum vulgarium fragmenta (pequenos nadas, em língua vulgar), apesar de ter buscado corrigi-lo e nele trabalhar ao longo de toda a sua vida, desde que começou a produzi-lo, em 1330. Possivelmente, o título "rimas esparsas" ou até mesmo "fragmenta" tem seu fundamento no fato de que seus sonetos e poemas tiveram espaços de tempo consideráveis para serem produzidos, como é o caso do primeiro soneto da

\footnotetext{
14 Wyatt "optou" e não "criou" o dístico conclusivo, pois como se verifica na nota de rodapé de Spiller (1992), Nicolò de'Rossi (c. 1285-1335), poeta italiano, já havia lançado mão desse recurso em seus sonetos séculos antes, escrevendo-os na forma abba abba cdc dee. Todavia, como a forma difundida na Europa foi a petrarquiana, não se tinha uma conclusão em dístico. Por esse motivo, os poetas ingleses apenas reinventaram esse recurso, ao optar pelo desfecho em forma de dístico.
} 
obra, o soneto prefatório ${ }^{15}$ (SPILLER, 1992, p. 46), que foi escrito em 1350, embora, como mencionado, Petrarca já houvesse começado a escrever sonetos em 1330.

Grande parte das produções que estão dispostas em Canzoniere tem foco central no amor por Laura, personagem criada a partir das experiências da vida privada do próprio poeta italiano, segundo estudiosos como Spiller (1992), Hyland (2002) e Oliveira (2010). Seguindo esse viés, a obra se divide em dois eventos predominantes: "Em vida de Laura" e "Em morte de Laura", construindo-se a partir de sentimentos e emoções que o poeta tem pela sua amada. Vale frisar que a obra não se detém apenas nos versos sobre o amor: "Mas o amor não é a única temática do soneto, assim como não era para Petrarca"16 (SPILLER, 1992, p. 1); o que significa dizer que essa forma métrica, de modo geral, tem uma abrangência muito mais ampla do que apenas exprimir o amor poético. Apesar de os sonetos de Petrarca, em sua maioria, evocarem o amor, o poeta produziu poemas de amizade e de temática civil, que foi aclamada posteriormente por poetas italianos românticos, por conta do seu teor saudosista e patriótico. Além disso, salienta-se aqui que, de igual maneira, Shakespeare utilizou dos sonetos para falar de temas diversos como política, amizade, amor, natureza, a nomear alguns. É evidente que Petrarca trata os seus sonetos de maneira singular, apresentando uma coerência criativa ${ }^{17}$ na sua composição, sendo fluido e objetivo, sobretudo no que tange à referência que faz quase sempre ao mesmo objeto, Laura, elemento que em grande medida unifica seus sonetos, e aquela que merece todo o seu amor, seja em vida ou em morte. Entretanto, críticos afirmam que o escritor italiano adota uma postura antagônica, ou instável, uma vez que lança mão da figura de linguagem antítese, que caracteriza o seu estilo de escrita e até seu modo de pensar (SPILLER, 1992). Isso pode se dar, talvez,

\footnotetext{
15 "prefatory sonnet" (p. 46).

16 "But love is not the only occupation of the sonnet, nor was it for Petrarch himself" (p. 1).

17 Entende-se por "coerência criativa" o que Petrarca veio a desenvolver por uma instabilidade que é resolvida na "volta" a oitava. Ou ainda, o que compreendeu Spiller (1992) sobre a escrita petrarquiana "a inclusão de uma experiência narrada que é desmembrada em outras camadas [...] mantendo sutilmente um desenvolvimento e coerência" (p. 49)
} 
devido à ideia que Petrarca tem do soneto como fenômeno momentâneo, cuja forma poética funciona como um facilitador para a narração de experiências. Oliveira (2010), em seu estudo, apresenta o soneto 47, em italiano, seguido da tradução do poeta e tradutor Jamir Almansur Haddad:

Soneto 47

Benedetto sia 'I giorno, e 'I mese, e l'anno, e la stagione, e 'I tempo, e l' ora, e 'I punto, e 'l bel paese, e ' l loco ov'io fui giunto da' duo begli occhi, che legato m'hanno;

e benedetto il primo dolce affanno ch'i' ebbi ad esser con Amor congiunto, e l'arco, e le saette ond'i' fui punto, e le piaghe che'n fin al cor mi vanno.

Benedette le voci tante ch'io chiamando il nome de mia donna ho sparte, e i sospiri, e le lagrime, e 'I desio;

e benedette sian tutte le carte ov'io fama l'acquisto, e 'I pensier mio, ch'è sol di lei, sì ch'altra non v'ha parte.

Bendito seja o dia, o mês, o ano, A sazão, o lugar, a hora, o momento, E o país de meu doce encantamento Aos seus olhos de lume soberano.

E bendito o primeiro doce afano Que tive ao ter de Amor conhecimento 
E o arco e a seta a que devo o ferimento,

Aberta a chaga em fraco peito humano.

Bendito seja o mísero lamento

Que pela terra em vão hei dispersado

E o desejo e o suspiro e o sofrimento.

Bendito seja o canto sublimado

Que a celebra e também meu pensamento

Que na terra não tem outro cuidado.

Sob minha própria análise, o soneto aqui apresentado contém elementos que corroboram com o que foi afirmado anteriormente, como a narração de um momento da vida do poeta, nesse caso, a circunstância em que se apaixona por sua amada, por exemplo. Para tanto, inicia bendizendo a tudo aquilo que envolve e viabiliza o despertar desse amor. Por outro lado, dá graças, ou mesmo abençoa, aquilo que Ihe faz doer por consequência desse amor, desde a "flechada" que recebeu e que o feriu, até o seu sofrimento que surge por conta dessa "ferida aberta". Isso causa uma sensação contraditória e de instabilidade, pois cria uma expectativa que não se sustenta até o final do poema. Verifica-se, portanto, uma oposição de ideias sobre um mesmo referencial, que neste caso é o surgimento do amor por Laura, estabelecendo, assim, um paradoxo. Já em relação à figura de linguagem antítese não há evidências, seja em decorrência de uma opção tradutória - tendo o tradutor preferido reproduzir a imagem contraditória em detrimento de vocábulos que geram oposição, mas que referenciam objetos distintos - seja pelo fato de o soneto não a apresentar no original. Em contrapartida, verifica-se no soneto 104 o trecho no qual é notório o emprego da antítese como recurso de destaque da instabilidade do soneto petrarquiano, como também acredita Oliveira (2010), ilustrado aqui no original e na tradução de Jamir Almansur Haddad: 
e volo sopra 'I cielo, e giaccio in terra;

e nulla stringo, e tutto 'I mondo abbraccio.

E vôo para o céu e desço à terra;

E nada aperto e todo o mundo abraço.

No trecho em questão, há ocorrência de antítese em dois momentos: nos vocábulos cielo (céu) e terra; nulla (nada) e tutto (tudo), que na solução tradutória veio a ser "todo".

Essa postura antagônica tanto psíquica quanto forma retórica, já salientada por Spiller (1992), causa um movimento de instabilidade que domina os sonetos petrarquianos. Para Hyland (2002), esse movimento é quase que dialético, uma vez que há na estrutura dos sonetos um discurso de ideias ou vocábulos opostos, que podem vir a se contrapor. Essa estrutura a qual Hyland (2002, p.127) chama de unequal two-part structure (estrutura de duas partes desiguais) é o movimento das quadras para os tercetos que pode se desenrolar na "observação e conclusão" ou na "declaração e em um contra-argumento" (ibid.), e que atua como um recurso essencial dentro do estilo petrarquiano. Hyland (2002) explica ainda que a oitava apresenta uma ideia ou posição, mas que após o oitavo verso há um turn (volta) e, então, geralmente no sexteto, há uma resposta ou uma "reviravolta" no argumento presente na oitava.

Após a morte de Petrarca, em 1374, o soneto permanece sob o domínio italiano ainda por mais 16 anos, não se consolidando em nenhuma outra cultura. Há evidências, contudo, de um primeiro contato dessa forma métrica com escritores estrangeiros. Spiller (1992) destaca duas figuras possíveis: o escritor inglês Geoffrey Chaucer (c. 1343-1400) e o espanhol Inigo Lopez de Mendoza (1398-1458), conhecido como Marquês de Santillana. O primeiro limitou-se apenas a traduzir um soneto (Rime 132), que incluiu em seu longo poema narrativo, Troilus and Criseyde (Tróilo e Créssida), como será visto logo 
adiante; o segundo produziu no espanhol sonetos à moda italiana, logo, seguiu os aspectos formais, produzindo 42 sonetos. Sendo assim, é possível atribuir a esses dois poetas as primeiras produções de sonetos fora da ltália, sessenta anos após a morte de Petrarca. A partir desse evento, Spiller (1992) comenta que houve um hiato temporal que se estendeu até 1520, quando o soneto de fato se estabeleceu na Espanha, França, Inglaterra e Alemanha ${ }^{18}$.

No que se refere ao escritor inglês Chaucer, vale destacar o que diz Anthony Burgess (1999): "um dos mais bem equipados poetas ingleses" (p. 39). Embora não tenha sido um aristocrata desde seu nascimento, Chaucer trabalhou como cortesão, diplomata e funcionário público e teve a oportunidade de estudar artes, ciências e as literaturas francesa e italiana. Foi autor de obras canônicas como The Canterbury Tales (Os contos de Canterbury) e o conto de amor de Tróilo e Créssida em versos, onde consta a sua tradução do soneto 132 de Petrarca, o qual Spiller (1992) assevera ser traduzido sem preservar o formato de 14 versos do soneto italiano. Apesar de as duas estrofes terem sete versos cada, Chaucer rimou em um esquema conhecido como "rima real" (ababbcc), aparentemente introduzido na poesia inglesa por ele (HYLAND, 2002, p. 96).

Por sua vez, o escritor espanhol Inigo Lopez de Mendoza, Marquês de Santillana, era homem da corte, cuja cultura recebeu bastante influência da Itália, embora ambas as monarquias estivessem em constantes discordâncias durante o século XV, devido à luta por domínio territorial na península itálica. Esse atrito tanto político quanto militar fazia com que Espanha, França e Itália estivessem permanentemente em conflito. Mas, apesar disso, havia também muito contato entre os países. Spiller (1992) comenta que os governadores de Aragão, de quem o Marquês era aliado, tiveram uma base militar em Nápoles por muitas décadas. Nesse convívio, o modelo de soneto italiano passa para o vernáculo espanhol e se torna a forma de expressão da sociedade cortesã

\footnotetext{
18 Conforme a nota de rodapé de Spiller (1992), a difusão dos sonetos se iniciou primeiramente na Espanha entre os anos de 1438 e 1458 por intermédio do Marquês de Santillana; depois na França em 1529 por Clément Marot; posteriormente, em 1525 na Inglaterra por Sir Thomas Wyatt e na Alemanha em 1624 por Martin Opitz.
} 
espanhola, que passou a utilizar essa forma poética para enaltecimento, louvor e como meio de exteriorizar o amor. Sobre essa comunidade da elite espanhola em que o soneto transitou, vale salientar que "nem todos os cortesãos produziam sonetos, mas a partir de meados do século 15 , essa estrutura passou a ter uma vinculação estreita com a cultura da corte e a representar a voz desta" (SPILLER, 1992, p. 66) ${ }^{19}$. Dessa maneira, observase que o soneto integrou a cultura da corte por muito tempo, sendo uma forma de entretenimento da elite e, também por vezes, um meio de narração de eventos ocorridos nesse ambiente. É possível verificar essa característica até na Inglaterra da época de Shakespeare, onde a circulação dos sonetos se dava por meio de manuscritos entre membros da corte, ou amigos próximos, assegurando assim sua exclusividade, consoante Hyland (2002). Vale mencionar que Santillana, inicialmente, visou apenas produzir sonetos observando a forma italiana, como se vê no título de sua obra que se apresenta como Sonetos fechos al italico modo (sonetos feitos no estilo italiano). As evidências, portanto, são de que os sonetos italianos não foram traduzidos do italiano para o castelhano mas, sim, escritos diretamente em castelhano seguindo o formato italiano, introduzindo o hendecassílabo na poesia espanhola, na qual predominava o verso octossilábico. Já no caso do inglês Chaucer, em Tróilo e Créssida há a ocorrência da tradução do soneto italiano, e são nessas duas figuras que se tem registro das primeiras produções do soneto fora do território italiano.

Segundo o bibliógrafo francês Hugues Vaganay (1899 apud SPILLER, 1992), o século XVI é considerado o século do soneto, uma vez que se estima um grande fluxo de produção e tradução dessa forma métrica dentro do continente europeu. Na Itália, França, Inglaterra e Alemanha registram-se cerca de três mil poetas produzindo uma média de duzentos mil sonetos, marcando assim o período entre 1530 a 1650 como a época de efetiva difusão e desenvolvimento do soneto. Para Hyland (2002) é nesse período que a

19 "Not all courtiers wrote sonnets, but from the mid-fifteenth century onwards the sonnet was very closely linked to court culture and to the presentation of a courtly voice" (SPILLER, 1992, p. 66). 
forma poética chega à França e à Inglaterra, bem como à Alemanha; no caso da Espanha, essa estrutura já havia se fixado durante o século $X V$, tendo os poetas espanhóis Garcilaso de la Vega (1539-1616) e Juan Boscán (14901542) os mais atuantes do século XVI, como afirma Franco (2007); em Portugal, o soneto foi introduzido durante esse período, por intermédio de Sá de Miranda (1481-1558), Dom Manuel de Portugal (1516-1606) e Luiz Vaz de Camões (1524-1580), entre outros.

Foi por meio do processo de imitatio (imitação) que tradutores e poetas buscavam importar os sonetos italianos para suas culturas, como observam Franco (2007) e Spiller (1992). Esse foi o principal recurso responsável pela difusão do soneto e de outras formas literárias por toda a Europa. Nesse processo não havia a pretensão de se alterar os elementos formais dispostos no original; pelo contrário, tinha-se uma estrita observância e correspondência com a obra da língua de partida. Além disso, a concepção de imitatio era embasada pelo hibridismo poético. Sobre esse fenômeno vale citar o que afirma Franco (2007):

O hibridismo poético caracteriza os primórdios da aventura de introdução das formas italianas na poesia escrita em língua portuguesa, na virada entre os séculos XV e XVI. Isto é, ao introduzirem as formas e os gêneros italianos (o soneto, a sextina, a canção e também aquelas formas mais reflexivas e clássicas como a ode, a elegia, a carta moral e a écloga pastoril) os primeiros quinhentistas continuaram a lançar mão do hibridismo poético praticado na tradição cancioneiril, que há um século se humanizava na corte central do cenário ibérico, isto é, em Castela, quer quando trovavam em castelhano, quer quando em português (p. 72).

Sendo assim, reitera-se a importância da imitatio dentro do contexto de difusão de formas poéticas e literárias, principalmente em Portugal, embora Spiller (1992) já tenha salientado que esse processo é evidente dentro de todo o âmbito literário europeu.

No início do século XVI, o soneto chega à Inglaterra - principal objeto de análise desse percurso - de Henrique VIII (1509-1547). Entre os seus adeptos, encontra-se a figura do já mencionado Sir Thomas Wyatt (15031542), que além de homem da política e da diplomacia atuou como escritor, 
tradutor e poeta. Wyatt foi o responsável por introduzir o soneto na Inglaterra do século XVI, logo após uma visita à Itália em 1527 (COLLIN, 2008). O poeta inglês, além de traduzir os sonetos italianos para o seu vernáculo, observou a estrutura e o estilo composto na língua de partida. Contudo, compreende-se que ele tenha sido o primeiro a inovar tal forma métrica, que mais tarde se constituiria como o "soneto inglês" - ou, conforme Burgess (1999, p. 120) afirma, "Wyatt foi o primeiro a escrever os sonetos ingleses.".

Apesar de manter a divisão entre as oitavas e sextetos, uma das marcas do soneto petrarquiano, Wyatt introduz no último terceto um dístico que viria a alterar o desenvolvimento argumentativo do estilo italiano, que se constitui por um movimento de contraposição quase dialético, como salientado por Hyland (2002) e mencionado anteriormente aqui. Essa volta que o sexteto realizava à oitava foi desconstruída ao se adotar o esquema de dístico no final, que estabelecia uma estrutura lógica de desfecho, conferindo assim um caráter conclusivo. Segundo Hyland (2002), esse foi o primeiro passo para o desenvolvimento do soneto inglês.

Spiller (1992) destaca que o dístico tem uma função proverbial, afirmando que, seja ele alocado no final ou em qualquer parte do soneto, aqueles versos manifestam uma reflexão sensata, como uma máxima ou provérbio, ou, como os estudiosos da retórica consideram, um aforismo ou apotegma. Nesse prisma, confere-se ao dístico um caráter de autoridade, ou seja, esse recurso é utilizado para estabilizar ou controlar um fato ou sensação dúbia dentro de um discurso, nesse caso, recorrendo a uma expressão sensata de compreensão mais direta e equilibrada. Sendo assim, ao lançar mão de tal recurso, o poeta apela para uma "autoridade superior", que assume temporariamente sua voz dentro da forma métrica e admite uma fala mais resoluta. Esse elemento dentro do soneto se constituiu como uma marca da manifestação da sabedoria da corte, segundo Spiller (1992). Todavia, Collin (2008), ao analisar o dístico na Inglaterra, principalmente em Shakespeare, observa que a função desses dois versos tende mais a ser o recurso para a conclusão do poema, sintetizando o tema abordado nos dois versos finais. 
Em paralelo, há uma segunda figura de igual importância para o desenvolvimento do soneto inglês: Henry Howard (1517-1547), o conde de Surrey, que se tornou responsável por intervir diretamente na composição do soneto, imprimindo características mais anglófonas, como o "novo" ritmo e esquema rímico, que foram incorporados por seus sucessores, chegando a Shakespeare. Hyland (2002) frisa que, em termos de estrofação, o soneto passa a ter três quadras e um dístico de rimas independentes para cada quadra e, no dístico final, rimas emparelhadas ( $a b a b c d c d$ efef $g g$ ). A partir dessa estrutura argumentativa, o discurso dentro do soneto se desenrola com mais fluidez e flexibilidade. Seguindo essa ótica, Hyland (2002) explana que uma maneira inequívoca de se criar um soneto na língua inglesa, segundo as modificações de Wyatt e sobretudo de Surrey, seria apresentar uma ideia ou declaração na primeira quadra, podendo ser uma metáfora; e então elucidar melhor, desenvolvendo a ideia ao longo da segunda e terceira quadra; e, por fim, fornecer algum tipo de comentário conclusivo no dístico. Hyland (2002) apresenta essa estrutura e diz considerá-la o caminho mais simples de se produzir um soneto na Inglaterra do século XVI e XVII, não desconsiderando, contudo, que haja outras formas de produzi-lo. Walker (2018) defende em sua dissertação de mestrado que os sonetos compostos por Surrey são formados por duas estrofes, sendo a primeira constituída por três instâncias tetrásticas, ou seja, uma estrofe de 12 versos complementada por uma segunda estrofe em forma de dístico, que se destaca do restante do poema e o arremata. Nesse caso, o poeta possivelmente irá tratar a primeira estrofe como uma única unidade, de 12 versos, seguida de uma segunda independente, com 2 versos.

No que concerne às razões subjacentes às modificações realizadas por Surrey, Hyland (2002) comenta que não se tem evidência concreta, mas que possivelmente o poeta almejava simplificar o número de rimas. A forma abba abba, por exemplo, precisaria de três palavras no final dos versos de número quatro, cinco e oito para rimar com o primeiro verso, enquanto que a forma $a b a b$, precisaria apenas de uma palavra no terceiro verso para rimar com o 
primeiro. Collin (2008) afirma que o esquema de rimas do italiano, embora com poucas variações rímicas - apenas cinco (de A a E) - assegura uma maior musicalidade às línguas neolatinas (italiano, francês, português e espanhol); no entanto, no caso do inglês, frisa o seguinte: "observamos haver maior dificuldade em se encontrar rimas para muitos versos e por isso, tentando evitar uma sonoridade monótona, os sonetista ingleses tiveram que buscar novas alternativas para o esquema de rimas" (COLLIN, 2008, p. 210). Logo, a estudiosa conclui que tenha sido assim o nascimento do soneto inglês, com a possibilidade de se variar entre as rimas $A$ a $G$, totalizando 7 combinações, onde cada rima é ouvida uma única vez.

Em termos de metrificação e ritmo, o soneto italiano passa a se distinguir do soneto inglês desde a sua introdução na Inglaterra por meio das traduções de Wyatt e seu posterior estabelecimento com as reformulações de Surrey. Enquanto na forma petrarquiana os versos têm 11 sílabas cada (hendecassílabos), nas traduções e produções de ambos os poetas ingleses o soneto assume a metrificação de 10 sílabas para cada verso, cujo ritmo passa a ser o pentâmetro iâmbico, isto é, versos de cinco pés ${ }^{20}$ cada, que se iniciam por uma sílaba métrica átona, seguida de uma tônica até o final do verso. Sendo assim, cada soneto é composto por 14 versos em pentâmetro iâmbico. Walker (2018) alega que a razão pela qual o soneto inglês admitiu o decassílabo em detrimento dos alexandrinos ou do hexâmetro iâmbico (versos de seis pés acentuados em todas as sílabas pares, ritmo utilizado geralmente nos versos de 12 sílabas), decorre do repertório lexical monossilábico vasto da língua inglesa. Hyland (2002) aponta que os tradutores adotaram o pentâmetro iâmbico como uma forma mais aproximada do hendecassílabo italiano. Todavia, essa escolha não se deu de maneira arbitrária ou por causas "naturais", como salienta o autor. Segundo Antony Easthope (1983 apud HYLAND, 2002) a preferência pelo pentâmetro iâmbico segue um viés ideológico dominante na Inglaterra do século XVI, que se refletia na estrutura

\footnotetext{
${ }^{20} \mathrm{Na}$ poesia de língua inglesa, a unidade rítmica mais comum é o pé, que permite a contagem por acentos, os quais podem ser longos e/ou breves, em combinações variadas, sendo uma delas o iâmbico, formado por uma sílaba átona e uma sílaba tônica.
} 
social aristocrata. Tais inovações resultam, assim, em um modelo clássico adequado ao gosto da cultura da corte, que deixa de lado as demais formas do verso inglês consideradas obsoletas. Portanto, a escolha por um estilo em detrimento de outros pode ser vista como uma necessidade de atender a um objetivo histórico específico.

Segundo essa ótica, nota-se que ambos os poetas integravam a cultura da corte, uma vez que Thomas Wyatt era diplomata e atuante nos serviços da realeza, e o seu contemporâneo mais jovem, Henry Howard, era conde de Surrey, incumbindo-se também das obrigações da nobreza. Harold Bloom (2008) sugere que há inclusive evidências de que seus sonetos circulavam pelas mãos da elite, sendo acessíveis principalmente para a corte; contudo, Spiller (1992) defende que nenhum dos dois logrou publicar seus poemas, pois Surrey foi executado com a idade de 30 anos sob alegação de traição, e Wyatt veio a óbito prematuramente, após uma febre repentina.

O grande público passou a ter acesso às produções dos tradutores por meio da publicação de uma antologia poética em 1557, organizada por um editor inglês muito influente conhecido como Richard Tottel (1530-1594). A obra publicada por ele se intitulava Songs and Sonnets written by the Right Honorable Lord Henry Howard late Earl of Surrey and other (Canções e Sonetos escritos pelo muito honorável Lorde Henry Howard falecido Conde de Surrey e outros) e ficou conhecida mais tarde por Tottel's Miscellany (Miscelânea de Tottel), composta por 271 poemas de Thomas Wyatt, Surrey, Nicholas Grimald e inúmeros outros tradutores. Hylland (2002) aponta que havia uma diversidade de formas poéticas trazidas para Europa e adaptadas para o vernáculo, registrando inclusive a primeira ocorrência do formato de versos brancos na história da Inglaterra.

Outro dado importante é que tanto o título da obra quanto o modo como ela se ordenava podem ter sido um dos fatores determinantes para 0 estabelecimento da composição do soneto para os sonetistas seguintes. Pode-se observar que o título da antologia coloca em evidência o nome de Surrey. Além disso, Spiller (1992, p. 91) aponta que a miscelânea foi 
organizada sequencialmente por 41 poemas atribuídos a Surrey, 97 poemas a Wyatt, 40 a Nicholas Grimald (1519 - 1562) e 94 atribuídos a "autores incertos". Dentre esses trabalhos, somente 13 eram sonetos de Surrey - com mais dois acrescentados à segunda edição, e 27 de Wyatt, embora três deles tenham sido transformados em um estilo poético-musical chamado rondeau (Rondó). Assim, Spiller (1992) sustenta que posicionar os sonetos de Surrey em primeiro lugar pode ter prestigiado o esquema 4-4-4-2, em detrimento dos demais formatos produzidos pelos outros tradutores. Tal organização contribuiu, portanto, para a divisão da oitava em três quadras e um dístico, que se encontra em 12 sonetos do total de 15 dispostos na antologia de Tottel, cujo esquema de rimas segue o sistema abab cdcd efef $g g$, diferentemente do modelo abba abba de Wyatt e dos sonetistas franceses. Todavia, apoiar-se nessa premissa não significa necessariamente que a publicação da miscelânea tornou o soneto popular, mas ao menos favoreceu o modelo que fora introduzido por Wyatt e desenvolvido por Surrey.

Spiller (1992) sinaliza que a popularidade dos sonetos não está atrelada à publicação de Tottel, pois, como verifica o estudo de Silva Ramos (2008), os escritos de Surrey e Wyatt já circulavam de maneira isolada durante o reinado de Henrique VIII. Pode-se verificar, no entanto, que a coletânea abriu espaço e forneceu estímulo para outros editores a publicarem obras com os mesmos propósitos. Hyland (2002) aponta que se iniciou um processo de disseminação dos sonetos que passou a abranger um público maior, antes limitado à elite. Já Collin (2008) defende que a grande voga do soneto na Inglaterra se deu a partir da publicação da obra póstuma de Sir Philip Sidney (1554-1586), sob o título de Astrophel and Stella (Astrophel e Stella), em 1591, próximo ao fim do reinado da rainha Elisabete I. Foi nessa época que o soneto veio de fato a ser adotado na Inglaterra como expressão lírica dos poetas, embora na França a conjuntura fosse outra, com a produção de sonetos já tendo alcançado o seu auge.

Sir Sidney Lee (1910 apud RAMOS, 2008) salienta que não houve sequer um poeta entre os anos de 1590 a 1610 que não tenha tido a 
oportunidade de experimentar a estrutura popularizada por Sidney. Por exemplo, após o advento de sua obra, há registros das produções de Samuel Daniel (1562-1619), com a publicação de Delia em 1592; de Michael Drayton (1563-1631), com Ideas Mirror em 1594; Sir Edmund Spenser (1552-1599), com Amoretti em 1595; em 1596, Cynthia, de Richard Barnfield (1574-1620), e dentre tantos, William Shakespeare (1564-1616) em 1609, com The Sonnets. Bloom (2008) menciona que uma das razões pelas quais os sonetos se popularizaram por intermédio de Sidney foi o seu reconhecimento como herói nacional, pois, ao que tudo indica, ele veio a óbito em 1586 devido às feridas recebidas em campo de batalha na Holanda.

Astrophel and Stella, obra composta por 108 sonetos intervalados por 11 canções, tem como objeto de desejo a filha mais velha do primeiro conde de Essex, Penelope Devereux, conhecida como Lady Rich, a quem Sidney conhece por volta de 1581. Ela sintetiza todo o erotismo que é um traço marcante na obra do poeta e que o diferencia de seus conterrâneos. Além disso, Spiller (1992) sinaliza outros traços que são bem evidentes nos sonetos desse poeta, como o absurdo e o irônico, muitas vezes retratados em tom lamurioso. Segundo o estudioso, Sidney foi o primeiro poeta a descontruir a figura do eu lírico enaltecedor. Hyland (2002) acredita que, embora o modelo para seus sonetos na obra de 1591 fosse Lady Rich, referências a Elisabete I não são difíceis de serem identificadas, uma vez que Sidney voluntariamente se exila em Wilton, pois se opõe à proposta de matrimônio que a rainha recebera por parte do duque de Alençon. É por isso que, em determinados momentos, notam-se as frustações apresentadas pelo poeta: ora por não ter se casado com Penelope, ora por discordar de toda a questão de um possível casamento entre o duque francês e a rainha da Inglaterra. Por esse viés, é possível supor que a sequência de sonetos de Sidney estivesse pautada nos descontentamentos ocorridos na vida do poeta (HYLAND, 2002).

Seguindo a ótica de Collin (2008) de que "todos os poetas estabeleceram uma gradual transformação do soneto como expressão lírica da Inglaterra [...]" (p. 210), observa-se que, embora Sidney se sujeitasse a 
muitas das convenções do soneto petrarquiano, ele também contribuiu com algumas inovações. Sendo um explorador dos aspectos formais (HYLAND, 2002), Sidney experimentou versos com tamanhos diferentes do padrão de dez sílabas, além de promover uma grande variação no esquema rímico do soneto, embora observasse o dístico final. Sobretudo nas obras anteriores a Astrophel and Stella, evidencia-se um esquema em aaaa aaaa aaaa aa, bem como abab baba acac cc. Já na sua publicação de 1591, opta por utilizar a forma do soneto inglês $a b a b c d c d$ efef gg, e além disso, privilegia um tom mais coloquial e dramático. Spiller (1992) também aponta o uso dos apóstrofos como outro traço marcante nos sonetos de Sidney, uma vez que o poeta inglês se utiliza desse recurso para intensificar e dar um teor dramático ao poema, indicando a presença de um interlocutor imaginário. Nesse sentido, o leitor assumiria uma posição de observador de um diálogo que se desenrola entre o eu lírico e seu interlocutor.

As diferenças entre Sidney e Petrarca são notáveis, pois se observa que Petrarca questiona o valor de seu amor por Laura, mas nunca sua real existência (HYLAND, 2002). Sidney, por sua vez, avalia a realidade desse sentimento por Stella, mas nunca o seu valor, e confere ao poema traços de coloquialidade, bem como de uma sensualidade ovidiana. Ressalte-se, no entanto, que para Spiller (1992) essa característica sensual dos poemas de Ovídio (43 a.C. - 18 d.C) não foi introduzida por Sidney, mas pelos poetas franceses Pierre de Ronsard (1524-1585) e Jean-Antoine de Baïf (1532-1589), que já haviam trazido esse recurso para a Europa. Cabe aqui mencionar dois fatos que assemelham as obras do poeta inglês as do italiano: a relação entre o eu lírico encontrado em Astrophel and Stella com um objeto inacessível parece corresponder a uma das convenções encontradas em Petrarca, que a torna uma prática comum entre os sonetistas em geral (HYLAND, 2002); e a publicação póstuma de Sir Philip Sidney obteve fama de maneira análoga à do poeta italiano, uma vez que ambos assumiram um lugar de referência somente após suas mortes. Nesse sentido, Spiller (1992) chama a obra Astrophel and Stella de "Petrarch-fashion" (ao estilo de Petrarca). Contudo, 
Silva Ramos (2008) defende que Sidney havia assumido uma concepção antipetrarquiana - reverberando até entre os amigos desse poeta inglês - que buscava se afastar de toda uma moda ideológica e estilística difundida na Europa.

Outro poeta de igual importância dentro do sistema literário inglês, que alcançou maior notoriedade a partir dos anos finais do século XVI e início do XVII, foi Sir Edmund Spenser (1552-1599), com sua obra Amoretti (1595). Spiller (1992) salienta que o poeta teve muito destaque dentro do complexo gênero épico inglês, tendo escrito seis livros desse gênero antes de sua sequência de sonetos. Além disso, o estudioso afirma que Spenser tinha grande controle de narrativas longas, bem como da poesia épica, como se observa em uma obra anterior sob o título de The Faerie Queene (A Rainha das Fadas), publicada por volta de 1590.

Acerca de sua sequência de sonetos, Hyland (2002) acredita que Spenser traz para os poemas um desejo adúltero e carnal - implícito no estilo petrarquiano - em um casamento cristão. Ele inclusive estrutura seus sonetos sob a forma do ano eclesiástico, e a sequência termina com um sentimento de frustração. A característica que o estudioso destaca é que há uma integração entre traços eróticos e espirituais, entre a convenção poética e a autobiografia, o que mostra uma grande aproximação do estilo do poeta italiano, uma vez que este enaltece Laura tanto em vida quanto em morte, trazendo aspectos terrenos e espirituais e se embasando nos eventos de sua vida. Já o estudioso Gary Waller (1994), que dedica uma obra inteira à vida literária de Spenser, argumenta que em sua única realização lírica, Amoretti, Spenser demonstra claramente traços antipetrarquizantes, pois a obra foi escrita sobretudo com o intuito de distanciar o poeta inglês da secularização de toda uma tradição petrarquiana, rejeitando o modelo de amor apresentado pela moda da corte. O amor abordado por Spenser não é tomado como um elemento perturbador da ordem, mas embasa-se em propósitos morais. Seguindo essa ideia, Sinfield (1983 apud WALLER, 1994, p. 169) afirma que a obra Amoretti é uma "adaptação humanista puritana" que efetua uma crítica protestante à 
repercussão dos modos de pensamentos e expressão petrarquianos. Vale ressaltar, uma vez mais, que a característica antipetrarquiana já vinha se desenvolvendo entre os sonetistas ingleses, como é o caso de Sidney, que também adotou essa perspectiva. No entanto, Spenser não esvazia sua arte da sensualidade constitutiva do soneto petrarquiano. Para Waller (1994, p. 131) "arte e sensualidade podem, mesmo no esquema moral de Spenser, ser aceitáveis para a humanidade, desde que possam ser desfrutadas não por si mesmas, mas dentro de toda uma ordem cósmica"21.

No que concerne aos aspectos formais, Spenser contribuiu com uma forma de versificação cadencial, isto é, seguindo um esquema de rimas abab $b c b c$ cdcd ee, no qual cada pensamento é introduzido em momentos bem marcados (SPILLER, 1992). Essa estrutura padronizada possivelmente adveio de suas experiências com o estilo da balada escocesa, como aponta o estudioso. Spiller (1992) ainda sinaliza que quase não há uma linha ou palavra de transição de uma quadra para outra. Logo, o leitor não nota uma mudança repentina, por causa da cadência nas rimas, que lhes confere uma continuidade discreta. $O$ estudioso avalia também que Spenser produziu um soneto mais bem desenvolvido em termos de coerência do que todos os seus contemporâneos, ressaltando que sua forma de explorar as quadras como cadências não foi adotada por nenhum outro poeta.

$\mathrm{O}$ que se pode verificar, a partir dos poetas aqui aludidos, e atestar, levando em conta suas publicações, é que o soneto como forma de expressão lírica dos escritores ingleses se torna um modelo efervescente a partir de Sidney em 1591. Spiller (1992) comenta que os editores ficaram incentivados com as numerosas produções e começaram, então, a se empenhar vigorosamente na editoração e publicação dessas obras. O estudioso ressalta que a grande voga durou quatro anos, de 1593 a 1597, e pontua que mesmo aqueles outros sonetos que vieram a público posteriormente a esse período durante o reinado de Jaime I na Inglaterra, por exemplo - já circulavam

21 "Art and sensuality may, even in Spenser's moral scheme, be acceptable to humankind, so long as they can be enjoyed not for their own selves, but within a whole cosmic order". 
reservadamente sob a forma de manuscritos, como é o caso de algum dos sonetos do Bardo. No entanto, vale expor aqui a indagação de Spiller (1992) quanto à popularidade dessa forma poética. Ele questiona a razão pela qual o soneto se manteve com tanta visibilidade no período, enquanto outras formas existiam e eram igualmente populares, como o romance de cavalaria.

Alguns estudiosos poderiam sustentar a ideia de que os poetas viram essa "nova" forma lírica como um meio de ganhar alguma renda ou mesmo lograr obter um novo trabalho ao explorar esse modelo poético. Hyland (2002) responde que sobretudo o soneto detinha um peso ideológico dentro da comunidade aristocrática, incluindo aqueles que estavam a serviço da rainha, uma vez que grande parte dos sonetistas não eram poetas profissionais, mas cortesãos e membros da elite social. Além disso, o estudioso atruibui o sucesso e a popularidade do soneto ao fato de o trono ser ocupado por uma figura feminina, uma governante de imenso poder que se tornou objeto de um desejo inatingível entre os cortesãos e poetas da época. Consequentemente, Hyland (2002) associa o término da moda dos sonetos ao falecimento da rainha e, ademais, sustenta o argumento de que o soneto era uma forma pela qual a elite mantinha sua exclusividade: "o poder precisa de segredos, e até os sonetos podem funcionar como tais, pois carregam os valores de um grupo exclusivo"22 (p. 131). Quando o grande público teve acesso a essa forma "restrita", sua propagação se tornou um sucesso. Christopher Warley (2005) segue pelo mesmo viés, afirmando que o prestígio que o soneto alcançou deveu-se a dois fatores: o poder da corte inglesa que estava em vigor e a predominância dos princípios humanistas que vinham se difundindo como movimento intelectual durante a época por todo o continente. Ele ainda considera a linguagem petrarquiana como um fator facilitador, de viés político e ideológico, na construção da corte elisabetana, o que, consequentemente, gerou a voga dos sonetos. Ao mesmo tempo que destaca esse evento, questiona outro, acerca da figura da rainha como principal viabilizadora da

22 "Power needs secrets, and even sonnets can be secrets in this sense: they carry the values of the select group". 
moda dos sonetos, indagando: por que tal moda só surgiu 25 anos após sua ascensão ao trono? E sugere, ao final desse diálogo, que os sonetistas ingleses de alguma maneira se inseriram tardiamente no sistema literário renascentista, mas a pergunta ainda fica em aberto. Outro estudioso que liga a moda dos sonetos a um fato histórico é Gary Waller (1994), que sustenta que a produção dos sonetos estava diretamente vinculada à formação nacional e à expansão de uma economia que saíra de uma estrutura medieval e se desenvolvia em um mercado nascente de colônias e domínios.

Já Spiller (1992) também expressa sua perspectiva acerca de tal voga. Ele acredita que o modelo do soneto desenvolvido nos anos finais do século XVI possibilitava três formas discursivas que o poeta era capaz de assumir: a reflexiva ou estoica; o espírito anacreôntico; e a postura apaixonada e cobiçosa, esclarecendo que a primeira se refere a um discurso do observador, cuja postura mais branda e mais intermediária, o torna uma generalised authority (p. 127), isto é, uma autoridade amplamente aceita ou estabelecida. Spiller (1992) afirma que essa ascese medieval era também um produto da cultura cortesã da época. Já o espírito anacreôntico era geralmente apresentado pelo enaltecimento do amor na figura do Cupido provido de asas, tocha, arco e flecha, uma vez que referências a personagens clássicos da mitologia greco-romana era um traço comum entre os escritores da Renascença. A última e mais marcante das três características abordadas nos sonetos era o discurso apaixonado, bem comum para o estilo que Spiller (1992) considera como love poetry (poesia de amor). No entanto, esse autor ressalta que a paixão era pensada pelos ingleses em um sentido mais amplo do que se compreende hoje, isto é, estar apaixonado significaria ter fortes sentimentos em relação a um objeto de desejo, ou de desprezo. Em contrapartida, o vocábulo "desejo", em sua forma singular, denotava um sentido mais estrito, ou seja, um apetite meramente carnal, que nesse caso, estaria em oposição ao amor. Nesse sentido, Spiller (1992) assevera que aqueles poetas que estivessem de fato apaixonados pela figura de uma mulher atingível certamente ofereceriam sinceros sonetos de amor a ela. Ademais, 
aqueles que tivessem um afeto não sexual por uma figura inatingível como, por exemplo, seus patronos ou reis e rainhas, também Ihes dedicariam uma forma de soneto de amor. Isso inclusive torna possível a celebração do amor homossexual sem nenhuma ofensa aos padrões morais elisabetanos, como afirma o estudioso. Outro fato não tanto evidente, segundo Hyland (2002), é a forma de soneto que escapava à crítica literária da época, o elogio geralmente posicionado no início ou no final de textos das áreas de Teologia, Direito ou qualquer outra, cujo conteúdo não fosse literário. Assim, essas produções encontram novos espaços dentro do contexto econômico inglês, se apresentando como mais um elemento em benefício do comércio em expansão.

Toda a conjuntura do século XVI já se encaminhava para 0 florescimento dos sonetos, que viria a se concretizar com a publicação da obra de Sir Philip Sidney. Essa forma poética havia se tornado, como já salientado, a expressão lírica da cultura da corte, dando exclusividade àqueles que tinham acesso a ela (HYLAND, 2002); contudo, foi em 1591 que o soneto veio a integrar o grande público inglês. Nesse sentido, o soneto é introduzido na Inglaterra a partir da técnica da imitação e se desenvolve dentro do sistema literário renascentista, moldando-se conforme as contribuições e soluções de seus escritores. Estabelecia-se, assim, uma gradual transformação (COLLIN, 2008), que culminou no chamado "soneto inglês". Esse, por sua vez, não só replica a linguagem do amor petrarquiano como também se expande por outras esferas discursivas: a espiritual, a moral, a lamentação, entre outras.

Os sonetos shakespearianos ganham o mundo editorial pela primeira vez, segundo Harold Bloom (2008), em 1599, em uma antologia poética elaborada por William Jaggard (c. 1568-1623), que reunia vários poetas elisabetanos, intitulada The Passionate Pilgrim (O peregrino apaixonado). Os primeiros sonetos shakespearianos que alcançaram o grande público foram os de número 134 e 138. Todavia, são necessárias duas ressalvas: Smith (2008) aponta que em 1596 Shakespeare já era considerado um dramaturgo de renome, tendo produzido várias obras teatrais. Portanto, entende-se que 
sua sequência de sonetos não foi um fator decisivo para sua fama. Bloom (2008) assegura que alguns dos sonetos produzidos pelo Bardo já circulavam pelas mãos de amigos antes mesmo da publicação dos dois sonetos em 1599 por Jaggard, uma vez que se verifica a primeira menção aos "sonetos açucarados" 23 em 1598, por Francis Meres (1565-1647), em sua obra Palladis Tamia.

Seguindo essa ótica, estudiosos da obra lírica de Shakespeare especulam que o Bardo tenha se concentrado na produção dos sonetos justamente entre os anos de 1592 a 1598, que foi a época da grande voga dessa forma métrica, como comenta Silva Ramos (2008). Também Collin (2008) observa que há uma forte probabilidade de que os primeiros sonetos tenham sido escritos a partir de 1592-93, sustentando a ideia de que em 1598 já circulavam em manuscritos entre seus amigos mais íntimos, e que por volta de 1603-1604 os sonetos já se encontravam compilados em uma sequência. Hyland (2002) salienta que Shakespeare começou a escrever seus sonetos muitos anos antes da publicação de 1609, mas que não se sabe exatamente quando tais produções ocorreram, cabendo especulações das mais convincentes ao longo dos anos. Ele aponta que estudiosos têm sustentado a ideia de que o Bardo possa ter escrito seus sonetos durante os anos de 159293, quando produziu também suas duas outras obras líricas, Venus and Adonis (Vênus e Adônis) e The Rape of Lucrece (A Violação de Lucrécia), publicadas respectivamente em 1593 e 1594. Spiller (1992), por sua vez, se exime de afirmar uma data específica para a produção dos sonetos, mas ressalta que muitos estudiosos tendem a concordar que foi entre 1592 e 1599 que Shakespeare os compôs. É possível concluir, portanto, que não há consenso quanto a essas datas, e que as análises que se evidenciam são meramente especulações que, embora pareçam convincentes, sempre serão passíveis de refutação.

Os sonetos de Shakespeare publicados em 1609 pelo editor Thomas Thorpe levantam grandes debates. Bloom (2008) pontua que não há

23 "Sugared sonnets" (MERES, 1598 apud BLOOM, 2008). 
evidências de que o Bardo tenha autorizado a publicação pelo editor ou mesmo a ordenação da sequência na qual veio a ser publicada. O estudioso frisa ainda que nessa publicação se encontram diversos erros ortográficos, e que existem atualmente apenas 13 volumes extremamente raros; logo, alguns pesquisadores acreditam que Shakespeare pode ter procurado destruir as cópias, pois poucos exemplares sobreviveram (BLOOM, 2008). Em contrapartida, Katherine Duncan-Jones (1997), editora da edição Arden de The Sonnets, crê que Shakespeare tenha autorizado a publicação de Thomas Thorpe, uma vez que a obra lírica é seguida do poema narrativo $A$ lover's complaint (Queixas de uma enamorada). Essa última hipótese é digna de muitas discussões entre estudiosos como John Kerrigan e Katherine Rowe, a nomear alguns. Mas ainda assim, Duncan-Jones (1997) continua a argumentar que a organização da obra The Sonnets não tem caráter mercadológico oportunista por parte de Thorpe, mas segue o padrão das obras poéticas da época. Já Silva Ramos (2008) sustenta que Shakespeare provavelmente não autorizou a publicação de 1609, nem mesmo supervisionou a compilação e ordenação da obra. Entretanto, comenta que há especulações acerca de um possível consentimento do poeta inglês. Dentre essas, ressalta a de Dover Wilson, que propõe a ideia de que, como o Bardo não estava interessado em divulgar seus sonetos "íntimos", a própria Dark Lady - figura feminina aludida nos sonetos que os estudiosos tentam identificar, como será analisado com mais detalhes posteriormente - pode ter oferecido a Thorpe tais escritos, talvez por alguma intenção financeira. Por sua vez, Collin (2008) comenta a especulação de que o Bardo tenha sido forçado a publicar seus sonetos devido à conjuntura da época, pois os teatros estavam com poucas atividades, devido à peste negra que já havia feito várias vítimas em Londres de 1603 e que continuava a fazê-las em 1608. Como consequência, para complementar seu orçamento, vendeu os manuscritos. A estudiosa afirma que, embora essa seja uma mera especulação, é possível precisar que em 1609 os sonetos estavam prontos para publicação, sendo a coleção intitulada Shake-speare Sonnets (Os sonetos de Shakespeare). Tal 
publicação não rendeu lucros nem fama, pois poucas cópias foram vendidas e não houve uma reedição. Hyland (2002) salienta que, como Thorpe era um editor de carreira e com reputação na sociedade inglesa, julga ser difícil ter publicado uma obra sem qualquer consentimento do poeta inglês, sob o risco de comprometer seu ofício. Portanto, o estudioso se volta para a teoria de que Shakespeare tenha de fato autorizado a publicação de 1609.

O último registro que se tem de outra edição dos sonetos de Shakespeare se deu trinta anos após a de Thomas Thorpe e, se a publicação de 1609 não foi oportunista, a que veio posteriormente certamente o foi, e, ainda, perdurou por dois séculos como a única edição dos sonetos do Bardo (BLOOM, 2008). Em 1640, John Benson (16-? -1667) reuniu e publicou em uma coletânea os sonetos de Shakespeare, cuja proposta era apresentar um volume recém-impresso. Entretanto, estudiosos julgam essa publicação uma obra pirata, pois traz alterações dentro dos próprios sonetos - como é o caso da mudança pronominal dos sonetos dedicados ao Belo Jovem, que em sua nova versão se dirigem à tradicional mulher amada. Benson também atribuiu títulos aos sonetos e juntou algum deles em poemas maiores, descaracterizando assim a forma do soneto e a sua composição original produzida pelo Bardo, além de atribuir erroneamente a Shakespeare alguns dos poemas encontrados em O peregrino apaixonado. Bloom (2008) e Collin (2008) afirmam que durante dois séculos essa foi a única edição que ficou disponível para leitores e admiradores das obras de Shakespeare. 


\section{4 \\ OS SONETOS DE SHAKESPEARE}

Not marble, nor the gilded monuments
Of princes, shall outlive this powerful rhyme;
But you shall shine more bright in these contents
Than unswept stone, besmeared with sluttish time.
WILLIAM SHAKESPEARE (sonnet 55)

Os sonetos produzidos pelo Bardo são singulares e constituem uma forma aperfeiçoada do soneto inglês inicial (COLLIN, 2008). Portanto, dada a peculiaridade dessa estrutura então desenvolvida por Shakespeare, dedica-se aqui um capítulo exclusivamente para tratar de seus sonetos, bem como da publicação de 1609, já que estudiosos reconhecem ser o primeiro volume compilado que veio a público. A análise que se propõe neste capítulo não é de forma alguma plena, e conta com os estudiosos já elencados, como Spiller (1992); Katherine Duncan-Jones (1997); Peter Hyland (2002); Paul Edmondson e Stanley Wells (2004); Harold Bloom (2008); Silva Ramos (2008); Collin (2008); e Walker (2018), entre outros, uma vez que se compreende que em todas as obras líricas de Shakespeare, sobretudo os sonetos, há uma amplitude de elementos que necessitam de atenção. Todavia, diante da proposta de contextualizar e contrapor os sonetos de Shakespeare com a de poetas que o precederam, inclusive Petrarca, a primeira parte deste capítulo será voltada para elementos, temáticas e personagens que se destacam nos sonetos shakespearianos, para na segunda parte abordar o modo como os tradutores brasileiros buscaram transpor essa produção lírica.

Como já salientado, os sonetos do Bardo vieram a lume pela primeira vez no ano de 1609 pelas mãos do editor Thomas Thorpe, em um volume que admite diversas especulações. Seus sonetos e a quem eles se endereçam recebem igualmente novas proposições e refutações por parte dos estudiosos. No que concerne à obra como um todo, ela consiste em 154 sonetos, cuja temática está pautada na reflexão sobre a natureza da amizade, do amor, da procriação, da morte, do tempo e da própria poesia. A maior parte dos primeiros 126 sonetos tematizam a amizade e a admiração entre o eu lírico e 
um nobre jovem, que é pressionado para gerar filhos, de modo a não morrer infeliz, sem a alegria de contemplar sua beleza na progenitura. Já os sonetos 127-52 em sua maioria tratam da senhora de cabelos negros, a Dark Lady. Além disso, os dois últimos sonetos, 153-4, parecem não estar relacionados a qualquer tema abordado anteriormente, constituindo-se, como observa Collin (2008), "adaptações de versos clássicos sobre o Cupido" (p. 224). Para a estudiosa, aludir a tais figuras mitológicas causa a impressão de que o Bardo se afasta de toda a atmosfera até então criada. Spiller (1992) aponta que essa característica anacreôntica conferiu aos sonetos finais um caráter de independência dos demais. Para o estudioso, Shakespeare pode ter buscado expressar no eu lírico seus próprios desejos com tanta intensidade, que não observou a continuidade da sequência dos sonetos. Já Hyland (2002) destaca que, embora alguns estudiosos concebam os dois últimos sonetos como membros que não fazem parte do corpo da obra, a expressividade cínica que os compõe fornece um desfecho bem apropriado não só para os sonetos dedicados à Dark Lady, como para toda a sequência, pois se move em direção à desilusão e à amargura. Nesse sentido, os sonetos finais, segundo o estudioso, têm na figura do Cupido a fonte do "fogo do amor", e esse "fogo" que se identifica no olhar da amada tem dois significados: a paixão e a doença. A única cura possível para esse fogo é a água, mas ela não é capaz de apagálo; pelo contrário, o fogo subsiste e esquenta a água, e a sequência conclui com um tom de derrota do eu lírico diante do fogo do amor.

No que tange a seus primeiros leitores, esses nem sempre estão identificados tão claramente, mas sabe-se, ao menos, que os escritos do Bardo, antes da publicação de 1609, já circulavam pelas mãos de seus amigos íntimos (ORGEL, 2006). O tradutor Jorge Wanderley (1991) salienta que os sonetos de Shakespeare assumem uma característica especial de poemas de circunstância. Ele os chama de duty-sonnets, isto é, sonetos escritos com a intenção de agradar ao seu "grão-senhor" (p. 9), portanto, eles representam de alguma maneira afeto, amizade, dedicação, devoção, aversão, e estão imbricados em um contexto circunstancial, de modo que em diversas ocasiões 
o leitor é capaz de identificar a quem eles se endereçam - ao Fair Youth, ou Belo Jovem; à dama referida como Dark Lady e ao Poeta Rival. Entretanto, o tradutor ressalta que Shakespeare transcende tal condição circunstancial, pois se desassocia do contexto "para luzir num céu exclusivo [...] ainda que tenha partido da realidade ou da fantasia mais comezinhas" (p.10). Vale ainda dizer que, embora aparentemente os sonetos tenham sido dedicados ao jovem, à mulher e ao poeta rival, isso não significa afirmar que eles foram exclusivamente endereçados a um único jovem, a uma única mulher ou mesmo a um único rival (EDMONDSON; WELLS, 2004).

É compreensível, no entanto, que a publicação de 1609 receba diversas especulações, desde a razão que estimulou o editor Thomas Thorpe a compilar e publicar os manuscritos de Shakespeare, até os dois últimos sonetos de sua obra que não seguem a ordem ${ }^{24}$ nem expressam uma coerência esperada pelos estudiosos. $O$ intrigante caso da dedicatória $M r . W$. $H$. que se encontra na publicação de 1609 torna-se similarmente alvo de teorias sobre a sua real identidade. Vale, nesse caso, ressaltar aqui, mesmo que brevemente, tal debate.

Silva Ramos (2008) examina as formulações acerca dos candidatos a objetos da dedicatória Mr. W. H., afirmando que essa ocorrência está ligada diretamente ao sentido de begetter, que pode assumir dois significados: "alcançar/obter"25, como a tradução do verbo to beget; ou "inspirador" embora begetter seja um substantivo. Seguindo o primeiro sentido sustentado pelo tradutor, a dedicatória que se lê To the onlie begetter of these insuing sonnets Mr. W.H. poderia ser traduzida da seguinte maneira: "Dedicado àquele que obteve (alcançou) estes seguintes sonetos, Mr. W.H.". Assim, a dedicatória faria uma referência direta à pessoa que obteve os manuscritos para Thomas Thorpe. Para Silva Ramos (2008), existem algumas teorias que seguem esse viés, considerando que Mr. W.H. poderia ser um desses três

24 Os autores Edmondson e Wells (2004) criticam a ideia de The Sonnets ser uma sequência narrativa. Para eles, a obra se apresenta mais como uma coletânea de sonetos.

${ }_{25}$ Segundo comenta o tradutor (p. 18), o sentido atribuído ao verbo to beget como "obter/alcançar" de onde se deriva begetter é atestada por meio do fragmento em Hamlet ato III, 2.8: You must acquire and beget a temperance. 
nomes: William Hart, cunhado de Shakespeare, como especula Richard Farmer (1767 apud RAMOS, 2008); William Harvey, padrasto do terceiro conde de Southampton, segundo afirmam os estudiosos Frederick Fleay (1831-1909) e Charlotte Stopes (1840-1929); e William Hall, impressor que trabalhou com Thorpe em outras publicações, como acredita Sir Sidney Lee, citado por Silva Ramos (2008). Por outro lado, seguindo a ideia de que begetter poderia significar "inspirador", Silva Ramos (2008) apresenta três hipóteses como as mais apreciadas entre os estudiosos: a primeira referente ao terceiro conde de Southampton, Henry Wriothesley (1573-1624) - por inversão das iniciais - como a figura inspiradora para a composição dos sonetos do Bardo, sobretudo os sonetos iniciais (1-17), que incentivam o jovem a casar-se e a procriar, sob pena de morrer infeliz. Como se registra que Southampton tenha rejeitado o casamento com Lady Elizabeth de Vere (1575-1627), e que também o próprio conde tenha sido o destinatário das dedicatórias dos outros dois poemas do Bardo (Vênus e Adônis e Violação de Lucrécia), a suposição de que ele tenha sido o inspirador dos sonetos se acentua. Outra hipótese considera o terceiro Conde de Pembroke, William Herbert (1580-1630), também como um forte candidato para a figura inspiradora dos sonetos, uma vez que o Primeiro Fólio (1623) das peças do Bardo foi dedicado a ele e a seu irmão, conde de Montgomery. Além disso, havia a proposta de um casamento entre William Herbert e Elizabeth Carey (1576-1635), neta do patrono da companhia teatral de Shakespeare. Já na terceira especulação, o que se crê é que o inspirador da obra dos sonetos possa ter sido o jovem ator homossexual William Hughes, que representava papeis femininos nos palcos. Silva Ramos (2008) ressalta que essa última teoria tem sido endossada sobretudo por poetas, ficcionistas e teatrólogos, diferentemente das anteriores que foram apresentadas por estudiosos de Shakespeare.

É importante observar que o conceito do vocábulo begetter atribuído por Silva Ramos (2008) difere-se do sentido fornecido pelo dicionário Merriam- 
Webster ${ }^{26}$ em sua plataforma on-line, que assume a ideia de procriação, o que erotiza a coleção de poemas a partir de sua dedicatória. Tal hipótese, embora não trazida por Silva Ramos (2008), ganha espaço em alguns paratextos dos tradutores dos sonetos shakespearianos que serão discutidos posteriormente, bem como transparece em suas traduções. Em contrapartida, outros profissionais da tradução se eximem de verter sobre tal temática, mesmo que suas traduções dos sonetos estejam orientadas para a temática do amor.

Com respeito aos sonetos especificamente, pode-se identificar três personagens característicos a quem o eu lírico normalmente se refere: o Belo Jovem, a Dama Negra e o Poeta Rival ${ }^{27}$. Similarmente aos casos de vastas especulações aqui trazidas, os personagens aludidos nos sonetos são ainda hoje alvos de constantes hipóteses. Não se sabe ao certo se eles de fato existiram, nem se eram os únicos destinatários (EDMONDSON; WELLS (2004), o que poderia conferir à obra dos sonetos um caráter autobiográfico. Mas o que se pode depreender dos sonetos quanto à figura do Belo Jovem é que era um jovem rico, belo, bem integrado na sociedade, personagem da corte ideal (COLLIN, 2008), a quem o eu lírico confessa a sua afeição. A declaração desse sentimento que frequentemente se prefigura como amor, segundo Orgel (2006), era algo comum na cultura renascentista inglesa, principalmente no âmbito da patronagem. $O$ estudioso ainda salienta que a declaração amorosa ao homem tendia a ser mais idealizada, enquanto que aquela dedicada à mulher comumente se apresentava como um ato destrutivo até mesmo perigoso. Contudo, Edmondson e Wells (2004) ponderam que uma das características de distinção de Shakespeare é que, enquanto para muitos de seus conterrâneos o(a) amado(a) era idealizado, em The Sonnets encontrase um amado imperfeito.

\footnotetext{
26 No original: Be.get - Transitive verb - 1: To procreate as the father (Cf. https://www.merriamwebster.com/dictionary/beget)

27 Os autores Edmondson e Wells (2004, p. 54) asseveram que há quatro tipos de pessoas presentes nos sonetos: três homens e uma mulher. A primeira é a voz poética - que pode ser também imaginada como uma figura feminina; a segunda é o homem a quem parte dos sonetos é endereçado; a terceira pessoa é o poeta, que está amorosamente conectado tanto com o homem quanto com a dama que, por sua vez, é a quarta pessoa
} 
As duas hipóteses mais reverenciadas entre os estudiosos acerca da identidade do jovem é a do conde de Southampton, Henry Wriothesley, e a do conde de Pembroke, William Herbert, uma vez que há fatos em suas vidas relacionáveis às circunstâncias dos sonetos. Já em relação à Dama Negra, personagem normalmente aludida entre os sonetos 127 e seguintes, o que se pode compreender é que o poeta inglês ressalta sua beleza morena, em detrimento do padrão europeu, e desconstrói preconceitos estéticos (WANDERLEY, 1991), além de também haver uma relação mais carnal entre o eu lírico e a figura desse segundo ciclo de sonetos. Nessa ótica, a figura feminina muito exaltada nos sonetos como merecedora do amor do eu lírico durante toda a tradição petrarquiana é contraposta, e até mesmo subvertida, quando o poeta confere ao jovem o seu amor em sentido amplo, bem como uma imagem quase que idealizada, que se verifica no primeiro ciclo dos sonetos. Por outro lado, à mulher é atribuído o desejo em sentido estrito, isto é, o sexual, sendo também objeto de sátiras em determinados momentos, como é o caso do soneto 130. No que tange à identificação da Dama Negra, Hyland (2002) apresenta duas fortes candidatas: Mary Fitton (1578-1647) e Aemilia Basano (1569-1645). Fitton, dama de companhia da rainha Elisabete I, teve um relacionamento amoroso proibido com o conde de Pembroke, romance que o fez ser preso em 1601. Hyland (2002) sinaliza que embora a cortesã não apresentasse traços negros, inferir que ela tenha sido a Dark Lady acentua ainda mais a ideia de que Pembroke foi o Belo Jovem, já que há nos sonetos registros de um triângulo amoroso entre o eu lírico, a Dama Negra e o Belo Jovem. A segunda candidata, Aemilia Basano, criada por uma família aristocrata, aparentava ter um tom de pele moreno, dado a sua descendência inglesa-judaica-italiana (HYLAND, 2002). Foi amante de Lord Hunsdon (15261596), patrono da companhia teatral de Shakespeare, Lord Chamberlain's Men. Posteriormente, Basano se casou com seu próprio primo, Alphonso Lanyer (1572-1613), que era músico da corte. Hyland (2002) menciona que ela tinha certa ligação com o teatro, contudo, não há qualquer relação com o suposto Mr. W.H., a quem se dedica a coleção de sonetos. A terceira figura 
aludida nos sonetos, no entanto, com pouca ocorrência em comparação com as duas anteriores, é a o do Poeta Rival. Collin (2008) salienta que ele aparece em nove sonetos $(21,78,79,80,82,83,84,85$ e 86) e que pode ter sido encarado por Shakespeare com preocupação, já que durante sua época havia constantes disputas por patrocínio entre os escritores para que conseguissem publicar seus trabalhos. Seguindo essa concepção autobiográfica, George Chapman (1559 -1634) seria a figura mais provável, uma vez que ele ofereceu alguns de seus poemas ao conde de Southampton, patrono de Shakespeare. Há, todavia, outros contemporâneos que poderiam ter instigado rivalidade, como John Donne (1572-1631), Edmund Spenser (1552-1599) e Christopher Marlowe (1564-1593), entre outros. No entanto, o que se sabe dos sonetos é que o Poeta Rival é normalmente tratado com uma certa aversão e ironia, uma causa de insegurança para o eu lírico, e uma figura enganosa que rouba a beleza e o comportamento do Belo Jovem para então ofertar-se a si mesmo como um presente (BLOOM, 2008), como é o caso do soneto 79.

Nessa atmosfera de contradições e incertezas, a escrita shakespeariana, sobretudo nos sonetos, se destaca pela amplitude em que se desenvolve nessa forma poética. A abrangência que tradicionalmente se dava por meio da temática tradicional petrarquiana pelo louvor e enaltecimento da amada, no soneto inglês se desenrola em três variantes: sonetos religiosos ou filosóficos; de amor; e de louvor ao patrono. Nos sonetos shakespearianos, tal abrangência se dá em uma esfera muito maior, que trata desde temas mais provocativos e obscuros, até aqueles que expressam as mais variadas emoções. Collin (2008) assevera que, embora Shakespeare desenvolva suas temáticas nos sonetos estabelecendo uma coerência estrutural ${ }^{28}$, por outro lado, uma grande quantidade de sonetos expressa uma linguagem complexa e subverte não só a temática petrarquiana tradicional, mas também os modelos formais até então estabelecidos. Spiller (1992) destaca que, desde a publicação de Sidney em 1591, os poetas ingleses muitas vezes assumiam

\footnotetext{
${ }^{28}$ A coerência estrutural que se compreende aqui é explicada por Collin $(2008$, p. 212) "Os sonetos shakespearianos se desenvolvem com uma dinâmica emocional marcada por um jogo unificador de pensamento e linguagem [...]".
} 
uma postura antipetrarquizante e optavam por não seguir o padrão da linguagem cortês e petrarquiana que havia sido difundida no período elisabetano. Silva Ramos (2008) atesta também que essa postura já havia sido adotada pelo próprio Sidney em Astrophel and Stella, e sendo que os sonetistas seguintes nada mais fizeram do que repetir essa fuga dos métodos mais convencionais. Um exemplo disso, em Shakespeare, é o caso do soneto 147, em que o poeta compara o amor a uma doença. Com respeito ao modelo formal do soneto inglês, pode-se verificar também subversões realizadas pelo Bardo nos de número 99, 126 e 145; o primeiro é composto por 15 versos, o segundo é formado por 12 versos em dísticos de rimas emparelhadas, e o terceiro é constituído por rimas irregulares em tetrâmetros - versos de quatro pés. Sendo assim, é notório considerar que Shakespeare também contribuiu para o desenvolvimento do chamado soneto inglês, por conta da sua singular maneira de tratar essa forma poética. Vale mencionar que, quanto a sua tradução no Brasil, a ser discutida posteriormente, os tradutores ora tendem a valorizar uma prática poética do Bardo que pode ser vista até como subversiva e, portanto, esses profissionais se eximem de observar certos elementos do soneto, ora se atentam mais aos aspectos formais. Isso se verifica, por exemplo, em Wanderley (1991), que afirma que o soneto shakespeariano é um ser musical e, dessa maneira, deve-se buscar uma correspondência com os aspectos formais da obra lírica do poeta inglês, pois "o som de um decassílabo (no caso o pentâmetro iâmbico) não é o som de um dodecassílabo [...] da mesma forma que o som que Beethoven dá a um quarteto não é o que dá a um trio." (p. 19). Em contrapartida, a tradutora Thereza Christina Rocque da Motta afirma que Shakespeare transcende toda formalidade e, portanto, em suas traduções não há uma observância estrita aos elementos formais.

Os elementos semânticos e formais do soneto shakespeariano geralmente seguem o modelo desenvolvido por seus precedentes, Wyatt e Surrey. O soneto consiste em 14 versos decassilábicos que se dividem em três quartetos e um dístico final, desenvolvendo-se progressivamente em cada quadra e com o dístico que conclui o poema. O contrato métrico estabelecido 
logo no início de cada soneto é o pentâmetro iâmbico com rima cruzada, que se apresenta em um esquema regular de $a b a b c d c d$ efef $g g$. As exceções são encontradas nos sonetos 99, 126 e 145, como já abordado anteriomente. Cabe distinguir aqui o sistema de versificação do inglês e do português. Em língua inglesa a unidade prosódica é o pé, que admite um número limitado de sílabas - no caso de Shakespeare, o pentâmetro iâmbico é composto por cinco pés, com uma sílaba átona e uma tônica. Já em português, os versos se dividem em sílabas, sendo algumas átonas e outras acentuadas, portanto o ritmo no português se baseia em quantas sílabas átonas e tônicas compõem um poema, diferentemente do inglês, idioma no qual o que vale é o tipo de péque está sendo utilizado. Como o sistema do soneto shakespeariano contém cinco pés de duas sílabas cada, muitos tradutores creem que traduzindo-o em decassílabos alcançam uma correspondência formal. Por outro lado, há aqueles profissionais que optam pelos dodecassílabos, ou alexandrinos, para traduzir o pentâmetro iâmbico, justificando que a língua inglesa é mais sucinta do que o português, logo, a fim de reproduzir todas as ideias identificadas no original, isto é, buscar uma correspondência semântica, é necessário lançar mão de versos mais longos.

Em termos semânticos, a linguagem shakespeariana se destaca pelo uso de metáforas que normalmente abordam aspectos referentes à natureza, à morte, ao tempo, por exemplo; seja para ressaltar as qualidades do amado(a) (amigo), seja para aludir à hostilidade do tempo face ao homem, pois este é temporal e, logo, perecível. É o que a tradutora portuguesa Maria do Céu Saraiva Jorge (1962, p. 18) aponta em seu comentário acerca dos sonetos: "Shakespeare insiste na destruição causada pela 'foice' do tempo, mas também se refere às suas 'bênçãos"'. Dessa forma, os sonetos estão repletos de elementos metafóricos, antagônicos, dúbios e enigmáticos, que se combinam e se entrelaçam ao longo do poema até atingir o clímax que precede seu desfecho.

Há no Bardo diversos elementos consonantes e dissonantes com aqueles que o precederam. Assim como Petrarca, Shakespeare também 
lançou mão de diversos recursos linguísticos, tais como palavras polissêmicas, metáforas e ambiguidades, a nomear alguns, e se observa grande maestria, tanto por parte do sonetista italiano, quanto do inglês, no uso de tais recursos, sendo o recurso metafórico, por exemplo, um elemento primordial para toda a escrita poética (SPILLER, 1992). Ainda assim, um leitor inexperiente de Shakespeare, que desconhece o estilo de escrita desse poeta, poderá encontrar em seus sonetos metáforas que admitem interpretações das mais enigmáticas. Nesse sentido, o poeta inglês introduz em seus sonetos muitas imagens para explicar uma situação específica, como se observa no trecho do soneto 3 de Shakespeare, seguido da tradução de Jorge Wanderley (1991):

\author{
Sonnet 3 \\ For where is she so fair whose uneared womb \\ Disdains the tillage of thy husbandry? \\ Qual mulher, de ventre ainda infértil, \\ Que a tal marido recuse plantio?
}

Nesse trecho nota-se a imagem do plantio para incentivar a procriação, que é a essência de todo soneto 3 . Como consta no rodapé do tradutor e poeta Jorge Wanderley (1991), no inglês elisabetano, isto é, da época em que Shakespeare possivelmente produziu os seus sonetos, o vocábulo uneared assumia sentidos como "não arado" ou "não cultivado", em que o tradutor oportunamente emprega o adjetivo "infértil" para corroborar tal conotação já pretendida pelo Bardo. Além disso, evidencia-se o vocábulo husbandry, que exprime a ideia de agricultura ou pecuária, como define o dicionário MerriamWebster em sua plataforma on-line. Sendo assim, verifica-se que Shakespeare, assim como Petrarca, utiliza de diversos recursos linguísticos para projetar imagens múltiplas em seus sonetos e, dessa maneira, 
impulsionar os temas que abrangem uma realidade mais concreta. Vale salientar que o critério estilístico adotado pelo sonetista inglês é diferente daquele privilegiado por Petrarca. Enquanto Shakespeare se utiliza mais da semântica e acentua mais a projeção das ideias do cotidiano, o poeta italiano busca dar mais evidência ao antagonismo, ao caráter instável e momentâneo que caracteriza o soneto. Ambos, no entanto, tomam o soneto como a forma métrica mais rápida para alcançar o seu interlocutor. No que tange à estrutura sintática de Shakespeare, Jorge Wanderley observa que "cada statement pode abraçar o que antecede tanto quanto o que sucede, podendo valer para todos os níveis semânticos" (1991, p. 15), ratificando a ênfase nos aspectos imagéticos e semânticos do poeta inglês. Em contrapartida, Spiller (1992, p. 49) considera que "a sintaxe de Petrarca percorre seus sonetos, de maneira direta, na medida em que faz pouco uso de inversão para perturbar a ordem normal das palavras [...]"29, apontando que a forma estilística de Petrarca é mais sistemática, pois segue um percurso horizontal e progressivo, e menos enigmático.

É evidente que Shakespeare observou muitos dos elementos desenvolvidos por seus conterrâneos precedentes. O dístico final reinventado por Wyatt e a divisão da forma poética em três quadras e dístico adaptada por Surrey são exemplos de que o Bardo manteve a forma do chamado soneto inglês. Contudo, Collin (2008) afirma que o soneto shakespeariano se distingue do soneto inglês principalmente pelo seu desenvolvimento metafórico que recebe um desfecho, ora como forma de síntese das ideias, ora através de uma nova abordagem das imagens já aludidas. Isso ratifica a ideia de que o dístico utilizado por Shakespeare tem a função de concluir o poema, mas isso não significa afirmar que esse recurso tem por intuito estabelecer um equilíbrio conclusivo por meio de uma reflexão sábia, como verificado em Spiller (1992) e discorrido aqui anteriormente. Se por um lado Shakespeare lança mão das temáticas já desenvolvidas por seus

29 "Petrarch's syntax winds through his sonnets, straightforward in that he makes little use of inversion to disturb normal word order [...]" 
conterrâneos, por outro ele realiza sátiras acerca do moralismo exacerbado e dos estilos mais tradicionais adotados, reinventando a abrangência dos sonetos, como é o caso da figura feminina exaltada pelos sonetistas anteriores, que em Shakespeare é o Belo Jovem que recebe toda a devoção e admiração. A mulher, por sua vez, na figura da Dama Negra, é tida como objeto do desejo carnal do eu lírico, mas não do amor petrarquiano. Sua aparência é morena e seu cabelo, preto, o que difere do padrão europeu dos cabelos loiros e da pele branca. Durante certa altura, há um triângulo amoroso entre o eu lírico, o Belo Jovem e a Dama Negra que vai contra todo o moralismo inerente ao pensamento puritano elisabetano. Ademais, se na temática tradicional o patrono é enaltecido por seu incentivo financeiro, no Bardo essa figura é problematizada pela introdução do Poeta Rival, que na sua rivalidade por patrocínio, dificulta o ofício do eu lírico, que se sente ameaçado, com risco de perder a atenção do seu amado (amigo). Sendo assim, apresentar esses encontros e desencontros efetuados nos sonetos shakespearianos só reafirma a amplitude e a complexidade que a linguagem do poeta inglês consegue alcançar. 


\section{5 SHAKESPEARE EM TRADUÇÃO NO BRASIL: BREVÍSSIMO RELATO}

So long as men can breathe or eyes can see, So long lives this, and this gives life to thee.

WILLIAM SHAKESPEARE (sonnet 18)

Os primeiros registros da chegada de Shakespeare ao Brasil datam de meados do século XIX, com adaptações das línguas espanhola, portuguesa e francesa (HELIODORA, 2008). Pouco se tinha de contato com as peças e obras originais, o que acabou por favorecer encenações chamadas por Barbara Heliodora de "espetáculos pseudo-shakespearianos" (2008, p. 321). Em relação aos sonetos, publicaram-se muitos fragmentos e trechos esparsos nos primórdios de Shakespeare no Brasil, como assinala Martins (2008, p. 303).

As primeiras traduções dos sonetos do Bardo para o português do Brasil, segundo os registros disponíveis, foram feitas por Fontoura Xavier (1856-1922), poeta do parnasianismo (BOSI, 2015), em um livro intitulado Opalas. Na segunda edição do volume - dedicado à memória de seus pais, datado de 1905 - há a tradução dos sonetos 14, 17, 21 e 59, os dois primeiros em decassílabos e os dois segundos em dodecassílabos.

No século $X X$, deu-se início de fato à publicação de uma série de traduções brasileiras das peças shakespearianas diretamente da língua inglesa ${ }^{30}$, bem como dos sonetos; e a recepção no Brasil dessas primeiras traduções se deu de maneira positiva e em momento considerado propício, como bem aponta Gomes (1961, p. 36), uma vez que o cenário brasileiro ainda se constituía, enquanto literatura nacional. Esse panorama contribuiu para que as traduções fossem compreendidas como elitistas, empregando linguagem rebuscada e voltadas para um público-alvo bem específico. É o que afirma Vollet (1998, p. 76-77) acerca da perspectiva elitista: "adequaram-se, em sua

\footnotetext{
30 Segundo Martins (2020), considerando exclusivamente as traduções integrais publicadas em forma de livro, é possível contabilizar desde 1933, o marco inicial dessas traduções, com o Hamlet de Tristão da Cunha, 218 traduções brasileiras das 39 obras dramáticas de Shakespeare. Até o momento, 36 tradutores individuais, uma dupla e um coletivo assinaram traduções integrais de peças do cânone.
} 
maioria, as traduções brasileiras, que são eruditas e complexas, difíceis de serem lidas, acabando por excluir uma determinada parcela do público leitor". Portanto, seguindo essa ótica, diversas traduções repletas de complexos recursos linguísticos foram produzidas e veiculadas com um certo rótulo de leituras inacessíveis à maioria dos leitores da época. Nas últimas décadas do século $X X$, no entanto, Shakespeare passou a receber por parte de leitores, encenadores e tradutores um tratamento menos reverente, em parte por influência da maior liberdade política e estética vivida no Brasil. Como aponta a matéria produzida por Débora Ghivelder e Luiz Felipe Reis para o jornal $O$ Globo na ocasião da celebração do aniversário de Shakespeare: "a sensação de que ele era inalcançável, sacrossanto, despareceu nos últimos anos" (GHIVELDER \& REIS, 2014, p. 1). Os autores ainda comentam que o crítico teatral Macksen Luiz vai na mesma linha, ao afirmar que "[h]á 15 anos se pensava em montar Shakespeare como quem rende uma homenagem. Isso mudou" (ibid.). Pode-se dizer que a mesma atitude se aplica às traduções, como se pode observar na prática das tradutoras shakespearianistas Aimara da Cunha Resende e Beatriz Viégas-Faria, entre outros/as, além da própria Barbara Heliodora e de Millôr Fernandes. Segundo Aimara Resende, a obra de Shakespeare começou a atrair o interesse de acadêmicos na virada do século VIII para o XIX, e assim ficou com a equivocada fama de erudita. "Ele [Shakespeare] era um escritor popular. Fazia peça para o povo e não era só para a nobreza", ressalta Resende (apud BRAGA, 2020, n.p.), que luta incansavelmente para simplificar a imagem elitista criada em torno do dramaturgo.

É notório que as peças teatrais do Bardo são, em larga escala, traduzidas e investigadas por críticos brasileiros de maneira muito mais vasta do que seus sonetos, que, embora traduzidos em uma quantidade considerável, não têm merecido tantas análises aprofundadas. É, portanto, de principal interesse neste trabalho lançar luz sobre as traduções brasileiras dessa produção lírica e também sobre os tradutores que as realizaram ao 
longo de quase 12 décadas, inserindo-os em seus respectivos contextos temporais e socioculturais.

\section{1}

\section{A tradução dos sonetos para o português do Brasil}

As traduções dos sonetos de Shakespeare no Brasil ocorrem em diferentes épocas e conjunturas, sendo preciso analisá-las para identificar os métodos e técnicas utilizados por cada tradutor. Entende-se que, devido a fatores externos e internos, as traduções e retraduções podem ser bastante distintas em termos de objetivos, estratégias e efeitos, respondendo a demandas e coerções estilísticas, ideológicas e comerciais, dentre outras.

Seguindo essa ótica, o mapeamento aqui feito privilegiará a análise da figura do tradutor contemplando, sempre que possível, os paratextos e os metatextos, como já mencionado no início desta dissertação. Além disso, será considerado o contexto literário de publicação da obra traduzida, procurando verificar o lugar e o status que as diferentes traduções e tradutores ocuparam ou ocupam no cenário da lírica shakespeariana em tradução no Brasil.

A respeito do critério de organização dos tradutores dispostos neste trabalho, optou-se por ordená-los cronologicamente pela data da publicação de seus volumes traduzidos, a fim de esquematizá-los como um contínuo. Ressalve-se, no entanto, que o corpus reunido inclui as traduções e tradutores brasileiros que puderam ser localizados, não havendo como garantir que seja um levantamento absolutamente completo. Esse recorte foi possível através de consultas a paratextos dos sonetos traduzidos, como o prefácio do livro de Jorge Wanderley (1991), assinado pelo próprio tradutor; o posfácio do livro de Ivo Barroso (2015), escrito por Nehemias Gueiros; a dissertação de mestrado de Walker (2018), desenvolvida na Universidade de Brasília, que registra traduções brasileiras dos sonetos desde o século XIX até as mais recentes publicações; e também a partir de buscas em editoras. 
Sendo assim, elencam-se aqui 18 tradutores que tiveram suas traduções dos sonetos publicadas no Brasil, seguindo a ordem cronológica das publicações originais:

1. Fontoura Xavier foi o primeiro tradutor para o português do Brasil dos sonetos de Shakespeare. O volume intitulado Opalas, publicado em Lisboa pela editora Viúva Tavares Cardoso, em sua segunda edição (1905) traz a tradução de quatro sonetos por Xavier (14, 17, 21 e 59), que os dedicou à memória de seus pais;

2. Samuel MacDowell Filho, mestre pela Faculdade de Direito do Recife, em 1952 publicou a tradução de 83 sonetos dos 154 de Shakespeare pela editora Jornal do Brasil sob o título de Pequena sequência shakespeariana, segundo aponta Nehemias Gueiros (2015);

3. Péricles Eugênio da Silva Ramos traduziu e organizou um total de 45 dos 154 sonetos. Em 1953, publicou 33 sonetos pela editora Saraiva; em 1966, pela Edições de Ouro; depois pela Ediouro (s/d), com o acréscimo de mais 12 sonetos, totalizando 45; posteriormente em 1970, pela Civilização Brasileira; e em 2008, pela editora Hedra ${ }^{31}$;

4. Jerônimo de Aquino traduziu todos os 154 sonetos, que foram organizados e prefaciados por Carlos Alberto Nunes e publicados em 1956 pela editora Melhoramentos em formato bilíngue e, posteriormente, lançados em uma segunda edição monolíngue em 2007, pela editora Martin Claret;

5. Flora Machman publicou a tradução de um único soneto shakespeariano, o de número 27 , em 1964, em edição comemorativa do quarto centenário do nascimento de Shakespeare (MELLO; MONAT, 1964, p. 61);

6. Geir Campos, poeta e tradutor, publicou a tradução de dois sonetos, os de números 25 e 116, em 1964, na mesma edição que Flora Machman

\footnotetext{
31 A editora Hedra assinala em seus dados catalográficos que a segunda edição do volume é da Civilização Brasileira, publicada em 1970, mas segundo os dados levantados aqui, essa informação não procede. Há ainda uma possível republicação de 2012 pela editora Hedra. Houve contato por e-mail para esclarecer tais dados, mas sem sucesso.
} 
(MELLO; MONAT, 1964, p. 141). Segundo Gueiros (2015), Geir Campos foi um "esplêndido poeta e mestre de poética" (p. 152);

7. Oscar Mendes, tradutor pernambucano, traduziu todas as obras líricas de Shakespeare, inclusive os 154 sonetos, em edição da Nova Aguilar datada de 1969. Encontram-se no terceiro e último volume de William Shakespeare - Obra Completa, que traz a lírica do autor inglês ao lado dos dramas históricos, estes traduzidos conjuntamente por Mendes e F. Carlos de Almeida Cunha Medeiros. A edição é monolíngue e com capa dura, em papel bíblia;

8. Guilherme Figueiredo, tradutor e professor, traduziu apenas sete dos 154 sonetos shakespearianos $(22,23,55,66,71,91$ e 130), sendo que os de número 22, 23 e 71 foram publicados no Rio de Janeiro pelo Jornal de Letras, em 1971. Já os demais foram lançados dois anos mais tarde, em 1973, pela editora Cátedra;

9. Ivo Barroso, escritor, poeta e tradutor, reuniu em um volume a tradução de 24 sonetos, os quais foram publicados em 1973 pela editora Nova Fronteira. Em 1975, pela mesma editora, houve a publicação da $2^{\text {a }}$ edição, com o mesmo número de sonetos já traduzidos. A seguir, houve uma $3^{a}$ edição, em 1991, também pela Nova Fronteira, com 30 sonetos; uma 4ª edição, em 2005, com 42 sonetos; e, por fim, uma $5^{\text {a }}$ e definitiva edição em 2015, com um total de 50, pela mesma editora;

10.Jorge Wanderley, poeta, tradutor e estudioso da poesia, traduziu integralmente os 154 sonetos, publicando-os em formato bilíngue em 1990, pela editora Civilização Brasileira. Houve a publicação da segunda edição em 1991, pela mesma editora, em formato similar à primeira; e recentemente, em 2019, verifica-se a publicação de uma terceira edição organizada por Ivan Pinheiro Machado e publicada pela L\&PM, seguindo os mesmo formatos e notas de rodapé das edições anteriores;

11. Barbara Heliodora, especialista em Shakespeare, crítica de teatro e referência de estudo do Bardo no Brasil, publicou um volume em 
formato de bolso com a tradução de 19 sonetos em conjunto com sua mãe, Anna Amelia de Queiroz Carneiro de Mendonça, sob o título de Poemas de Amor - William Shakespeare (Ediouro, 2000);

12. Renata Cordeiro, tradutora e acadêmica, publicou 17 sonetos dos 154 de Shakespeare sob o título de Sonetos ao Jovem Desconhecido pela editora Landy, em 2003. Na obra traduzida há, além dos sonetos, a cena dois do segundo ato de Romeu e Julieta ${ }^{32}$ e algumas notas explicativas para ambas traduções. Além disso, em 2001, Cordeiro publicou a tradução do soneto 3 no periódico da USP Cadernos de Literatura em Tradução; depois, em 2003, o de número 4; em 2005, publicou tanto a cena de Romeu e Julieta como os sonetos 5, 6, 7 e 8 . Já em 2006, publicou os sonetos 9, 10, 11, 12 e 13, também em Cadernos de Literatura em Tradução, seguindo um formato bilíngue;

13. Milton Lins traduziu os 154 sonetos de Shakespeare no volume Sonetos de William Shakespeare, que publicou por conta própria, sem o auxílio de uma editora, em 2005. Posteriormente, em 2010, recebeu o prêmio ABL de tradução da Academia Brasileira de Letras pelo livro Pequenas Traduções de Grandes Poetas (também por edição própria), lançado em 2006, onde constam algumas de suas traduções do Bardo;

14. Thereza Christina Rocque da Motta publicou 44 sonetos pela sua editora, Ibis Libris, em 2006. Mais tarde, em 2009, devido à comemoração dos 450 anos da primeira publicação dos sonetos shakespearianos, publicou os 154 sonetos de maneira integral, pela mesma editora;

15. Geraldo Carneiro publicou em 2012 pela editora Nova Fronteira, fragmentos de textos de Shakespeare em $O$ discurso do amor rasgado - poemas, cenas e fragmentos de William Shakespeare, uma seleta na qual o tema central é o amor. Nela, além de traduções de trechos de algumas peças, há cinco sonetos $(76,18,15,65,116$, segundo sua ordem), apresentados em formato bilíngue e em linguagem mais

${ }^{32}$ Cena que se passa no jardim dos Capuleto, na qual Romeu corteja Julieta às escondidas. 
coloquial, com algumas notas críticas dos fragmentos traduzidos após o posfácio;

16. Oscar Dourado, professor emérito da Universidade Federal da Bahia, onde atuou nas áreas de Artes, com ênfase em música, traduziu e publicou os 154 sonetos de Shakespeare em 2017, pela P55 Edições. O volume é estruturado por uma apresentação em forma de notas introdutórias e com as traduções em formato monolíngue;

17. Almiro Pisetta publicou em 2018 a tradução dos 154 sonetos de Shakespeare em formato bilíngue e de capa dura, pela editora Martin Claret. As traduções são em verso e prosa, acompanhadas de várias notas de rodapé explicativas. Além disso, observa-se uma robusta introdução em que Pisetta apresenta suas noções e estratégias tradutórias;

18. Elvio Funck, tradutor de 21 obras dramáticas de Shakespeare, tais como Romeu e Julieta (2012), Otelo (2015), Rei Lear (2013), entre outras, publicou em 2019 a tradução dos 154 sonetos de Shakespeare em tradução livre, interlinear e em formato bilíngue, pela editora Movimento. Além disso, no verso da página de cada soneto traduzido se encontram notas explicativas e outras traduções do dístico final em língua portuguesa, francesa e alemã.

É importante mencionar que a descrição e análise dos sonetos traduzidos a ser apresentada no capítulo seguinte também incluirá um volume traduzido intitulado por Sonetos de Shakespeare: faça você mesmo, organizado por Jorge Furtado em conjunto com Liziane Kugland, em 2010. Os sonetos foram traduzidos por diversos artistas brasileiros, tais como Lázaro Ramos, Clarice Falcão e Fernanda Torres, entre outros. A publicação ficou a cargo da editora Objetiva, e todos os direitos autorais da obra foram doados ao UNICEF. O que torna essa edição diferente das demais é que oferece um prefácio didático voltado para o público não familiarizado com Shakespeare e 
convida os leitores a realizar suas próprias traduções dos sonetos no verso de cada página, o que corrobora a proposta explicitada no título da obra. 


\title{
6 \\ A DIFUSÃO DE THE SONNETS NO BRASIL: TRADUTORES E TRADUÇÕES
}

\author{
So oft have I invoked thee for my Muse, \\ And found such fair assistance in my verse, \\ As every alien pen hath got my use, \\ And under thee their poesy disperse. \\ WILLIAM SHAKESPEARE (sonnet 78)
}

Neste capítulo, será esboçada uma história das traduções dos sonetos shakespearianos transpostos para o português do Brasil que tenham sido publicadas em volumes ou veículos impressos. A proposta, como já mencionada, é construir essa história a partir dos tradutores, vistos individualmente: quem são eles; qual a sua formação; quantos e quais sonetos traduziram; qual é a sua relação com a tradução e, especificamente, com a tradução da obra lírica shakespeariana; qual é a sua concepção de tradução, que pode ser revelada ou inferida por meio de declarações por eles feitas em paratextos e metatextos; que estratégias tradutórias globais empregaram; quais as editoras que publicaram suas traduções, e em que formato; em que momento histórico foram realizadas essas traduções, e em que contexto estético. Além disso, é de interesse também verificar se um determinado profissional traduziu a obra lírica dos sonetos apenas como uma atividade episódica, que não teve continuidade, ou se o tradutor em questão já havia realizado traduções do poeta inglês em outras ocasiões.

Em relação às estratégias tradutórias globais, o que se verificará serão os recursos adotados, verso branco, versos em decassílabos (dez sílabas), em dodecassílabos (doze sílabas), formato shakespeariano 4-4-4-2, entre outros aspectos que fazem parte dos dados levantados, assim como opções editoriais concernentes à apresentação das traduções: se interlineares, em edições bilíngues ou em edições monolíngues, e com ou sem aparato crítico. Todas essas informações são exibidas em um quadro panorâmico que se encontra na forma de apêndice a este trabalho.

É notório ainda salientar, antes mesmo da apresentação abaixo, dois pontos que valem ser esclarecidos: grande parte dos tradutores analisados 
traduziram os sonetos shakespearianos e os publicaram em formato livro, mas há uns poucos que publicaram em jornais. Esse meio não foi desconsiderado, uma vez que cabe levar em conta outras esferas nas quais os sonetos shakespearianos circularam em tradução. Outro ponto é o momento literário em que os volumes traduzidos se inserem. Esse dado é relevante por viabilizar a contextualização da tradução, permitindo que se verifique se um tradutor em questão aderiu às normas literárias vigentes no sistema receptor ou se optou por subvertê-las. Contudo, não cabe aqui versar extensamente sobre as escolas literárias brasileiras, seus temas e características, mas apenas pontuar em qual momento do sistema literário brasileiro as diferentes traduções dos sonetos shakespearianos se inserem e tentar verificar se esse contexto influi diretamente na tradução.

Em se tratando do momento literário brasileiro atual conhecido como pós-modernismo, vale destacar a complexidade de se discutir o termo, pois se entende "pós-modernismo" em várias esferas, sobretudo como um conceito que pode ser lido como uma negação de pressupostos epistemológicos universalizantes (MORICONI, 2002). O que se pretende fazer aqui é tentar caracterizar as traduções que se inserem nesse momento, bem como aquelas situadas em contextos literários anteriores, dentro das tendências estéticas da poesia brasileira - sem desconsiderar o fato de que no pós-modernismo não há um estilo predominante mas, sim, uma multiplicidade de estilos que convergem entre si.

Estudiosos da poesia tendem a concordar que, no que tange à caracterização da poesia no pós-modernismo, seja necessário adotar uma postura distinta daquela assumida para definir os padrões estéticos dos movimentos literários anteriores (HOLLANDA, 1998; BRITTO, 2013; CAPELA, 2006). Tal consenso decorre da avaliação de que já não é uma perspectiva que se baseie somente na observação de preferências formais e ideológicas desse ou daquele sistema literário, mas sim, a parafrasear Britto (2013), uma análise individualizada de cada poeta e de seu trabalho pelo que ele é, não como um estilo que represente um movimento literário específico. Isso se dá 
pelo aspecto recorrente na poesia atual que é a pluralidade de vozes, de formas e de temas - ou, como entende Hollanda (1998, p. 20), "hibridização de formas e fronteiras no campo da produção cultural”. Esses aspectos serão levados em conta ao verificar em qual momento literário uma tradução se insere. Entretanto, como este trabalho é de cunho historiográfico e descritivo, tendo por objetivo apresentar um percurso dos tradutores e das traduções dos sonetos de Shakespeare no Brasil, a metodologia adotada para verificar se a produção tradutória de um dado profissional se aproxima ou não de um momento literário será uma aferição breve da correspondência desses trabalhos com a ideologia e os aspectos formais dominantes naquele tempo, apresentando os aspectos gerais de cada tradutor e de suas respectivas traduções. Trata-se, portanto, de um estudo panorâmico, mais horizontal do que vertical; foge do seu escopo analisar detidamente as traduções de todos os tradutores identificados, contemplando seus diferentes aspectos. Tal impossibilidade significa que há um vasto campo a explorar por parte de outros pesquisadores, diante do volume do corpus que todas as traduções brasileiras do 154 sonetos shakespearianos representam.

\section{Antônio Vicente da Fontoura Xavier (1856-1922) ${ }^{33}$}

Antônio Vicente da Fontoura Xavier nasceu do Rio Grande do Sul em 1856, e faleceu em 1922, em Portugal. Foi um atuante diplomata brasileiro e considerado o pioneiro no que diz respeito à tradução dos sonetos shakespearianos para o português do Brasil. Colaborou em periódicos no Rio de Janeiro entre os anos de 1874 e 1891, e traduziu obras de grandes nomes como Edgar Allan Poe, Charles Baudelaire e Thomas Foley, entre outros, como aponta Aleixo (2011).

Poeta parnasiano, Fontoura Xavier publicou em 1884 a primeira edição do volume Opalas; contudo, verifica-se que os sonetos de Shakespeare

\footnotetext{
${ }^{33}$ Cabe comentar aqui que, por uma razão estética, o padrão adotado para informar o ano do nascimento e morte valerá somente para aqueles tradutores/as que já tiverem falecido.
} 
traduzidos só foram inseridos na $2^{\text {a }}$ edição ${ }^{34}$, de 1905 . Os primeiros dois sonetos (14 e 17) foram transpostos na forma dos decassílabos; e os dois últimos (21 e 59), em dodecassílabos. Curiosamente, a métrica segue a camoniana, de duas quadras e dois tercetos, e as rimas estão em um esquema não tão regular: no soneto 14 estruturam-se $a b a b$ bccb dbd ebe; no 17, abba acca dde ffe; no 21, abba acca bdb ede; e no 59, abba baba ccd eed. Assim, Xavier opta por adotar uma estrutura do sistema receptor, "aclimatando" o soneto em termos formais, em vez de manter a forma do soneto elisabetano. Além disso, o esquema rímico não regular é mais uma evidência de que o tradutor não busca aderir de forma rigorosa às normas estilísticas e formais do texto de origem. Vejamos o soneto 14 no original ${ }^{35}$, seguida da tradução de Xavier, preservando os elementos ortográficos, acentos e pontuações da época em que foi publicado:

\section{Sonnet 14}

Not from the stars do I my judgement pluck, And yet methinks I have astronomy,

But not to tell of good or evil luck, Of plagues, of dearths, or seasons' quality;

Nor can I fortune to brief minutes tell, Pointing to each his thunder, rain and wind, Or say with princes if it shall go well

By oft predict that I in heaven find:

But from thine eyes my knowledge I derive, And, constant stars, in them I read such art As truth and beauty shall together thrive If from thy self to store thou wouldst convert:

Or else of thee this I prognosticate, Thy end is truth's and beauty's doom and date.

\footnotetext{
34 Há, ao todo, cinco edições do volume Opalas, segundo Aleixo (2011, p. 40). Nesse artigo, além de aprofundar-se sobre a vida e atuação de Fontoura Xavier, o autor tece breves comentários acerca das edições publicadas.

35 Optei por inserir todo o soneto, em vez de um trecho, como será feito daqui em diante, a fim de garantir que o leitor visualize de maneira integral todos os elementos que compõem a tradução de Xavier.
} 
Eu não sei ler a sorte em astrolabios,

E nem predigo pela astrologia

A fome e a peste como uns tantos sabios,

Mas entretanto sei astronomia.

Um destino qualquer eu não leria;

Se houvesse por ventura o estranho fado

A ler de um rei ou principe de estado,

Bofé! que ao certo ler não saberia.

E' que em duas estrellas eu resumo

(Teus olhos) toda a minha astronomia;

$E$ tanto leio nelles, que presumo

Que foste filha de um cinzel antigo,

E o dia em que morreres, nesse dia

Morre na terra a plastica comtigo.

O Parnasianismo - corrente literária à qual o poeta se uniu - é considerado um movimento antirromântico (BOSI, 2015), resgatando não só uma herança classicista, em seu rigoroso culto aos aspectos formais da poesia, mas também um ideal de perfeição estética, que rompe com a perspectiva de uma produção a partir da inspiração, observada no Romantismo. Esse estilo parte da razão no que tange à produção, ou seja, a realização de um trabalho se dá primeiramente por meio do intelecto (PEIXOTO, 2010). Todavia, vale dizer que a publicação da $2^{\mathrm{a}}$ edição (1905), que contém as traduções shakespearianas situa-se no pré-modernismo período que vai do início do século até a Semana de Arte Moderna em 1922. A esse momento literário de transição, Bosi (1969, p. 11) atribui duas compreensões possíveis: uma conotação puramente "temporal de 
anterioridade" (ibid.), representada pelo prefixo pré, que abriga as produções dos neos (neoparnasianismo e neosimbolismo); já na segunda acepção, dessa vez, mais estética, tais prefixos ilustram "um sentido forte de precedência temática e formal em relação à literatura modernista" (ibid.), isto é, uma antecipação estética de propostas modernistas. Nesse sentido, o chamado pré-modernismo prenuncia temas e aspectos formais abordados a partir de 1922.

Pode-se dizer, no entanto, que as traduções dos sonetos shakespearianos realizadas por Fontoura Xavier - embora cronologicamente situadas no pré-modernismo - não anunciam ideais modernistas, visto que o tradutor opta pela forma de versificação portuguesa, permitindo-se o uso da linguagem refinada, por vezes castiça, como empregada pelos grandes parnasianos da época em que viveu: Olavo Bilac (1865-1918), Alberto de Oliveira (1857-1937) e Raimundo Correia (1859-1911).

\section{Samuel MacDowell Filho (19-? - 19-?)}

Sobre esse tradutor se encontram poucos registros, isso significa dizer que as informações sobre sua vida e obra tiveram como fonte exclusiva os estudos de Gueiros (2015) e de Wanderley (1991), bem como os Anais da Biblioteca Nacional.

Educado na Inglaterra e França, Samuel MacDowell Filho foi mestre em Direito e professor da Faculdade de Direito do Recife, tendo traduzido em um volume 83 dos 154 sonetos do Bardo (de 1 a 20; 23, 26 a 30; 32, 33, 37, 40, 42 a $47 ; 50,51,53,54,61,66$ a $68 ; 71$ a $73 ; 76,79,81,86,87,89,90,94,97$, $98,100,104,106,107,109,111,116,119,121,123,126$ a 133; 138, 141 a $145 ; 147$ e 153) que foi publicado em 1952 pela editora Jornal do Brasil (GUEIROS, 1952). Ao que parece, sua publicação episódica - pois não houve outras traduções de Shakespeare feitas pelo autor - se constitui toda em decassílabos rimados e com linguagem erudita, como aponta Wanderley (1991), aludindo a uma concepção de Shakespeare como uma figura solene. Ele ainda assinala que MacDowell tinha grande aptidão em ambos os pares 
de idiomas, mas "pouco pulso poético" (p. 21), e ressalta que a noção de Shakespeare como um nobre diverge do "real" Bardo, que usava de maneira magistral uma linguagem mais simples e direta.

Ao se considerar a afirmação de Wanderley (1991) e as diversas metáforas encontradas nas obras líricas e dramáticas do poeta inglês, atestase que de fato Shakespeare apresentava grande aptidão linguística (SMITH, 2008) e que talvez, diante da forma mais concisa do soneto, o leitor perceba um discurso mais direto, digno de exceções. Entretanto, optar por não observar tais características não constitui necessariamente uma divergência com a ideia "real" do Bardo, segundo assevera Wanderley (1991), pois conforme ele próprio afirma, a tradução envolve um jogo de negociação de elementos. Seguindo essa ótica, pode-se dizer que cada tradução espelha aquilo que é "real" em Shakespeare, condizendo com as opções tradutórias de cada tradutor. Ademais, Elvio Funck (2019) exprime que a cada nova tradução, melhor se conhece Shakespeare, o que leva a compreender que não há uma noção absoluta, mas que cada ótica se complementa.

O momento literário preponderante em que o volume traduzido foi publicado é da geração de 45, que se estende até mais ou menos o ano de 1960. Essa geração de poetas neoparnasianos pregava uma volta a uma linguagem mais solene e aos aspecto formais da poesia (BRITTO, 2013). Por causa das poucas evidências, não se pode atestar que o tradutor esteve ligado ao movimento da geração de 45 , nem mesmo verificar em seus paratextos ou traduções suas noções e estratégias tradutórias. Todavia, ao investigar os dados salientados por outros estudiosos, como Gueiros (2015) e Wanderley (1991), acerca das traduções dos sonetos shakespearianos realizadas por MacDowell, observa-se uma aproximação com a estética poética do momento literário vigente no Brasil, pois opta por uma linguagem mais erudita e pela correspondência com os aspectos formais do original. 


\section{Péricles Eugênio da Silva Ramos (1919-1992)}

Nascido em São Paulo, Silva Ramos foi tradutor, poeta, crítico literário, antologista e filólogo. Estudioso da poesia, recebeu em 1946 o prêmio Fábio Prado pela publicação de Lamentação Floral, seu primeiro livro de poesia. Colaborou com o jornal O Estado de São Paulo no Suplemento Literário a partir de 1964, onde se tornou um dos críticos mais importante do país (RAMOS, 2008, p. 5). Foi idealizador e fundador do Museu de Arte Sacra, do Museu da Casa Brasileira e do Museu da Imagem e do Som. Foi uma das figuras da "geração de 45", que defendia a retomada do rigor formal, sobretudo das formas fixas, abolidas pelo modernismo radical dos poetas dos anos de 1920 e 30, como será visto adiante. Muito atuante nos estudos da poesia brasileira, publicou diversas antologias que cobriam desde a poesia barroca até a poesia moderna, além de ser responsável pela organização da obra poética completa de Álvares de Azevedo. Vale salientar que Silva Ramos também conhecia profundamente latim, grego clássico, inglês, francês e alemão. Dentre suas traduções de famosos escritores como Byron, Virgílio, Melville e tantos outros, também traduziu três obras dramáticas de Shakespeare, Otelo, Macbeth e Hamlet, todas publicadas, sendo que a última recebeu menção honrosa da Royal Shakespearean Society (RAMOS, 2008, p. 5).

Silva Ramos traduziu, ao todo, 45 dos 154 sonetos shakespearianos, publicando-os por meio de editoras distintas. Primeiramente, houve a publicação, pela Saraiva (1933), de apenas 33 desses sonetos traduzidos, ordenados pelo tradutor em uma sequência distinta da estabelecida pelo editor do volume de 1609. A edição da Saraiva tinha formato de bolso e vinha acompanhada de ilustrações e iconografia, segundo atesta Gueiros (2015); posteriormente, a segunda publicação pela Edições de Ouro (1966) segue o mesmo formato da edição anterior, também de ordenação pessoal, com iconografia, ilustrações e em formato de bolso. Na sua terceira edição, pela Ediouro ( $\mathrm{s} / \mathrm{d})$ em formato de bolso, há um acréscimo de 12 sonetos 
traduzidos, ${ }^{36}$ totalizando assim 45 (WANDERLEY, 1991). Em 1970, houve uma quarta publicação pela editora Civilização Brasileira, contendo 45 sonetos em formato bilíngue; e a quinta edição, de 2008, organizada e publicada pela editora Hedra em formato de bolso e bilíngue, sem iconografia ou ilustrações, manteve as diversas notas de rodapé bem explicativas para cada soneto.

Todas as edições apresentam na sua introdução um estudo detalhado sobre Shakespeare e também do contexto jaimesco (1603-1625), em que veio a lume a primeira publicação do original na Inglaterra de 1609, além de explicações desde a entrada dos sonetos na Inglaterra do século XVI até a publicação dos sonetos shakespearianos editados por Thomas Thorpe. Ainda na introdução, o tradutor faz uma análise dos sonetos do Bardo, apresentando o padrão observado pelo inglês, e discorre acerca de questões como a data dos sonetos, as distintas figuras enigmáticas que se encontram nos sonetos como o Poeta Rival, a Dama Negra e o Belo Jovem, bem como as fontes nas quais Shakespeare possivelmente tenha se inspirado, rendendo um total de 36 páginas de análises introdutórias, excetuando a folha de rosto, o sumário e os dados biográficos do Bardo e de Silva Ramos.

É nessa mesma seção que se encontram algumas das afirmações de Silva Ramos a respeito de suas concepções sobre tradução e sobretudo acerca da tradução de poesia, valendo mencionar algumas. Logo no início da introdução, o tradutor assevera que é impossível manter todos os elementos de uma língua estrangeira quando se realiza uma tradução para o português, principalmente em se tratando de poesia, que se constitui de elementos formais e semânticos. Para ele, traduzir é acima de tudo compreender, e assinala que o profissional da tradução deve se apegar principalmente ao sentido. Mas ressalva que $\mathrm{o}$ ato de compreender é subjetivo, e não há como assegurar um entendimento exato ou completo, principalmente em se tratando de poesia. Essa compreensão, de que afirma Silva Ramos, parece estar vinculada a uma perspectiva de tradutor como leitor, como afirma Subirat

\footnotetext{
${ }^{36}$ Wanderley (1991) não menciona quais foram os sonetos inseridos na terceira edição de Silva Ramos. Também não foi possível obter o volume referido. Logo, não se teve registros de quais foram acrescidos na edição em questão.
} 
(1945 apud CAMPOS, 1992) "Traduzir é a maneira mais atenta de ler". Essa ótica também é vista nos paratextos de Oscar Mendes e de Thereza Christina Rocque da Motta, pois, segundo eles, o objetivo foi traduzir os sonetos de Shakespeare a partir da sua compreensão do texto lido na língua de partida, vertendo-os da maneira que os sentiam. Silva Ramos (2008), sobretudo, afirma que traduzir poesia exige, inevitavelmente "recriar, empreender uma aventura de compreensão e reexpressão de determinado texto" (p. 9), e continua, "Não há traduções exatas, há, isto sim, reexpressões algumas vezes felizes de texto estrangeiros" (ibid.).

Seguindo essa ótica, a tradução lida com o infortúnio de sacrificar itens para evidenciar outros, e no caso de Silva Ramos, o "sentido é indiscutível" (p.15), diferentemente de Wanderley (1991), que entende os aspectos semânticos através de uma relação de negociação. Sendo assim, Silva Ramos explicita sua opção pelo hexâmetro iâmbico, ou seja, o dodecassílabo (verso de doze sílabas), de acentuação, por via de regra, nas sílabas pares, com a justificativa de "não sacrificar muita coisa do texto" (RAMOS, 2008 p.12), já que há na língua inglesa um acervo maior de palavras monossilábicas. Além disso, ele adota em suas traduções os mesmos esquemas de rimas do inglês, abab cdcd efef gg, com algumas alterações, ora de natureza semântica, ora formal, e não se exime, em momentos pontuais, de adicionar alguns vocábulos não dispostos no soneto original. Segue a primeira quadra do soneto $18 \mathrm{em}$ inglês e a tradução de Silva Ramos:

\section{Sonnet 18}

Shall I compare thee to a summer's day?

Thou art more lovely and more temperate:

Rough winds do shake the darling buds of May,

And summer's lease hath all too short a date:

A um dia de verão como hei de comparar-te?

Vencendo-o em equilíbrio, és sempre mais amável:

Em maio o vendaval ternos botões disparte,

E o estio se consome em prazo não durável; 
Vale mencionar que suas traduções dos sonetos talvez sejam das mais conhecidas, uma vez que o próprio estudioso de Shakespeare no Brasil, Eugenio Gomes, o menciona como referência para as traduções dos sonetos do Bardo.

$\mathrm{Na}$ época de sua produção, o contexto no qual Silva Ramos se situa é o da terceira fase do modernismo, o que significa dizer que havia uma busca pelo resgate da ordem métrica e a obediência à versificação. Silva Ramos é citado por Alfredo Bosi (2015) como um dos poetas daquele período que soube encontrar "felizes soluções rítmicas para as traduções dos sonetos de Shakespeare" (p. 254). Esse momento literário se caracteriza por uma reação de oposição à primeira fase do modernismo, que estava orientada à produção em verso livre. Portanto, reivindicava-se a restauração da disciplina e da ordem que haviam sido abolidas (BOSI, 2015). Se por um lado Silva Ramos aderiu, em suas traduções, à poética de formas fixas predominante no sistema receptor, por outro a sua opção pelos versos dodecassílabos distancia-se da métrica que corresponde ao pentâmetro iâmbico do inglês, ao se considerar o que diz Wanderley (1991) acerca dos decassílabos, forma que mais se aproxima do esquema de versificação da língua de partida.

\section{Jerônimo de Aquino (19-? - 19-?)}

Ao investigar sobre a vida, atuação e obras publicadas de Jerônimo de Aquino, verifica-se que há poucos registros. As únicas informações que se têm desse quase invisível tradutor foram feitas pela tradutora e historiadora Denise Bottmann (2008) em seu blog Não gosto de plágio, que são: 1) Jerônimo de Aquino foi um poeta que traduziu integralmente os 154 sonetos do Bardo; 2) lecionou na escola normal de Guaratinguetá por volta de 1940; 3) suas traduções não se encontram em domínio público; 4) em sua primeira edição, os sonetos foram organizados em formato bilíngue e traduzidos em versos de doze sílabas, porém mantendo o esquema rímico shakespeariano. 
No material que se pôde localizar, Jerônimo de Aquino é aludido como um tradutor que verteu integralmente os 154 sonetos de Shakespeare, os quais foram publicados originalmente pela editora Melhoramentos. Quanto à data da primeira publicação, há divergências, pois alguns comentaristas afirmam ser 1956, outros 1957. Todavia, Gueiros (2015), Pisetta (2018) e Bottmann (2008) salientam que a publicação data de 1956, incluída na série Obras Completas de Shakespeare, vol. XXII, da editora mencionada. Crê-se, portanto, que seja essa a data da primeira publicação. Posteriormente, a editora Martin Claret coordenou o projeto de reedição da obra, publicando-a em 2007, em formato de bolso e monolíngue, cujo intuito era compor a coleção "A Obra-Prima de Cada Autor", como apontado no prefácio do volume, assinado pelo editor. Nesse paratexto, a editora defende a importância do livro e do ato de ler, bem como apresenta uma breve história do livro, referido como o "espelho da sociedade" (2007, p. 6). Ainda nessa edição, as 154 traduções são precedidas de uma breve introdução e contextualização dos sonetos shakespearianos na Inglaterra, considerando a época em que foram primeiramente publicados por Thomas Thorpe (1609), de autoria do poeta e tradutor Carlos Alberto Nunes, que traduziu a obra teatral completa de Shakespeare na década de 1950. Vale frisar que o mesmo paratexto acompanha a primeira edição dos sonetos traduzidos por Aquino, na mesma década, como mencionado acima.

A tradução dos sonetos por Aquino foi feita em dodecassílabos, assim como as de Silva Ramos, e seguiu um esquema rímico aproximado aos sonetos shakespearianos, abab cdcd efef gg. Há uma preferência do tradutor por vocábulos mais arcaicos e estruturas pouco usuais a um leitor comum, como poderá ser observado adiante.

Além de inversões e léxico arcaizante, as traduções estão repletas de metaplasmos ${ }^{37}$, o que desloca o acento e o ritmo presentes nos sonetos, como

\footnotetext{
37 Mudanças fonéticas na língua através do aumento, supressão, transposição do fonema de um dado vocábulo, concebendo assim uma variante para o termo, p.ex.: ainda > inda (Aférese - metaplasmo por supressão); soar > assoar o nariz (Prótese - metaplasmo por aumento). Desconsidera-se aqui o critério de certo ou errado.
} 
bem afirma Gueiros (2015). Vale pontuar aqui que Shanta Walker, em sua dissertação (2018, p. 29), menciona o seguinte: "Jerônimo de Aquino, utilizando versos mais longos, cria um poema fluido e eloquente.". Tal comentário produz uma expectativa de facilidade na leitura dos sonetos. Entretanto, basta examinar os que foram traduzidos por Aquino para se atestar a sua complexidade na leitura, como ilustra a primeira quadra do soneto 106 no original, seguido da tradução:

Sonnet 106

When in the chronicle of wasted time

I see descriptions of the fairest wights,

And beauty making beautiful old rhyme

In praise of ladies dead and lovely knights,

Retratos me depara a história primorosos

De mulheres que, antanho, exornaram o mundo.

A elas, como a gentis cavaleiros famosos, Honraram versos que, inda, a alma nos tocam fundo.

O tradutor se utiliza de inversões sintáticas e vocábulos incomuns no soneto 106 como: "Retratos me depara a história primorosos de mulheres que, antanho, exornaram o mundo" (v. 1-2); "apanágios opimos" (v. 8); "Mas, posto vos previsse o olhar vaticinante," (v. 11). Ou mesmo no soneto 107: "estringir" (v. 3); "metuendo" (v. 5); "áugure" (v. 6); e a estrutura, "A Morte, ei-la impotente" (v. 10). Logo, observa-se que o leitor, seja experiente ou não, certamente precisará recorrer a um dicionário a fim de obter a definição de tais palavras.

O contexto literário em que se insere a publicação de 1956 é ainda 0 neoparnasianismo da geração de 45 , que buscava um rigor quanto às formas fixas e a estética formal da poesia, como já mencionado. Seguindo essa ideia, vale especular que a motivação por um léxico mais arcaizante pode ter sido 
firmada na ideia de corresponder com a linguagem da Inglaterra do século XVII, apesar de a hipótese não ser confirmada a partir da leitura dos paratextos.

\section{Flora Machman (1921-2002)}

De acordo com breve biografia disposta em seu livro de crônicas Chuva Miúda (2011), Flora Machman foi a primeira recifense a receber o registro de jornalista em Recife e uma das primeiras advogadas do Brasil, sem jamais, no entanto, ter desempenhado a profissão. Foi amiga das escritoras Clarice Lispector e Cecília Meireles, e escreveu e publicou diversas crônicas na coluna do jornal Folha da Manhã, de Recife, a partir de 1947. Foi diretora do Museu do Índio em 1971 e tradutora de contos e de poesia.

Entre os contos dos escritores que traduziu, é possível citar os do ucraniano Scholem Aleichem, do israelence Chaim Nachman Bialik e do indiano Rabindranath Tagore. Flora Machman também traduziu um dos sonetos de Shakespeare, o de número 27, publicado em 1964 na edição comemorativa do quarto centenário do nascimento de Shakespeare (MELLO; MONAT, 1964, p. 61), juntamente com o original em inglês. A tradução foi feita "quase toda em decassílabos" (GUEIROS, 2015, p. 152), no esquema rímico abba abba cdc eed, diferente do inglês, disposto na forma abab cdcd efe $\mathrm{fgg}^{38}$. Logo, a tradutora opta por um esquema de versificação mais comum na língua portuguesa, de dois quartetos e dois tercetos, o que demonstra traços de um rigor formal, que nesse caso não se aproxima do momento literário em que se inseria. Observe-se a primeira quadra do soneto 27 em inglês, seguida da tradução de Machmann:

\section{Sonnet 27}

Weary with toil, I haste me to my bed,

The dear repose for limbs with travel tired,

But then begins a journey in my head

\footnotetext{
${ }^{38}$ Vale frisar que a disposição das partes do soneto na página não segue o formato inglês, com um bloco de 12 versos seguido de um dístico com recuo de parágrafo. Na publicação do IV Centenário, tanto o soneto em inglês quanto o em português são apresentados na forma de duas quadras e dois tercetos.
} 
To work my mind, when body's work's expired.

Exausto da luta, atiro-me ao leito,

Caro repouso das pernas fatigadas;

E a mente não descansa das jornadas

Ativas, quando o lasso corpo deito.

Sua tradução do soneto 27 se insere na época da poesia concretista que se inicia por volta de 1958, com Décio Pignatari e os irmãos Augusto e Haroldo de Campos (BRITTO, 2013). Esse movimento tinha obviamente uma ideologia estética oposta à geração antecedente, isto é, poetas desse período procuravam não se restringir aos aspectos formais fixados, abolindo assim, o metro, a rima e o verso como elementos que constituem a linguagem poética, como bem aponta Paulo Britto (2013). Nesse sentido, o poema se torna uma forma de arte visual (CAMPOS et al.,1975). Contudo, pode-se observar que Machman busca rimar em sua tradução e opta pelos decassílabos, logo, há um distanciamento quanto ao estilo predominante da época.

\section{Geir Campos (1924-1999)}

Segundo consta no Dicionário de Tradutores Literários no Brasil, ou DITRA (CARDELLINO; COSTA, 2005), Geir Campos era capixaba e estudou Direito, Engenharia Civil e pilotagem naval na Escola da Marinha, onde mais tarde veio atuar como piloto. Foi mestre e doutor em comunicação pela Universidade Federal do Rio de Janeiro (UFRJ), atuou na SBAT (Sociedade Brasileira de Autores Teatrais) e na ABRATES (Associação Brasileira de Tradutores), da qual foi o primeiro presidente e, além disso, foi filiado ao PSB (Partido Socialista Brasileiro). De formação eclética, assim também foi sua carreira profissional, pois exerceu o ofício de professor, na categoria fundamental e universitária, editor, contista, radialista, tradutor e poeta.

Atuou com grande intensidade no campo da poesia e da tradução. Escreveu diversas obras de poesia e também organizou antologias que 
cobriam desde os poetas contemporâneos a poemas e poetas eróticos, desde tratados sobre a profissão do poeta a obras que mapeavam e analisavam os poetas atuantes do século XX ou os poetas do Rio de Janeiro. Ao todo, registram-se 15 obras de poesia, 15 de teatro, dois livros de literatura infantojuvenil, diversos ensaios e artigos em revistas científicas. O amplo currículo do poeta ainda abrange obras de referências no campo da literatura e da tradução, como Tradução e ruído na comunicação teatral (1982), O que é tradução (1986) e Como fazer tradução (1986). Além disso, tinha aptidão em diversos idiomas, tais como o francês, inglês, alemão, italiano, espanhol, russo e grego.

Em 1964, publicou duas traduções dos sonetos de Shakespeare, de número 25 e 116, na mesma edição comemorativa dos 400 anos do nascimento de Shakespeare, organizada por Barbosa Mello e Olympio Monat, em que se encontra o soneto traduzido por Flora Machmann. Só que, diferentemente do que ocorre com Machmann, os dois sonetos não vêm acompanhados do original inglês, e sua disposição na página é a tradicional, com um bloco de 12 versos arrematado pelo dístico com recuo de parágrafo. Embora sua publicação se insira no momento concretista, que buscou distanciar-se do rigor das formas fixas na poesia, a tradução dos sonetos de Shakespeare por Geir Campos segue uma correspondência com os aspectos formais do poeta inglês, pois o tradutor opta pelos versos decassílabos e o esquema rímico do original em inglês, abab cdcd efef gg, como se pode observar na primeira quadra do soneto 116 :

\section{Sonnet 116}

Let me not to the marrige of true minds

Admit impediments: love is not love

Which alters when it alteration finds,

Or bends with the remover to remove. 
Possa eu negar obstáculos à aliança

dos corações sinceros, pois não é

amor êsse que muda ao ver mudança

ou, curvado à inconstância, perde a fé.

Vale mencionar que Gueiros (2015) aponta que o tradutor foi um "esplêndido poeta e mestre da poética" (p. 152). Além de suas duas traduções dos sonetos de Shakespeare, Geir Campos traduziu a obra Macbeth e a publicou em 1970, pela editora Civilização Brasileira.

\section{Oscar Mendes (1902-1983)}

O pernambucano Oscar Mendes nasceu em Recife e com 24 anos mudou-se para Minas Gerais, onde exerceu o cargo de promotor de justiça e juiz municipal. Transferiu-se para Brasília em 1966, ingressando na Academia Mineira de Letras e na Associação Nacional de Escritores. Foi professor universitário, tradutor, conferencista e crítico literário, de acordo com a Associação Nacional de Escritores (ANE). Foi responsável, junto com Fernando Carlos de Almeida Cunha Medeiros, por uma tradução do teatro completo de Shakespeare publicada em 1969 pela editora José Aguilar em três volumes: tragédias (vol. I), comédias (vol. 2) e dramas históricos e obras líricas (vol. 3). Conforme informado na edição, Mendes foi responsável pela revisão das peças, pelas traduções das canções na poesia dramática e pela tradução de toda a obra lírica, que contempla os poemas narrativos e os sonetos.

$\mathrm{Na}$ tradução dos sonetos, Mendes (1969) opta por utilizar versos de doze sílabas, que asseguram uma maior possibilidade de palavras polissilábicas e também auxiliam na preservação das imagens e dos "conceitos" de Shakespeare, como argumenta o tradutor na sua nota introdutória sobre as obras líricas (1969). Nesse paratexto, Mendes afirma que precisa explicar aos leitores porque não seguiu a métrica shakespeariana, que 
se traduz comumente sob forma de decassílabos, e optou por não rimar os versos. Em suas palavras,

dada a diferença enorme entre a língua portuguêsa e a inglêsa, em que preponderam as palavras monossilábicas, impossível seria, sem sacrifício das idéias, das imagens, dos conceitos, manter a mesma métrica shakespeariana. Preferi, pois, utilizar-me do verso alexandrino clássico, por ser mais amplo e possibilitar assim maior número de palavras polissilábicas. (MENDES, 1969, p. 737)

Nota-se, portanto, que Mendes privilegia o sentido em detrimento da forma, assim como Silva Ramos, que também optou pelos dodecassílabos para "não sacrificar muita coisa do texto" (RAMOS, 2008, p. 12), como já mencionado.

Quanto às rimas, diz Mendes:

Não procurei tampouco rimar. Sendo a rima essencialmente música e diversa a música de cada língua, optei pelo sacrifício dessa música em favor da idéia de cada verso, pois a procura da rima levaria a modificações, muitas vezes desfiguradoras do pensamento do poeta e das imagens e metáforas que empregou. (1969, p. 737)

Novamente o motivo para a discordância em relação ao original é a preocupação, nas palavras do tradutor, em "ser fiel, na medida da minha compreensão, ao pensamento do autor" (MENDES, 1969, p. 737)

Isto posto, segue um trecho do soneto 18 no original e da tradução de Mendes:

\section{Sonnet 18}

Shall I compare thee to a summer's day?

Thou art more lovely and more temperate:

Rough winds do shake the darling buds of May,

And summer's lease hath all too short a date:

Posso te comparar a um belo dia estivo?

Bem mais suave e amena é a tua natureza;

Crestam ventos brutais de maio ou tenros brotos

E o baile do verão tem curta duração.

No que concerne ao contexto literário do volume traduzido, vale dizer que é o momento em que a poesia marginal ganha relevo no Brasil. Poetas adeptos desse movimento buscavam métodos pouco convencionais para a 
divulgação de suas obras, uma vez que a ditadura instaurada no Brasil (19641985) restringia muito da literatura divulgada. Segundo Neto (2018), esse fenômeno literário conhecido como poesia marginal ou "geração mimeógrafo" foi influenciado pelo Tropicalismo, bem como por outros movimentos de contracultura; portanto, uma das características desses poemas é a promoção de críticas a todos os meios convencionais e já consagrados no âmbito cultural e literário. A escrita produzida pelos adeptos da poesia marginal era repleta de coloquialidade e de humor, de modo a aproximar o leitor ao texto, mesmo aqueles sem muita fluência na leitura de poesia. Havia um enfoque maior na subjetividade e uma oposição quanto à preponderância dos elementos formais na poesia, bem como de outros movimentos que valorizavam tais aspectos (BRITTO, 2013). Além disso, um dos temas mais preponderantes na poesia da época era a "sobrevivência" ao chamados "anos de chumbo" entre 1968 e 1975 (ibid.). Pode-se dizer, portanto, que o tratamento que Mendes (1969) deu aos sonetos não reflete a tendência dominante da poesia brasileira, já que suas traduções adotam uma forma poética fixa, embora sejam um pouco subversoras no que diz respeito ao esquema rímico.

\section{Guilherme Figueiredo (1915-1997)}

Guilherme de Oliveira Figueiredo, nascido em Campinas, foi escritor, professor, dramaturgo e tradutor. Iniciou sua carreira se graduando em Direito, e após a conclusão de seu bacharelado, tornou-se crítico teatral, estreando mais tarde como dramaturgo brasileiro. Foi tradutor de inúmeros autores teatrais, como Molière, George Bernard Shaw e William Shakespeare, entre outros, segundo Pereira et al. (2019). Não teve uma formação profissional na área de tradução, nem se uniu a movimentos literários de sua época. Em relação a Shakespeare, traduziu 7 dos 154 sonetos $(22,23,55,66,71,91$ e 130), dos quais foram publicados no Rio de Janeiro, no Jornal de Letras, em 1971, os números 22, 23 e 71 e, em 1973, pela Edição Cátedra, os outros quatro $(55,66,91,130)$. Segue a primeira quadra do soneto 55 em inglês, seguida da tradução de Figueiredo: 


\section{Sonnet 55}

Not marble, nor the gilded monuments

Of princes, shall outlive this powerful rhyme;

But you shall shine more bright in these contents

Than unswept stone, besmeared with sluttish time.

Nem mármore ou dourados monumentos

De reis viverão mais do que estas rimas:

Brilharás nestes lúcidos acentos

Além da suja pedra onde te encimas.

Quanto aos aspectos formais e semânticos, Figueiredo opta pelos decassílabos, e Gueiros comenta que são "[...] parafraseados numa aproximação magnífica" (2015 p. 152). Tal afirmação corrobora a escolha do tradutor por preservar o esquema de rimas cruzadas com um dístico final, como no original.

Embora não haja registros de que Guilherme de Figueiredo tenha se identificado com algum movimento literário de sua época, durante a publicação da tradução dos sonetos shakespearianos o contexto literário predominante ainda era o momento da poesia marginal, uma vez que esse movimento ocorre em resposta ao regime militar, que se estendeu até o ano de 1985. Como já salientado, havia a convivência da pluralidade de estilos na poesia, o que desconstruía a ideia de um estilo poético principal, e a divulgação se dava, sobretudo, por meios não convencionais. Todavia, Figueiredo publica os sonetos traduzidos pelo Jornal de Letras e opta pela correspondência aos aspectos formais do soneto de Shakespeare.

\section{Ivo Barroso}

Tradutor, diplomata, poeta e escritor, Ivo do Nascimento Barroso nasceu em 1929. Sua predileção por traduzir poesia começou desde cedo, 
unindo-se mais tarde ao movimento literário concretista. A poesia de caráter concretista tinha como ideia primordial o uso dos recursos gráficos que as palavras dispõem sem quaisquer preocupações com a estética tradicional, que apresenta uma estrofação de apreensão mais imediata. Nesse sentido, o poema concreto busca um apelo visual, sendo esse um dos motivos que seus proponentes o chamam de poema-objeto (CAMPOS et al., 1975).

$\mathrm{Na}$ época em que começou a traduzir os sonetos de Shakespeare (1968-70), Ivo Barroso residia na Holanda, onde, pela primeira vez, Ihe foi apresentado um variorum de sonetos do poeta inglês. Daí iniciou-se sua empreitada. Trouxe desse país 24 sonetos traduzidos $(1,2,12,14,15,17,18$, 19, 22, 23, 27, 28, 29, 30, 55, 65, 71, 73, 98, 106, 116, 127, 138 e 144), os quais foram revisados e editados pela editora Nova Fronteira em 1973 e publicados em formato "coffee-table book (30 x 40cm)" (BARROSO, 2015, p. 4), bilíngue e com ilustrações. Na avaliação de Alfredo Bosi (2015, p. 254), os sonetos de Ivo Barroso foram "esplendidamente transpostos para um vernáculo enxuto e de corte clássico". Em sua nota introdutória disposta na $5^{\mathrm{a}}$ edição de 2015 , o tradutor explicita que a $2^{2}$ edição da obra traduzida data de 1975, e em um modelo mais comercial publicado pela mesma editora, são reproduzidos os sonetos já traduzidos anteriormente, mas sem o acréscimo de ilustrações.

No que concerne à $3^{a}$ edição (1991), publicada também pela Nova Fronteira, Barroso assinala que houve a inserção de mais seis sonetos traduzidos, perfazendo um total de 30. Além disso, o prefácio de Antônio Houaiss deslocou-se para o final, transformando-se, assim, em um posfácio. Já na $4^{a}$ edição em 2005, a obra traduzida com 42 sonetos e em formato de bolso sofreu também algumas alterações, como a inserção de mais 11 sonetos, sendo o de número 91 revisado e inserido em uma nova versão. 0 posfácio de Antônio Houaiss retomou à posição original de prefácio, deslocando-se para o final o estudo minucioso de Nehemias Gueiros. Vale mencionar que Ivo Barroso (2015) não deixa claro em suas notas se as edições $2^{a}, 3^{\underline{a}}$ e $4^{\underline{a}}$ eram bilíngues; há apenas a evidência de que a primeira e 
última edição seguiram tal formato. $\mathrm{Na} 5^{\circ}$ edição, que o tradutor faz questão de intitular como definitiva, a coleção de 50 anos da editora traz 50 sonetos publicados pela Nova Fronteira, e o tradutor destaca que o objetivo primeiro de seu trabalho foi lograr contribuir com a tradução de um terço do volume dos 154 sonetos de Shakespeare (BARROSO, 2015)

No que tange ao aspecto formal, o trabalho de Barroso é feito em decassílabos e busca uma tradução mais sucinta, sem deixar de observar o ritmo do original inglês. No entanto, o tradutor reconhece que o dodecassílabo é o caminho mais imediato para solucionar os problemas que a língua inglesa, com elevado percentual de palavras monossilábicas, traz para os tradutores de sonetos. Observe-se a primeira quadra do soneto 30 no original, seguida da tradução de Barroso:

\begin{abstract}
Sonnet 30
When to the sessions of sweet silent thought

I summon up remembrance of things past, I sigh the lack of many a thing I sought, And with old woes new wail my dear time's waste:
\end{abstract}

Quando às sessões do mudo pensamento Convoco as remembranças do passado, Sentindo a ausência do que amei, lamento Com velhos ais, de novo, o tempo amado;

De acordo com o prefácio e o pósfacio encontrados do volume dos 50 Sonetos - William Shakespeare de Barroso (2015), os autores dos paratextos defendem a ideia de que o tradutor busca estabelecer uma estrita correspondência linguística e imagética com o original, mesmo sabendo que uma tradução absoluta seria impossível. É o que afirma Antônio Houaiss, autor do prefácio mencionado, esclarecendo que a visão sobre tradução de Barroso está embasada na ideia de recriação e, não, de uma mera tradução mecânica. 
Essa perspectiva também é encontrada em Silva Ramos (2008), ao afirmar que uma tradução implica forçosamente um ato de recriação. Por fim, o esquema de rimas adotado por Barroso segue o padrão do original, abab cdcd efef $g g$, propondo assim uma tradução que se aproxime do original quanto aos elementos formais do soneto inglês.

Embora sua formação como tradutor tenha sido ligada ao movimento concretista, que trata o poema como poema-objeto e desconsidera qualquer submissão aos elementos formais, nota-se em uma breve análise que, no que concerne à tradução dos sonetos shakespearianos, o tradutor buscou observar o contrato métrico e o esquema de rimas estabelecido no original, somados a uma linguagem mais formal.

\section{Jorge Wanderley (1938-1999)}

Nascido em Pernambuco, Jorge Wanderley foi poeta, tradutor, médico e professor na Universidade Federal Fluminense. Começou a escrever muito cedo, e, aos 16 anos de idade, publicou seu primeiro livro, Gesta e outros poemas, em 1960. Embora tenha se graduado em medicina, abandonou a carreira ao chegar ao Rio de Janeiro, onde concluiu seu mestrado e doutorado em Letras pela PUC-Rio, com pesquisas pioneiras sobre a tradução de poesia. É autor de uma obra poética, pela qual é considerado nome de referência, de acordo com o dicionário de tradutores da UFSC (Universidade Federal de Santa Catarina) em seu repositório on-line.

Jorge Wanderley, com auxílio da bolsa que recebeu pela Fundação Vitae para fazer traduções, aventurou-se na complexa tarefa de traduzir integralmente os 154 sonetos de Shakespeare, e sua primeira edição data de 1990, pela editora Civilização Brasileira, e a segunda, de 1991, pela mesma editora, ambas as edições em formato bilíngue. Em sua introdução, o tradutor e poeta tece comentários relevantes sobre o ato de traduzir. Segundo ele, "toda tradução é um ato de força, embora seu sucesso seja o de parecer negálo. De tal modo que seu músculo não transpareça na leveza da dança" (1991, p. 18-19). Sendo assim, julga que uma tradução em decassílabos deve 
necessariamente expressar a fluidez e dar "leveza a essa dança", ou seja, a musicalidade, um dos elementos mais importantes no processo tradutório, mais relevante inclusive "do que as perdas que tiver sofrido na negociação" (p.20). Wanderley aborda assim, a questão bastante discutida entre os tradutores e estudiosos da tradução acerca do processo de perdas e compensações em que o profissional necessita reconhecer quais elementos são mais relevantes durante o processo tradutório. Diferentemente de alguns tradutores, Wanderley argumenta claramente sobre sua preferência pela forma em detrimento ao material semântico. Como já visto, para Silva Ramos e Oscar Mendes é quase impossível manter uma correspondência estrita quanto ao metro e à rima, pois, para eles, o tradutor deve sobretudo buscar correspondência com o sentido. Alguns tradutores, tais como Thereza Christina Rocque da Motta (2006), Jorge Furtado e Liziane Kugland (2010) e Oscar Dourado (2017), atestam que nem mesmo Shakespeare buscou uma estrita observância dos aspectos formais e, por vezes, subverteu a forma do soneto inglês; Wanderley, por outro lado, ratifica que "a musicalidade de um verso traduzido sempre falará mais alto [...]" (p. 20).

Wanderley também comenta na introdução que os sonetos de Shakespeare são especialmente uma classe de versos de circunstância, e sustenta essa ideia nas duas primeiras páginas de abertura. Os "Dutysonnets" (p. 9), como expõe, referem-se a poemas escritos cuja tarefa era agradar ao seu "grão-senhor" (ibid.), isto é, ao patrono, manifestando relação de amizade, afeição, plena dedicação ao serviço etc. Sendo assim, essas formas poéticas estão imbricadas em um contexto circunstancial que precisa ser levado em consideração para que se possa compreender e identificar o soneto no tempo e no espaço. De igual maneira, Harold Bloom (2008), em vários momentos da sua obra, alude às circunstâncias da vida de Shakespeare e ao contexto histórico e sociocultural durante a composição de seus sonetos para analisar as figuras evocadas nos poemas como, por exemplo, a identidade da Dark Lady, do Fair Youth etc. Contudo, Jorge Wanderley (1991) afirma que Shakespeare, por sua expressividade com as palavras, transcende 
esse aspecto circunstancial dos sonetos, que "se destacam do contexto para luzir num céu exclusivo, onde esplendem insuperáveis consumando esta que é a instância maior do literário, a transcendência [...] ainda que tenha partido da realidade ou da fantasia..." (p.10). No entanto, ressalta que o contexto nos sonetos é um elemento necessário para o entendimento do poema e que, sobretudo em Shakespeare, a leitura de um único soneto ou de um pequeno grupo sem levar em conta esse aspecto resultará no insucesso de se ter uma ideia, mesmo que parcial, da força de expressão do Bardo.

No que se refere aos elementos formais, o tradutor segue o esquema de metrificação correspondente ao padrão do original, isto é, o decassílabo como correspondente mais próximo do pentâmetro iâmbico inglês, justificando que o soneto shakespeariano é "um ser [...] basicamente musical" (1991, p. 19). Mas salienta a questão da síntese da língua inglesa em relação ao português e, nesse jogo de negociações, opta pela compactação do material semântico em detrimento dos elementos formais, pois para ele "uma tradução deve fluir" (p. 20). O aspecto rímico é observado com rigor, mantendo-se em doze rimas cruzadas e duas parelhas, o dístico final, abab cdcd efef gg. Em suas traduções se veem ocorrências de notas de rodapé explicativas quanto ao léxico e de soluções tradutórias, bem como de aporte teórico para explicitar suas tais decisões. Veja-se, por exemplo, a primeira quadra do soneto $24 \mathrm{em}$ original, seguida da tradução de Wanderley:

\section{Sonnet 24}

Mine eye hath played the painter and hath stelled

Thy beauty's form in table of my heart;

My body is the frame wherein 'tis held,

And perspective it is best painter's art.

Fazendo-se pintor, pintou meu olho

De tua graça a tela no meu peito;

Meu corpo é a moldura em que a recolho

E em perspectiva o artista foi perfeito. 
Vale salientar, ainda, um dado a respeito das traduções dos sonetos shakespearianos realizadas por Wanderley. Há um registro recente de uma nova publicação de seus sonetos traduzidos, com data de 2019. A iniciativa foi de Ivan Pinheiro Machado, que os republicou pela editora L\&PM, seguindo o mesmo formato bilíngue das publicações anteriores de 1990/91 pela Civilização Brasileira.

O contexto literário em que o volume traduzido se insere é do pósmodernismo, que se estende até o momento atual. Sendo assim, vale relembrar ao leitor que algumas considerações acerca desse momento foram feitas no início deste capítulo. Entretanto, ainda se faz necessário traçar alguns comentários a respeito da década de 1990.

Hollanda (1998) aponta que os poetas de 1990 estão atrelados a uma conjuntura de mudanças no mercado cultural que busca ir de encontro a uma sociedade massificada e que, diferentemente dos ligados à "geração mimeógrafo", esses poetas têm formação superior e acesso aos meios mais convencionais, podendo atuar também em áreas que viabilizam o acesso à comunicação, como o jornalismo e a academia. Além desse fato, a produção poética é marcada pelo hibridismo de estilos e pluralidade de vozes, traço mais marcante desse momento, ou como assevera: "um emaranhado de formas e temáticas sem estilos ou referências definidas" (p. 11). Talvez seja essa uma das dificuldades em se caracterizar o momento do pós-modernismo, dado o paradoxo evidente que contrapõe, de um lado, um momento em que se promove uma pluralidade de vozes "preocupada[s] em encontrar a sua própria voz" (p. 17), com a conjuntura apontando para um cenário de normalidade, e de outro, as décadas marcadas por revoluções, desde o modernismo à tropicália (BRITTO, 2013). Sejam quais forem as perspectivas, registre-se o que diz Capela (2006) acerca do momento: "lembra o espírito marginal dos anos 1970" (p. 197), mas é claro que com mais liberdade e acesso aos meios de comunicação. 


\section{Barbara Heliodora (1923-2015)}

A carioca Heliodora Carneiro de Mendonça atuou como professora, tradutora, pesquisadora, escritora, ensaísta, diretora e crítica de teatro. Tornou-se referência nos estudos sobre Shakespeare, e suas investigações muito contribuíram para os estudos desse poeta inglês no Brasil. Heliodora fez bacharelado em Língua e Literatura Inglesas no Connecticut College (EUA) e doutorou-se em Artes pela Universidade de São Paulo (USP). Durante a faculdade, especializou-se em inglês - aprendido na infância - aprimorando-o por meio das peças de Shakespeare que traduziu. Já como professora, deu continuidade ao ofício de tradução, iniciado por sua mãe, Anna Amélia de Queiroz Carneiro de Mendonça, buscando preservar a forma original de verso e prosa das peças traduzidas (AGNES; GUERINI, 2008). Além disso, em 1958, atuou como atriz e também escreveu e dirigiu o roteiro Um Homem Chamado Shakespeare. Contudo, foi na crítica teatral que se tornou renomada, realizando conferências sobre as peças shakespearianas, bem como publicando suas críticas em veículos impressos como Tribuna da Imprensa de Carlos Lacerda, Jornal do Brasil, no Suplemento Dominical, e Jornal O Globo (AGNES; GUERINI, 2008). Sendo assim, é evidente que Barbara Heliodora tem formação mais como especialista em teatro do que como poeta, como é o caso da maioria tradutores aqui dispostos.

A tradução e organização de trechos das peças e de 16 dos 19 sonetos shakespearianos traduzidos foram realizadas em conjunto com sua mãe, Anna Amelia, que traduziu três sonetos no volume publicado em 2000, pela editora Ediouro. Como expresso no título da obra, Poemas de amor - William Shakespeare, as traduções enfocam a temática do amor, contudo, vale frisar que, na introdução aos sonetos, Barbara Heliodora menciona que Shakespeare não concebia o amor unicamente entre dois seres apaixonados, mas como um sentimento de "aplicação muito ampla" (HELIODORA, 2000, p.11). Segundo ela, o poeta inglês aborda o amor romântico entre marido e mulher, o amor de pais e filhos e até mesmo o amor à paz e à pátria; sendo assim, a proposta do volume traduzido é evidentemente reunir fragmentos que 
manifestem a intensidade desse sentimento tão tematizado pelo Bardo. Seja no gênero lírico ou dramático, o leitor consegue ter acesso a duas dimensões da escrita shakespeariana acerca de um mesmo tema. Barbara Heliodora se incumbe da tarefa de diferenciar a forma poética soneto do texto dramático, compreendendo, portanto, que o soneto tem como proposta ser uma leitura mais subjetiva feita pelo indivíduo em "seu colóquio particular com o texto escrito" (p.14), que the possibilitará constantes releituras e, assim, uma reflexão mais densa sobre a ideia apresentada. Já o texto dramático tem como abrangência o grande público, que se entretém pela compreensão mais imediata do texto dramatúrgico, uma vez que "a ação não pode esperar até que o espectador compreenda melhor o que foi dito" (p. 14-15). Cabe mencionar aqui que Jorge Wanderley (1991) atesta que "a leitura isolada de um soneto ou de um grupo deles jamais dará a ideia real e plena da força desses poemas" (p. 11), levando a entender que o conhecimento do contexto no qual Os Sonetos se inserem é fundamental na compreensão dessa escrita poética.

No que tange aos elementos formais, o contrato métrico e o esquema de rimas empreendidos nas traduções seguem a forma do original, abab cdcd efef $g g$, sendo produzidos em decassílabos utilizados como um correspondente do pentâmetro iâmbico. A título de ilustração, reproduzimos primeira quadra do soneto 130 no original, seguida da tradução de Heliodora:

\section{Sonnet 130}

My mistress' eyes are nothing like the sun;

Coral is far more red than her lips' red;

If snow be white, why then her brests are dun;

If hairs be wires, black wires grow on her head.

Não tem olhos solares meu amor;

Mais rubro que seus lábios é o coral;

Se neve é branca, é escura a sua cor;

E a cabeleira ao arame é igual. 
Barbara Heliodora menciona, contudo, que a forma shakespeariana para produção de sonetos se difere da camoniana e, inclusive, da petrarquiana, já que os sonetos de Petrarca são organizados por duas quadras, em geral abba, seguidas de dois tercetos de variação rímica bem diversa, como já explanado no início deste trabalho. Heliodora ainda reforça que Shakespeare tinha consciência tanto do modelo concebido na Inglaterra, que já vinha sido desenvolvido por seus predecessores, Wyatt, Surrey, Sidney e outros, como da forma europeia, pois em Trabalhos de amor perdidos, o personagem francês Berowne produz um soneto segundo o padrão europeu, isto é, versos de 12 sílabas estruturados por duas quadras e dois tercetos de rimas alternadas. Por fim, a tradutora e crítica teatral atesta também que, por conta do vocabulário monossilábico da língua inglesa, é possível a supressão de algumas imagens quando vertidas para o vernáculo, salientando a dificuldade de transpor para o idioma as mesmas ideias da língua de partida, como se observa em uma entrevista concedida e disponibilizada on-line pelo site Shakespeare Brasil, da UFPR (2007).

Quanto às estratégias tradutórias, Barbara Heliodora busca manter "[...] a elaboração formal dos sonetos (tanto nas ideias quanto nos recursos usados para expressá-las [...]" (2010, p. 14), embora reconheça a dificuldade de correspondência lexical entre 0 original e a tradução, devido às particularidades de cada língua, como mencionado no parágrafo anterior. Além disso, não há evidências, no volume traduzido, de notas de rodapé ou explicações para as soluções tradutórias dos elementos semânticos.

O contexto literário no qual se insere a publicação da tradução dos poemas de amor era também o momento do pós-modernismo. Como se discutiu sobre o tradutor anterior, esse cenário tem como uma de suas características a pluralidade de estilos e formas. Sendo assim, nesse momento de normalidade (BRITTO, 2013) não há restrição de temas, como se poderia esperar de um regime militar na época da poesia marginal. Todavia, Heliodora se exime de comentar a respeito das referências ao desejo erótico ou carnal 
nos sonetos shakespearianos, como, por exemplo, as relações hetero e homoafetivas, como bem fazem os tradutores Oscar Dourado (2017) e Elvio Funck (2019) - cujas traduções são mais recentes - quanto ao erotismo dos sonetos. Outro aspecto que é importante notar é o cenário da poesia que vem se tornando mais visível nestes últimos anos, principalmente, a partir do novo milênio. Britto (2013) comenta que "os poetas já não integram seitas literárias que se excomungam mutualmente" (p. 11) e que esses "[...] mais jovens sentem-se livres para lançar mão dos repertórios técnicos deste ou daquele movimento histórico[.]" (ibid.); é o que houve com o volume em questão, pois tanto Barbara Heliodora quanto sua mãe, Anna Amélia, optaram por preservar a forma original do verso, em um momento literário que não exigia rigor formal.

\section{Renata Maria Parreira Cordeiro}

Segundo o seu Currículo Lattes, Renata Cordeiro, conforme assina em suas publicações, é uma acadêmica ativa, com diversos trabalhos publicados, dentre eles, as suas traduções dos sonetos de Shakespeare nos diversos volumes do Caderno de Literatura em Tradução da Universidade de São Paulo (USP). Tem graduação em Filosofia e Especialização em Tradução-Francês, ambas pela USP, e é tradutora pública e intérprete comercial da língua francesa.

Em 2003, publicou pela editora Landy um volume com traduções dos sonetos de Shakespeare contendo 17 sonetos traduzidos (do 1 ao 17) sob o título de Sonetos ao Jovem Desconhecido. Além disso, observa-se no volume que os sonetos traduzidos são seguidos de uma seção intitulada $A B C$ dos Sonetos - que é uma coletânea de citações das obras dramáticas e líricas do Bardo, com o objetivo de enriquecer a leitura dos poemas traduzidos, conforme explicitado na nota de número 69. Após a seção, há a tradução de um fragmento da peça Romeu e Julieta, a cena dois do segundo ato, no Jardim dos Capuletos, em que ocorre um diálogo entre os dois enamorados sob a janela dos aposentos de Julieta. Por fim, há uma breve cronologia da vida e obra de Shakespeare, bem como de acontecimentos durante a Inglaterra do 
século XVI e XVII, que incluem, por exemplo, a grande peste em Londres em 1591; a criação da tragédia Macbeth em 1606; e até mesmo o assassinato do rei Henrique IV, na França. Vale comentar que a própria tradutora ressalta que, evidentemente, algumas datas não são tão exatas.

Em sua breve introdução de duas páginas e meia, a tradutora afirma que escolher os primeiros 17 sonetos certamente levaria às seguintes indagações: "Por que os 17 primeiros?" e "Quem teria sido esse "jovem desconhecido'?" (p. 11). Ela explica que os sonetos selecionados são aqueles que fazem referência à juventude, explorando todo o seu esplendor, vivacidade e "desfrute da beleza" (ibid.). Busca ainda pontuar que Shakespeare vai além dessa perspectiva, pois, como se vê do primeiro ao décimo sétimo soneto, a temática é abordada sob a ótica da perenidade da beleza, na qual a juventude deve constantemente dar frutos sendo produtiva, ou melhor, reprodutiva, isto é, a procriação é o caminho de perpetuação do vigor e da beleza alcançados na juventude, como assinala. Essa perspectiva parece aproximar-se do sentido de transcendência comentando por Wanderley (1991, p. 10), quando o tradutor exemplifica que

"[...] muitos dos poemas resultantes dessa série, escrita entre 1592
e 1593-4 ultrapassam sua condição de origem - o circunstancial -e
se destacam do contexto para luzir num céu exclusivo, onde
esplendem insuperáveis consumando esta que é a instância maior
do literário, a transcendência, a universalidade alcançada a pleno,
ainda que tenha partido da realidade ou da fantasia mais
comezinhas

Além desse aspecto, Renata Cordeiro descreve e contrapõe algumas hipóteses de identificação do jovem desconhecido, como por exemplo, a de A. L. Rowse, em 1964, de que o jovem aludido na obra shakespeariana seria Henry Wriothesley. Outra tese ainda apresentada pela tradutora e que confronta a de Rowse é a de John Dover Wilson, de 1966, que assevera que o rapaz a quem a obra é dedicada seria William Herbert, o conde de Pembroke. Além disso, a tradutora considera que outros candidatos a Mr.W.H. poderiam ser William Hervey, padrasto do conde Southampton; William Hathaway, cunhado de Shakespeare; ou mesmo William Hall, caso houvesse a supressão do terceiro ponto em "Mr. W. H. ALL". Todos esses candidatos seriam válidos 
se 0 termo begetter, presente na dedicatória, tivesse um significado equivalente a procurador. Embora Cordeiro apresente tais hipóteses, não demonstra em qual delas está mais inclinada a acreditar, e ao final de sua introdução, questiona a real necessidade de conhecer tal identidade, colocando em evidência o desfrute e o prazer da leitura pelo simples ato de ler e de contemplar a beleza poética dos sonetos.

Sobre as noções e estratégias tradutórias que regem a sua prática, não há nenhuma explanação expressa na sua introdução ou nas notas explicativas, mas pode-se observar que a tradutora adota uma versificação dodecassilábica, com as rimas alternadas e o dístico de rimas emparelhadas, portanto, abab cdcd efef gg. Verifica-se, nesse caso, o soneto 11 no original, acompanhado da tradução de Renata Cordeiro:

\section{Sonnet 11}

As far as thou shalt wane, so fast thou grow'st In one of thine, from that which thou departest; And that fresh blood which youngly thou bestow'st Thou mayst call thine when thou from youth convertest:

Depressa crescerás, apressado minguante, Num filho teu, de quem, por fim, te apartarás;

E quanto sangue tu lhe outorgues, sendo infante, Quando velho, dizê-lo teu, tu poderás:

As notas se encontram em uma seção posterior aos poemas e ao trecho dramático traduzidos, mas há, em sua maioria, explicações sobre as escolhas lexicais e contextuais dos sonetos e da cena de Romeu e Julieta. No $A B C$ dos Sonetos, há citações de temas recorrentemente explorados pelo autor tanto em seu cânone teatral quanto lírico. Além disso, os sonetos traduzidos estão em formato bilíngue, proporcionando a leitura na língua de partida e de 
chegada; já o trecho dramático é apresentado somente no vernáculo da tradutora.

O momento literário da publicação do volume traduzido por Renata Cordeiro é, evidentemente, o pós-modernismo, em que não há fortes traços formais hegemônicos no campo da poesia; há, todavia, como já dito, a pluralidade de formas que convergem entre si, cabendo esse ou aquele tradutor usar os recursos disponíveis de acordo com a sua proposta de tradução.

\section{Milton Felipe de Albuquerque Lins (1927-2015)}

Para obter dados biográficos deste tradutor foi necessário recorrer ao jornal Diário de Pernambuco em seu domínio on-line, fonte bastante confiável por se tratar do jornal mais antigo em circulação da América Latina, como atesta o próprio site. A publicação da matéria no Diário de Pernambuco, datada de março de 2015, em que notifica o falecimento do tradutor, conta com vários dados acerca de sua vida e carreira. Milton Lins, como era mais conhecido, foi acadêmico formado em medicina, ocupou a cadeira de número 8 na Academia Pernambucana de Letras (APL) e atuou profissionalmente como tradutor e escritor. Foi membro da Sociedade Brasileira de Médicos Escritores (SOBRAMES), da Academia de Letras e Artes do Nordeste e da União de Médicos Escritores e Artistas Lusófonos (UMEAL). Publicou em 2005 a tradução dos 154 sonetos de Shakespeare por conta própria, o que significa dizer que a publicação foi custeada pelo próprio tradutor. De igual maneira, publicou o volume Pequenas traduções de grandes poetas em 2006, o qual mais tarde, em 2010, recebeu o prêmio de tradução pela APL. Nesse trabalho mais recente, dentre os autores traduzidos, se encontram alguns dos sonetos shakespearianos traduzidos um ano antes.

Segundo a análise realizada pelo blog Casa da Bibliofilia acerca das traduções dos sonetos do Bardo por Milton Lins, é possível verificar algumas críticas severas a respeito de suas escolhas tanto lexicais quanto ao nível estrutural da mancha gráfica. Conforme os comentário do blog não há, na sua 
introdução, uma proposta tradutória explícita, e isso obscurece o entendimento de suas preferências. Observam-se, por exemplo, traduções ora em decassílabos, ora em dodecassílabos, e o tradutor acrescenta e subtrai versos em seu volume com a intenção de preservar as rimas. Reproduzimos a seguir o soneto 121 da sequência, para demonstrar a estratégia empregada:

\section{Sonnet 121}

'Tis better to be vile than vile esteemed,

When not to be receives reproach of being,

And the just pleasure lost, which is so deemed

Not by our feeling, but by others' seeing.

É melhor ser um vil que um vil bem estimulado;

Sem mais o ser, terás censuras por ter sido.

Justo o prazer perdido, assim estão julgado

Por sentimento, não; por algo deduzido.

Vale ainda comentar que o primeiro soneto da sequência traduzido por Milton Lins, ao que parece, tem o terceiro verso criado apenas para realizar a rima com o primeiro, que se traduz: "extenda-se a linhagem exemplar" e, então, a rima: "Ao passo que o mais sábio não somar". Vê-se, dessa forma, uma distância com os versos originais, que são lidos: "From fairests creatures we desire increase" e o terceiro verso: "But as the riper should by time decease" 39 .

Acerca da mancha gráfica dos sonetos, observa-se curiosamente que cada quadra é traduzida de maneira interlinear, ou seja, a quadra em português é seguida do original em inglês até o final do poema, o que pode dificultar a leitura do soneto como um todo, levando a crer inclusive que o

\footnotetext{
39 Exemplo extraído do blog Casa da Bibliofilia. Disponível em: http://casabibliofilia.blogspot.com/2011/05/sonetos-de-shakespeare-trad-milton-lins.html. Acesso em: 15 jun. 2020.
} 
tradutor desconsidera o fato de que um leitor sem o domínio da língua de partida pode não realizar o cotejo.

O contexto literário em que a publicação dos sonetos traduzidos por Lins se insere é o pós-modernismo. Nas estratégias tradutórias empreendidas pelo tradutor, parece haver uma aproximação com as ideias de Horácio sobre a licença poética, que será vista em Pisetta (2018), em que o tradutor, assim como o poeta, se permite o uso de certas "liberdades". Sendo assim, o tradutor lança mão de dois tipos de versificação (decassílabo e dodecassílabo), verificando-se uma possível proximidade com a conjuntura literária atual, em que há uma pluralidade de formas convivendo harmonicamente e cada tradutor lançará mão daquelas que julgar necessárias para alcançar os objetivos da tradução.

\section{Thereza Christina Rocque da Motta}

Thereza Christina é poeta, escritora, advogada e editora (fundadora da Ibis Libris). Em 2006, em razão da comemoração dos 400 anos do nascimento de Shakespeare, publicou pela sua própria editora a tradução de 44 sonetos selecionados, como ressalta em seu título William Shakespeare - 44 sonetos escolhidos, bem como em seu prefácio. A autora aponta que, em perspectiva oposta à de alguns tradutores dos sonetos shakespearianos que respeitam estritamente os aspectos formais, sua tradução prioriza o conteúdo ao invés da forma, isto é, observa mais a semântica do poema do que as características formais do soneto, visando atender a um público mais abrangente, formado também por aqueles que não possuem um certo hábito da leitura de poesia. A tradutora ainda vai além, pois destaca que a força que Shakespeare pôs em seus sonetos transcende todo formalismo, sinalizando, portanto, reiterar uma estratégia tradutória orientada principalmente ao conteúdo dos sonetos shakespearianos. Nesse sentido, para ela, os versos devem revelar a poesia e não aprisioná-la. Outros tradutores também assumem um posicionamento similar ao de Motta, quando afirmam que nem Shakespeare seguiu estritamente os aspectos formais do soneto inglês, como salientam Mendes 
(1969) e Dourado (2017) em seus paratextos, informando que suas traduções são realizadas a partir do que "sentem" nos sonetos em inglês.

Em 2009, em razão dos 400 anos da primeira edição da publicação dos sonetos do Bardo (1609), Motta publicou a tradução dos 154 sonetos pela mesma editora que já havia publicado os seus trabalhos anteriormente, lbis Libris. Assim como propusera em 2006 nos 44 sonetos, busca preservar a semântica em detrimento dos aspectos formais, justificando que a beleza do poema se manifesta quando não o aprisionam.

Em ambas as publicações (2006 e 2009), Motta afirma com veemência que não se preocupa em "amoldar os sonetos", e que seu objetivo primordial é traduzi-los da maneira que os sente, trazendo a mesma beleza da línguafonte para a alvo. Portanto, é notório para o leitor que suas traduções não seguem estritamente um padrão rímico, nem métrico, embora a mancha gráfica do poema esteja disposta em 14 versos, como no original. No que tange aos aspectos semânticos, a tradutora afirma que, por vezes, teve de excluir o que julgou não ser relevante em português e, muitas vezes, traduziu "o que o autor quis dizer" (2009, p. 16), argumentando que a tradução está repleta de um jogo de escolhas de sentido e relevância. Esse posicionamento se aproxima daquele defendido por Wanderley (1991), que julga haver uma relação de negociação no ato tradutório. Porém, para ele, diferentemente de Motta, os aspectos formais são primordiais durante a tradução de poesia, mesmo que seja preciso negociar o material semântico (WANDERLEY, 1991, p. 20). Ainda assim, Motta argumenta que, se tivesse observado estritamente a métrica e a rima, bem como os elementos semânticos do original, não teria obtido o mesmo resultado no seu trabalho. A título de ilustração, observe-se a primeira quadra do soneto 31 no original, seguida da tradução de Motta (2009):

\section{Sonnet 31}

Thy bosom is endearèd with all hearts, Which I, by lacking, have suppòsed dead, And there reigns love, and all love's loving parts, And all those friends which I thought burièd. 
Teu peito contém todos os corações, Que eu, por não os ter, supus mortos;

E onde reina o amor, e tudo o que o amor mais ama, E todos os amigos que pensei jazidos.

Por fim, o período da publicação do volume dos sonetos shakespearianos traduzidos se situa no pós-modernismo, quando a liberdade de expressão e as múltiplas formas são mais evidentes, como já observado. Certamente, a escolha estilística dependerá da proposta que um tradutor ou escritor deseja adotar, bem como sua perspectiva acerca do que é tradução.

\section{Jorge Furtado e Liziane Kugland}

Jorge Furtado é um cineasta brasileiro com ampla atuação na televisão e no cinema e, segundo o site ebiografia, é uma das referências de roteiristas e diretores com premiação no país. Ele também atuou no meio acadêmico lecionando sobre cinema e participou de diversas palestras e seminários, oferecendo cursos e oficinas na área.

Liziane Kugland é mestre em Letras pelas UFRGS, onde estudou versão, tradução e cinema. Segundo o seu Currículo Lattes, participou de eventos e conferências sobre tradução, bem como pesquisou sobre Lewis Carroll, o criador de Alice no País das Maravilhas.

Em 2010, ambos coorganizaram um volume com traduções de sonetos de Shakespeare, cujo título é: Sonetos de Shakespeare: faça você mesmo, publicando-o pela editora Objetiva, com todos os direitos autorais doados a UNICEF. A proposta desse trabalho foi convidar diversos artistas brasileiros, como Lázaro Ramos, Fernanda Torres, Clarisse Falcão e até mesmo o tradutor Ivo Barroso para realizar as traduções. Além disso, o leitor é estimulado a fazer sua própria tradução no verso de cada página do volume, podendo cotejar com a língua de partida e verificar as soluções tradutórias de cada artista. Por isso, há 14 versos em branco para o leitor experimentar a 
tradução dos sonetos shakespearianos. Importante também comentar que não há prefácio nem posfácio no volume, e o formato é bilíngue, às vezes contendo a tradução de um mesmo soneto por dois colaboradores.

O que antecede o conjunto dos sonetos traduzidos são algumas notas acerca do soneto shakespeariano de cunho didático e convidativo, que trazem pequenos textos como "Por que o soneto é mais interessante que sudoku?", escrito por Furtado; "Para fazer um soneto", por Furtado; "Estatuto do soneto", por Kugland e "Memorabilia", por Ivo Barroso, no qual ele comenta as suas experiências como tradutor de Shakespeare. O primeiro título propõe fazer uma comparação e contraste entre o soneto e o sudoku, que demonstra ter milhares de combinações possíveis, da mesma maneira que o soneto, mas que se formam por meio de números e não por palavras que, segundo Furtado, são mais cativantes. Além disso, ele salienta que a tradução é livre, e o que está em jogo é a diversão, embora Kugland, nas páginas seguintes, explique brevemente como se realizar um soneto seguindo o esquema do pé iâmbico e os aspectos formais da versificação shakespeariana.

Para Kugland, o que mais importa é o som de como as palavras são ditas, pois "tudo começa com o ritmo" (KUGLAND, 2010, p. 13), o que sinaliza uma proximidade com a noção tradutória de Jorge Wanderley (1991), que acredita que a musicalidade é um importante aspecto do ato tradutório. Todavia, Kugland salienta o mesmo que Barbara Heliodora (2000) e Oscar Mendes (1969), quando afirma que "cada língua tem seus encantos" (KUGLAND, 2010, p. 15), e ainda que "nem Shakespeare foi tão rigoroso" (p.16), reivindicando a liberdade defendida por Mendes (1969), Motta (2006; 2009) e Dourado (2017), entre outros. Afinal, para Kugland (2010, p. 17), desde que haja poesia "vale inverter as rimas, inverter o pé, trocar a métrica, até não rimar [...] fazer nossas ofertas e entrar em acordo". Essa defesa põe em evidência mais uma vez uma aproximação a Wanderley (1991), que entende a tradução como um constante processo de negociação. Ilustra-se aqui a primeira quadra do soneto de número 14 no original, acompanhada da (co)tradução feita pelo ator Lázaro Ramos e Jorge Furtado: 
Sonnet 14

Not from the stars do I my judgement pluck,

And yet methinks I have astronomy,

But not to tell of good or evil luck,

Of plagues, of dearths, or seasons' quality;

Não colho julgamentos das estrelas

Embora saiba um pouco de astronomia

Notícias boas, más? Não sei prevê-las

Nem sei da fome que trarão os dias

O volume organizado por Furtado e Kugland se insere dentro do momento literário do pós-modernismo que, como já dito, não prescreve regras formais específicas. Observa-se, no entanto, que os organizadores dão importância ao esclarecimento do funcionamento do sistema dos sonetos, bem como dos sonetos shakespearianos, ressaltando as características dessa forma fixa.

\section{Geraldo Carneiro}

Poeta, dramaturgo, letrista e roteirista, o mineiro Geraldo Carneiro estudou na Pontifícia Universidade Católica do Rio de Janeiro (PUC-Rio) e participou ativamente do fenômeno cultural da Poesia Marginal, ou "geração mimeógrafo", que surgiu em função da censura imposta pela ditadura militar nos anos 1970. Esse fenômeno cultural promoveu a busca por métodos alternativos e não aceitos "oficialmente" para a difusão de obras literárias. Assim, os poetas faziam uso de mimeógrafos, que eram a tecnologia alternativa de divulgação da época. A denominação "poesia marginal", então, surge como sinônimo de poesia divulgada por meios não convencionais (NETO, 2018).

Em 2012, pela editora Nova Fronteira, Geraldo Carneiro publicou um livro de capa dura intitulado $O$ discurso do amor rasgado - poemas, cenas e 
fragmentos de William Shakespeare, em que busca resgatar fragmentos sobre o tema amor nos textos do poeta inglês, seja nas obras dramáticas ou líricas, apresentando assim, a tradução dos sonetos 76, 18, 15, 65 e 116, cuja ordenação intercala com os trechos dramáticos. Tanto os sonetos como os demais fragmentos estão dispostos em formato bilíngue, tornando possível sua leitura em ambos idiomas. Há uma nota introdutória feita pelo tradutor e um posfácio assinado por Nelson Ascher, seguido de cinco notas explicativas.

Na breve introdução de uma página e meia, Geraldo Carneiro manifesta as circunstâncias nas quais suas traduções das obras teatrais de Shakespeare foram solicitadas. A sua primeira tradução de uma peça shakespeariana, $A$ tempestade, foi encomendada pelo grupo teatral Pessoal do Despertar, criado pela atriz e produtora Maria Padilha, que posteriormente, solicitou uma outra tradução, a da peça As you like it, que permanece inédita. O tradutor comenta que, além dessas traduções, houve encomendas de Trabalhos de amor perdidos, Antonio e Cleópatra e Romeu e Julieta, igualmente inéditas. Tomando essas traduções como aventuras, afirma que resolveu se arriscar na tradução de alguns sonetos shakespearianos, por já ter uma "intimidade com o Bardo" (CARNEIRO, 2012, p. 10). Cabe informar aqui que em 2019 foi lançada a sua tradução de Hamlet, em prosa e versos decassílabos, pela editora Maneira.

Em tom de entusiasmo pelo poeta inglês, assegura "Hoje percebo que, sem Shakespeare, meu mundo seria muito mais pobre de espírito, de humor e de poesia" (ibid.), sinalizando, assim, uma relação pessoal de autor-tradutor. Carneiro atribui a permanência do Bardo e de seus trabalhos ao longo do tempo e por toda parte ao poder de suas palavras, principalmente aquelas que versam sobre o amor. Heliodora (2000) também assume essa postura, quando justifica a seleção dos sonetos para o seu volume traduzido, afirmando ser a temática do amor a que mais perdurou no tempo. Ressalta, ainda, que o "amor" encontrado nos sonetos de Shakespeare transcende os modelos mais tradicionais, porque, segundo ela, o autor inglês expressou o "amor em todas as suas formas" (HELIODORA, 2000, p. 15), e aqui se entende uma extensão 
desde as formas mais comuns à época, como o amor pelo "ser humano, amor romântico, amor entre marido e mulher, entre pais e filhos [...] amor à pátria $\mathrm{e}$ à paz" (ibid.). Pode-se complementar que tal sentimento contempla também o amor homoafetivo e o amor mais carnal, figurado pelo desejo, como reconhecem Dourado (2017) e Funck (2019).

Carneiro conclui seu prefácio afirmando que não se comprometerá a discorrer a respeito dos infindáveis debates sobre a vida e a obra do autor inglês, nem utilizará de notas de uma erudição que não possui. Pretende sobretudo dar evidência à "Eros-dicção do Bardo"40 (CARNEIRO, 2012, p. 11), sendo esse o fim último das traduções reunidas em seu volume.

Já o objetivo do posfácio do poeta Nelson Ascher é fazer um breve resumo das produções de Shakespeare focando principalmente no teatro e na sua linguagem, estabelecendo um panorama de sua obra na Europa e no Brasil, lembrando que as primeiras traduções da obra do Bardo advinham, a princípio, do francês, sendo que a partir do século $X X$ passaram a ser traduzidas diretamente do inglês para o português brasileiro. Nesse recorte, Ascher sinaliza que o poeta Geraldo Carneiro é "seguramente o mais apaixonado que já tivemos pelo Bardo" (ASCHER, 2012, p. 129), esclarecendo que essa afirmação se embasa na sua evidente "anglofilia literária" (ibid.), bem como no seu "antigo e ativo convívio com o teatro e outras formas dramáticas" (ibid.). Vale refletir, no entanto, que de igual maneira o professor e tradutor dos sonetos de Shakespeare Almiro Pisetta (2018) é retratado como um apaixonado pelo Bardo, segundo afirmam Lázaro Polar e Leandro Karnal que assinam, respectivamente, o preâmbulo e o prefácio da obra traduzida, que será analisada posteriormente. Crê-se, portanto, que esse recurso discursivo vise creditar relevância aos trabalhos dos tradutores.

Sobre a tarefa tradutória, Ascher (2012, p. 130) salienta que não há tradução definitiva, sobretudo na tradução de poesia, pois embora haja uma versão produzida na língua original, na língua para a qual se traduz há uma

40 Para Geraldo Carneiro, o termo Eros-dicção refere-se à habilidade que Shakespeare tem de utilizar palavras que tocam profundamente o ser humano, de maneira que provoca neste paixões. 
infinidade de versões. Também aponta que o volume, longe de ser uma obra que traduz apenas fragmentos aleatórios, é resultante daquilo que Geraldo Carneiro pôde aprender com o poeta inglês, e nessa relação pode-se verificar a recriação em português pelo poeta-tradutor.

Geraldo Carneiro traduz em uma linguagem mais coloquial, sem muita erudição, como afirma na sua introdução. Em termos formais, o tradutor busca observar os 14 versos, rimando-os alternadamente na estrutura abab cdcd efef gg, seguindo um esquema de decassílabos, cujo desfecho se encontra no dístico de rimas emparelhadas. Observe-se, por exemplo, a primeira quadra do soneto 76 no original, acompanhada da tradução de Geraldo Carneiro:

\section{Sonnet 76}

Why is my verse so barren of new pride?

So far from variation or quick change?

Why with the time do I not glance aside

To new-found methods and to compounds strange?

Por que meu verso é sempre tão carente

De mutações e variação de temas?

Por que não olho as coisas do presente

Atrás de outras receitas e sistemas?

É curioso ainda mencionar que, entre os sonetos e os fragmentos dramáticos, encontram-se páginas de trechos traduzidos em formato bilíngue, cuja formatação foge do padrão estabelecido pelo tradutor. As palavras em fontes maiores chamam a atenção do leitor para a informação que trata obviamente do amor, mas não há ocorrência de qualquer explanação a respeito. Ainda assim, Carneiro busca aderir às normas estéticas do soneto inglês, buscando proximidade com os seus elementos rítmicos e rímicos. 


\section{Oscar Dourado}

Conforme os dados biográficos disponíveis em seu site ${ }^{41}$, o baiano Oscar Dourado é professor emérito da Universidade Federal da Bahia (UFBA), onde lecionou principalmente nas áreas das Artes Musicais, além de ser músico flautista. Todavia, sua carreira começou de maneira bem distinta, pois foi fotógrafo amador na década de 1980 e posteriormente, em 2008, cursou fotografia e linguagem audiovisual. É mestre em música pela Universidade de Massachusetts e doutor em artes musicais pela Universidade do Sul da Califórnia em Los Angeles. Tem quatro livros publicados, entre eles, dois de contos, uma coletânea de poemas e a tradução dos sonetos de Shakespeare.

Em 2017 publicou na Bahia as 154 traduções dos sonetos de Shakespeare pela P55 Edições, em formato monolíngue. Essa publicação episódica ${ }^{42}$ conta com uma apresentação em formato de notas introdutórias, nas quais o tradutor busca assinalar a expressividade linguística do Bardo, sobretudo na sua obra lírica Os Sonetos. No entanto, exime-se do trabalho de esmiuçar temas explorados por estudiosos do poeta inglês no que diz respeito, por exemplo, aos detalhes quanto a sua vida, contexto histórico, data dos sonetos, fontes dos sonetos etc., pois, segundo Dourado, em seu volume dos sonetos traduzidos, "abordá-los aqui [na introdução] se torna totalmente despropositado" (p. 2), dedicando-se, dessa maneira, aos elementos mais necessários à compreensão da leitura (ibid.).

O tradutor afirma ser Shakespeare um poeta subversivo em diversas circunstâncias, já que alguns sonetos não seguem o formato consagrado, nem quanto à métrica e rima, nem quanto ao desenvolvimento do tema, como será visto a seguir. Por exemplo, salienta que o soneto de número 126 não apresenta o couplet, isto é, o dístico; que há rimas não tão regulares nos sonetos 14, 51, 72, 87 e 126. Todavia, o tradutor Pisetta (2018) e o estudioso

\footnotetext{
41 DOURADO, Oscar. Biografia do professor Oscar Dourado Disponível em: https://www.oscardourado.com/. Acesso em: 20 jun. 2020.

42 Pelo Facebook, o tradutor respondeu que não houve uma motivação externa e sim interna, já que gosta de literatura e como professor de Artes Musicais trabalha com literatura. Pretende talvez futuramente publicar a tradução de outras obras do Bardo (Cf. Apêndice B - Entrevista com o tradutor Oscar Dourado).
} 
Spiller (1992) sustentam a ideia de que o soneto 126 não é exatamente um soneto, mas um poema produzido somente por dísticos.

Sobre o desenvolvimento das ideias, Oscar Dourado assegura que Shakespeare muitas vezes não observa o modelo convencional, buscando proceder de maneira inconclusiva e até suspensiva. Para o tradutor, o único elemento mantido incessantemente em toda obra dos sonetos é o dístico final, já que esse recurso assinala "a 'verdade' do poema, e muitas vezes surpreende, assegurando êxtase à leitura" $(2017$, p. 6). Em outras palavras, o que o tradutor baiano afirma é que a função do dístico tem um caráter arrematador nos sonetos, o que já fora sinalizado por Spiller (1992). Além disso, Dourado frisa que há uma dualidade quase que ambígua nos poemas do Bardo, uma vez que essencialmente os sonetos se propõem expressar praises (louvores). Contudo, essa característica se transforma diversas vezes em lament (lamento) repleto de tristezas, sofrimento e angústia. Vale ainda destacar o aspecto antagônico exposto pelo tradutor, que revela ser um traço com forte presença na construção das imagens e expressão dos conflitos intercorrentes dos sonetos do poeta inglês. Essa peculiaridade da escrita shakespeariana revela uma correspondência com os sonetos de Petrarca, a quem inclusive Spiller (1992) enuncia como o primeiro na literatura europeia a explorar uma instabilidade semântica como traço constitutivo de seus sonetos.

Sobre suas estratégias e noções tradutórias, seguindo mais a face subversiva do autor inglês, o tradutor assegura que a pontuação do original é mantida nos casos em que a considera estrutural; já nas demais circunstâncias, opta pelas regras do vernáculo. Ele entende que, nos sonetos ingleses, sobretudo os do Bardo, geralmente cada quadra termina com uma pontuação de parágrafo, e cada verso se separa por vírgula ou ponto e vírgula, salvo nos casos em que há uma indagação ou enjambement - a quebra de verso ou divisão de uma sentença que se estende até o verso seguinte, sem respeitar, portanto, os limites dos sintagmas impostos pela forma. Frisa, também, as consequências resultantes de suas escolhas tradutórias, como é o caso do argumento da impossibilidade de manter o ritmo do pentâmetro 
iâmbico, pois o repertório linguístico monossilábico e dissilábico do inglês é superior ao do português; também revela a dificuldade dos decassílabos, pois, caso optasse por eles, resultaria no empobrecimento excessivo do conteúdo poético, "banalizando-o, superficializando-o, distorcendo-o" (p. 9), e justifica que "o próprio Shakespeare não parece dispensar tanto rigor no que se refere ao convencional estabelecido..." (p. 9). Esclarece, assim, sua preferência pelos versos brancos de rimas mais ou menos regulares, buscando também uma regularidade estrutural no que concerne ao número de versos e da disposição da mancha gráfica. Ademais, por sua própria iniciativa, numera o quinto e o nono verso, indicando o início do segundo e do terceiro quarteto, que leva a crer ser um recurso meramente orientador para um leitor inexperiente. Afirma, ainda, que o esquema de rimas - não tão regulares - que se esforça em seguir, sucede no "resultado melódico rítmico compensatório" (p. 9). A seguir, apresentamos a primeira quadra do soneto 18 no original, seguida da tradução de Dourado:

\section{Sonnet 18}

Shall I compare thee to a summer's day?

Thou art more lovely and more temperate:

Rough winds do shake the darling buds of May, And summer's lease hath all too short a date;

Desejaria comparar-te a um dia de estio?

Serias mais amável e com mais recato:

Rudes ventos tanto movam os delicados botões de maio,

E a folga de verão tenha prazo tão limitado.

Em suas traduções há a predominância dos tempos verbais do futuro do pretérito e do modo subjuntivo, os quais classifica como os tempos dos sonetos, já que esses expressam com mais propensão e suavidade a condicionalidade dos sonetos, bem como as complexas situações experienciadas pelo poeta, que de certa maneira, fazem referências a fatos e 
eventos duvidosos ou até mesmo irreais, apoiando-se em possíveis realidades idealizadas (DOURADO, 2017, p. 10). Por outro lado, justifica o uso do presente do indicativo em três circunstâncias, a saber: "[...] nas conversas entre o poeta e sua imagem no espelho, quando se dirige diretamente às personagens mitológicas, e quando interage com suas visões/alucinações noturnas" (p. 12). Assim, emprega um linguagem específica para se referir às recorrentes situações idealizadas, e outra, diferente, para os episódios periféricos.

Além das concepções que norteiam o seu projeto tradutório, verifica-se a conservação dos traços marcantes do Renascimento, como as referências a figuras mitológicas greco-romanas e a atenção voltada para as questões mais humanas, em detrimento do aspecto transcendental e religioso, dentre outras características. O tradutor, por sua vez, assegura que se debruçou sobre a complexa tarefa de verter para o português a expressividade e intensidade de uma linguagem afetiva a qual o Bardo soube tão bem utilizar. Confessa, por fim, o seguinte: "todo empenho desta tradução está voltado para proporcionar a devida importância que esta obra merece e que, infelizmente até hoje, não havia recebido entre nós" (DOURADO, 2017, p. 15). Vale pontuar que Oscar Dourado esclarece, pela rede social Facebook, que sua assertiva refere-se à tradução da obra Os Sonetos no contexto nacional, afirmando que desde a segunda metade do século $X X$ não houve uma tradução integral dos sonetos, referindo-se a traduções parciais como as de Ivo Barroso e de Barbara Heliodora, concluindo que a sua é a primeira, nesse intervalo de tempo, que contemplou toda a sequência. Todavia, esse argumento não se sustenta, ao se levar em consideração os dados levantados neste trabalho. Verifica-se, por exemplo, a tradução dos 154 sonetos por Jerônimo de Aquino (1956); Oscar Mendes (1969) e Jorge Wanderley (1991), todos publicados em data anterior à edição com as traduções de Dourado.

O contexto literário no qual se insere a publicação do tradutor baiano é certamente o pós-modernismo, em meio ao qual as características se voltam geralmente para a multiplicidade de estilos e temas na poesia. Especula-se, 
portanto, que sua opção pelos versos brancos e um esquema rímico mais ou menos regular decorre de uma postura mais "livre", sem um culto reverente à forma. Outro exemplo pode ser verificado no fato de abordar com liberdade as relações homo e heterossexuais nos sonetos 35 e 145, respectivamente.

\section{Almiro Pisetta}

Segundo o seu Currículo Lattes, Almiro Pisetta é doutor em literatura inglesa e mestre em linguística. Professor universitário, já atuou nas áreas da literatura inglesa e tradução em diversas instituições acadêmicas, como a PUC/SP, o Centro Universitário Ibero-Americano, a USP, entre outras. Há várias publicações registradas em seu Lattes, incluindo trabalhos apresentados em congressos e traduções realizadas, dentre elas a obra Senhor dos Anéis (1994) de J.R.R. Tolkien, cotraduzido por Lenita Maria Rimoli Esteves.

Em 2018, Pisetta publicou as traduções dos 154 sonetos de Shakespeare pela editora Martin Claret em formato bilíngue. O volume conta com um preâmbulo, um prefácio, uma introdução e uma dedicatória, respectivamente. Na primeira seção, um texto assinado por Lázaro Polar apresenta o volume e o tradutor. Há também a explicação sobre o nome tradutor, que se encontra na capa da obra. Polar revela ter sido informado pelo próprio tradutor que as siglas "W.S." incorporadas ao seu nome na capa "Almiro W.S. Pisetta" - referem-se a "William Shakespeare". O argumento de Pisetta é que os sonetos em português são de sua autoria, sendo, portanto, suas as decisões quanto aos aspectos formais e semânticos no vernáculo, mas que o conteúdo, as imagens e a sonoridade são da autoria de Shakespeare, de quem ele buscou obstinadamente uma compreensão para poder realizar as traduções dos sonetos. Na segunda seção, Leandro Karnal, professor e amigo desse tradutor, fornece mais algumas informações sobre Shakespeare e também acerca da carreira e das traduções de Pisetta, informando que a ideia de organização das traduções segue um esquema de 
três espelhos: o original em inglês, "uma versão poética e uma mais literal"43. Dessa forma, o volume oferece, para cada soneto, uma tradução em verso e outra em prosa, seguida de um número considerável de comentários acerca das escolhas lexicais do tradutor, bem como de explicações, as quais se encontram nas notas de rodapé. Já na introdução, o próprio tradutor faz considerações, discorrendo acerca do contexto sociocultural, estabelecendo 1609 como a data da primeira edição publicada, seguidas de uma análise das "entidades personificadas" e dos personagens que estão envolvidos no "drama subjacente em Os sonetos" (p.18), a saber: o Tempo, a Morte e a Natureza; e o Belo Rapaz, a Dama Escura e o Poeta Rival.

Acerca de suas concepções de tradução, Pisetta, nesse paratexto introdutório, ressalta que se embasa nas postulações de Ezra Pound (18851972), Paulo Vizioli e Horácio (65 a.C - 8 a.C), e desenvolve consideráveis reflexões teóricas acerca da tarefa tradutória, sobretudo no que tange às formulações de Ezra Pound das '“três atividades principais' da criação poética" ( p. 29), que foram traduzidas por Vizioli como as "três atividades principais' da tradução de poesia" (p. 29), a saber: melopeia, fanopeia e logopeia. Pisetta explana que a melopeia visa à observância do ritmo, que constitui elemento intrínseco na linguagem poética. Mas ressalta que, na concepção de Vizioli, essa postulação já incorre em um problema, pois utilizar decassílabos - um forte candidato na correspondência do pentâmetro iâmbico segundo Wanderley (1991) - fará com que o tradutor disponha de menos palavras do que o idioma de partida, e que no caso de Shakespeare, caberá ao tradutor brasileiro o destinado infortúnio de sacrificar parte do ritmo ou do sentido. Essa concepção se aproxima da ideia de alguns tradutores ao lidar com a questão da correspondência formal em suas traduções, como por exemplo, Barbara Heliodora (2008), Silva Ramos (2008), Ivo Barroso (2015) e Oscar Dourado (2017), que afirmam ser o léxico da língua inglesa repleto de

$43 \mathrm{O}$ termo adotado por Leandro Karnal (p.12) de "versão" não segue o que se compreende neste trabalho, isto é, versão se dá por meio da atividade de transpor um texto em vernáculo para um idioma estrangeiro, segundo o Glossário de termos de edição e tradução organizado por Queiroz (2008). No caso de Pisetta, o que ocorre é a tradução dos sonetos de Shakespeare da língua-fonte, inglês, para a língua-meta, o nosso vernáculo. 
palavras monossilábicas e dissilábicas, o que possibilita versos mais curtos. Entretanto, Pisetta menciona que Vizioli assume uma postura de defesa do sentido em detrimento a outros aspectos formais; para Vizioli, o sentido é um elemento de primeiro grau de relevância.

A fanopeia, por sua vez, consiste em manter, ao máximo, as imagens do original e prezar pela conservação da atmosfera na qual o poema está imbricado; por exemplo, o autor esclarece que, em The Sonnets, o soneto de número 12 está repleto de imagens rurais, e caberá ao tradutor, nesse caso, buscar manter esses elementos em sua tradução. Diante disso, anacronismos ou as chamadas "liberdades" que o tradutor possa praticar não resultam em recriação poética, mas em adaptações (p. 30). Por fim, a logopeia resume-se na captação do registro do texto original, ou seja, o tradutor ${ }^{44}$ ressalta que, para Vizioli, não se deve verter um texto em linguagem coloquial, se o autor se expressa de uma maneira mais elevada e erudita, e vice-versa. Além de outros elementos, o tradutor deve observar sempre as múltiplas conotações e trocadilhos inerentes à linguagem poética durante a sua tarefa tradutória.

Além de adotar Vizioli como seu referencial teórico, o tradutor se embasa em Horácio no que concerne à postulação sobre a licença poética: "os pintores e poetas sempre tiveram com justiça a faculdade de cometer qualquer ousadia"45. Portanto, Pisetta lança mão de algumas "liberdades" e assume uma postura que permite ao tradutor de poesia "ousadias de tipo gramatical ou semântico; [...] o uso de arcaísmos e/ou anacronismos; [...] certas formulações lúdicas ou jocosas" (p. 37). Por exemplo, na tradução do quarto verso no soneto 130 de Shakespeare "If hairs be wires, black wires grow on her head", se verá "E o cabelo é bombril ${ }^{46}$ e escuridão"; ou a

\footnotetext{
${ }^{44}$ Pisetta afirma que, para Pound, a definição de logopeia é mais abstrata e complexa do que se verifica na tradução de Vizioli, a saber: "Pound redefine a logopeia como poesia que 'emprega palavras não por seu significado direto, mas [...] levando em conta especialmente seu uso habitual, o contexto em que esperamos encontrá-las"' (p. 33).

45 Tradução apresentada por Pisetta (p. 29).

46 O tradutor deixa claro que a solução tradutória "bombril" não foi adotada sem qualquer hesitação de ser encarada como um solução preconceituosa. Mas que sua ousadia foi menos literal e mais surpreendente que a dos tradutores anteriores, como é o caso de Jerônimo de Aquino (1956): "Como de arame preto é a cabeleira dela"; ou Oscar Mendes (1969): "Se arames são cabelo, arame negro a adorna" (p. 38).
} 
expressão "lero-lero" para traduzir "hearsay" no verso 13 do soneto 21 , como o próprio tradutor elucida (p. 37). Vale ressaltar que outros tradutores também lançaram mão dessa estratégia tradutória que, grosso modo, busca modernizar a tradução dos sonetos, como por exemplo, Milton Lins (2005) e os colaboradores do volume organizado por Furtado e Kugland (2010).

Em termos de versificação e das rimas, embora defenda a liberdade poética do tradutor, Pisetta opta pelos versos em decassílabos de rimas alternadas nas três quadras, seguidas de um dístico final de rimas emparelhadas, como no original inglês. Ao que parece, essa liberdade se aplica mais ao material semântico dos sonetos do que aos elementos formais. Veja-se, por exemplo, a segunda quadra do soneto 8 no original, seguido da tradução de Pisetta, onde é possível constatar a sua observância métrica e rímica:

\author{
Sonnet 8 \\ If the true concord of well-tunèd sounds, \\ By unions married, do offend thine ear, \\ They do but sweetly chide thee, who confounds \\ In singleness the parts that thou shouldst bear; \\ Sons concordes, em ótima harmonia, \\ Bem casados ofendem teu ouvido? \\ São queixas contra ti, que em tua folia \\ Em solo tens as partes confundido.
}

Vale salientar ainda que, curiosamente, Pisetta é o único tradutor que produz uma dedicatória e a insere ao lado daquela encontrada na obra dos sonetos de 1609. O tradutor não mantém o material semântico, mas conserva o tom misterioso identificado no volume original: 


\author{
À INSTIGANTE \\ LEITORA E DESTES SONETOS \\ INTÉRPRETE ORIGINAL \\ SEMPRE BONDOSA \\ REVISORA INFLEXÍVEL \\ ASSIM OS DEDICO: \\ LINDA LINDA MAIS QUE LINDA \\ ESTRELA FIXA IDEAL \\ NADA EXISTE EM TI E EM MIM \\ IMPEDINDO O QUE EU PREVI \\ TÃO EVIDENTE DESDE O ALBOR \\ AQUI O DECLARO: TE AMO E ADMIRO
}

Quanto ao contexto literário da publicação do volume traduzido, é notório que seja o pós-modernismo, e Pisetta parece lançar mão de tudo o que está a sua disposição nesta atual conjuntura literária a fim de atingir os objetivos tradutórios de seu volume. De fato, aproxima-se do que entende Hollanda (1998) acerca da hibridização das formas em relação à produção cultural. Verifica-se, por exemplo, nas suas estratégias, que emprega soluções mais "livres", visando criar surpresa no leitor, modernizando alguns vocábulos do soneto shakespeariano. Essas soluções estão fundamentadas no conceito de licença poética de Horácio. Mas, ao mesmo tempo, o tradutor não se exime de buscar uma aproximação dos aspectos formais do inglês, no que concerne à rima e à métrica. Embasando-se no que diz Wanderley (1991), "O som de um decassílabo (no caso o pentâmetro iâmbico) não é o som de um dodecassílabo ou outro qualquer" (p. 19), sinaliza sua preferência pela preservação dos elementos formais do poema. Corrobora, assim, o que foi trazido aqui por Britto (2013) no início deste capítulo acerca do pósmodernismo, que os poetas - nesse caso, tradutores de poesia - se sentem mais livres para fazer uso de repertórios técnicos deste ou daquele movimento 
histórico, e já não mais integram comunidades literárias específicas que antes se excomungavam mutuamente.

\section{Elvio Funck}

De acordo com os dados biográficos informados na edição traduzida dos sonetos de Shakespeare (2019), Funck interessou-se pela tradução durante a sua graduação, nos anos 1960. Em 1973, quando concluiu o mestrado, ingressou na UFRGS, onde atuou como colaborador na implantação do curso de tradutor e intérprete no departamento de Letras da universidade. Após a conclusão do seu doutorado em Literatura Inglesa em 1979, o tradutor salienta que se familiarizou com a tradução interlinear de textos dos séculos $X V$ e $X V I$ - sendo essa uma das razões de sua escolha para as traduções dos sonetos de Shakespeare, formato esse também usado nas suas traduções do cânone dramático. Quando ocupou a cadeira de inglês e literatura inglesa na Unisinos e na PUCRS, passou a estar em contato direto com as obras shakespearianas, bem como a realizar traduções interlineares e organizá-las para utilização em suas aulas. Nesse âmbito acadêmico, a maneira como traduziu o Bardo obteve sucesso entre os seus alunos, e foi o que o levou a publicar as traduções de Shakespeare nesse formato. Até 2020, Funck traduziu e publicou um total de 21 peças do cânone dramático, como mencionado, contemplando desde títulos mais populares, como Hamlet (2003), Macbeth (2006) e Romeu e Julieta (2012), até os menos conhecidos, como Rei João (2019) e Eduardo III (2010). Em 2019, publicou um volume com os 154 sonetos de Shakespeare, em tradução interlinear e em formato bilíngue, acrescida de diversas notas de rodapé no verso da página de cada tradução.

No paratexto de sua autoria que acompanha o volume, Funck comenta que suas traduções em prosa se comprometem mais com o que está escrito no texto de partida, do que com a forma como está escrito; logo, privilegia o sentido em detrimento da forma. Dessa maneira, afirma que suas traduções não são poéticas, porém salienta com veemência a importância do dístico, 
chamando-o de pequena composição poética que, para ele, é a "chave de ouro" (FUNCK, 2019, p. 11), pois julga necessário preservar o que chama de "pé-poético" (Ibid.). Dessa forma, o leitor de seus sonetos traduzidos encontra, no verso da página, soluções de outros tradutores para a copla feitas para a língua portuguesa, francesa e alemã - acrescidas de uma tradução livre em português brasileiro - pois, segundo Funck, a razão de fornecer outras traduções do dístico final foi "para dar uma visão mais universal do soneto e também porque são poucas as traduções dos sonetos para o português" (p.13). Além disso, vale salientar que, também nos versos das páginas, encontram-se notas explicativas com objetivo didático, onde Funck apresenta as conotações para um mesmo vocábulo - já que afirma que "em suas traduções" opta por traduzir os vocábulos em seu sentido denotativo e apresentar suas respectivas conotações nas notas explicativas. Pode-se também destacar o modo como o tradutor comenta as notas do soneto traduzido utilizando o "eu poético", já que salienta que não tem interesse em vincular as características, atitudes e sentimentos presentes no poema a aspectos da biografia de Shakespeare, embora reconheça que haja estudiosos que o fazem.

Outro fato que Funck traz à tona são as conotações e alusões eróticas figuradas, presentes nos poemas do Bardo. Segundo ele, a grande maioria dos poemas apresenta uma camada de erotismo, ora mais implícito, ora mais explícito, como é o caso dos sonetos 134, 135 e 136, cujo teor é mais erótico. Funck comenta, por exemplo, sobre a polissemia atribuída ao vocábulo will que, segundo ele, o Bardo emprega no sentido de desejo/vontade, mas que também pode conotar a genitália feminina. A título de ilustração, reproduzimos aqui a primeira quadra do soneto 134 no original, seguida da tradução de Funck:

\section{Sonnet 134}

So now I have confessed that he is thine, And I myself am mortgaged to thy will, 
Myself I'll forfeit, so that other mine

Thou wilt restore to be my comfort still:

Agora que admiti que meu amigo a ti pertence, fico comprometido a me conformar com tuas vontades e a mim mesmo me sacrifico, contanto que venhas a devolver meu outro eu para meu conforto:

O tradutor esclarece que a presença do amigo e da dama misteriosa no soneto 134 forma um triângulo amoroso com o eu poético, devido ao fato de que esse amigo havia sido um "intermediário" - responsável por conquistar a dama para o eu poético - no soneto anterior, e que acabou por se apaixonar por ela. Tal situação incorre em uma série de alusões sexuais, que se estendem até os sonetos 135 e 136. Funck, em suas notas, sugere uma tradução mais explícita do segundo verso: "tua pudenda fica hipotecada para meu uso futuro; agora quem usa é meu amigo" (p. 282). Contudo, reconhece que, consoante Stephen Booth (1977), o termo thy will, no segundo verso, também poderia conotar "teu William".

Embora Funck destaque as alusões eróticas nos três sonetos, ele se exime de discorrer sobre a questão da sexualidade de Shakespeare, abordada principalmente dentro dos queer studies, assegurando que durante o período elisabetano "a amizade forte entre homens era comum e socialmente aceita, sem necessariamente implicar colorações sexuais" (p. 12). Sendo assim, o autor descarta a possibilidade de comentar sobre as "relações sensuais" como chama Oscar Dourado (2017), isto é, relações homo e heteroafetivas, vistas respectivamente nos sonetos de número 35 e 141 (DOURADO, 2017). Todavia, ambos os tradutores concordam que os sonetos estão repletos de um teor erótico.

O momento literário da tradução de Elvio Funck se encaixa na mesma moldura contextual da poética brasileira de Almiro Pisetta que foi discutido no verbete anterior, ou seja, o pós modernismo. Funck, diferentemente de alguns 
de seus antecessores, opta por não aderir a qualquer sistema de normas em seu volume, seja da poética contemporânea do contexto de recepção, seja da poética adotada no texto-fonte, buscando uma estratégia de traduzir em prosa, como apresentado, apenas preservando os dísticos finais. Tal estratégia parece aproximar-se da postura adotada por tradutores como Mendes (1969), Motta (2006; 2009) e Dourado (2007), que buscam "enfatizar 'o que está escrito no texto-fonte', [e não "priorizar] 'como está escrito"' (FUNCK, 2019, p. 9), privilegiando assim, quase que integralmente o componente semântico dos sonetos shakespearianos. Além disso, é curioso notar que o tradutor não considera suas traduções como poéticas e atribui a característica de "males necessários" tanto às traduções como às notas explicativas em seu volume.

Concluímos, assim, o mapeamento do percurso tradutório dos sonetos shakespearianos no Brasil, até o presente momento, a partir dos dados sobre tradutores e traduções publicadas que nos foi possível localizar. A seguir, apresentamos as considerações finais. 


\section{CONSIDERAÇÕES FINAIS}

"Fair, kind, and true" is all my argument,

"Fair, kind, and true", varying to other words,

And in this change is my invention spent,

Three themes in one, which wondrous scope affords.

WILLIAM SHAKESPEARE (sonnet 105)

Esta dissertação pretendeu investigar o percurso tradutório dos sonetos shakespearianos produzidos e publicados em português do Brasil, desde 1905, data da primeira publicação, até hoje, ano de 2021, enfatizando as concepções e estratégias tradutórias adotadas pelos profissionais, para fins de reconhecimento e contribuição para a história dos tradutores e das traduções do poeta inglês no Brasil. Com preâmbulo para essa cartografia, a forma poética soneto foi abordada desde a sua gênese até a ocasião em que adentra o sistema literário da Inglaterra dos séculos XVI e XVII, buscando delinear a sua trajetória e destacando aqueles elementos temáticos e formais desenvolvidos pelos predecessores de Shakespeare que viriam a fazer parte do soneto inglês.

Em uma tentativa de sistematizar os dados obtidos, foram encontrados 18 tradutores e uma coletânea organizada, compondo assim, um total de 19 projetos de tradução dos sonetos de Shakespeare que respondem à indagação "Quem?" proposta por Lieven D'hulst (2010). Reconhece-se, no entanto, que haja outros tantos tradutores que se aventuraram nesta empreitada de traduzir os sonetos de Shakespeare, embora em publicações mais informais e esparsas. Além disso, buscou-se categorizar os tradutores aqui analisados de maneira cronológica, observando a data de suas publicações, a fim de corroborar o que fora dito anteriormente a respeito da obra de Shakespeare, ou seja, seus escritos perpassam por épocas e contextos bem distintos e sustentam a impressão de perenidade do autor e de suas obras.

Vale ainda ressaltar alguns aspectos observados acerca das traduções e dos tradutores. Ao analisar o contexto literário em que as traduções se inserem, por exemplo, muitas vezes não foi possível atestar uma influência 
direta dos respectivos contextos sobre as poéticas adotadas pelos diferentes tradutores num arco temporal de quase 12 décadas por dois motivos: os profissionais da tradução não explicitam esse aspecto em seus paratextos e metatextos, e também pelo fato de que tanto há traduções que preservaram estritamente os elementos formais e semânticos dos sonetos em inglês em um contexto estético de liberdade formal, quanto o oposto, isto é, o movimento literário estava orientado para uma observância da forma, e mesmo assim, o tradutor optou por uma tradução mais livre, o que caracterizaria uma subversão da estética dominante no sistema literário receptor.

Sobre os tradutores, ao observar seus paratextos e metatextos, alguns não comentam de maneira explícita suas concepções de tradução, que só puderam ser inferidas a partir da observação de suas estratégias tradutórias globais, como decisões sobre métrica e esquema rímico, e algumas soluções semânticas. Com base nas estratégias empregadas, pode-se informar que nove tradutores optaram pelos decassílabos; quatro adotaram os dodecassílabos; três utilizaram ora os decassílabos, ora os dodecassílabos; dois recorreram ao verso livre e um tradutor adotou a prosa para o seu volume. Quanto às rimas, 15 volumes seguiram as rimas regulares como no original e apenas quatro apresentaram rimas irregulares. Sobre os sonetos de maneira geral, oito profissionais realizaram as traduções de maneira integral. Em termos de gênero, identifica-se 15 tradutores e cinco tradutoras, incluindo nessa conta Jorge Furtado e Liziane Kugland, que coorganizaram o volume Sonetos de Shakespeare: faça você mesmo.

A julgar pelo interesse crescente que traduzir os sonetos do Bardo vem despertando em tradutores e poetas brasileiros - de 1905 a 2000, ou seja, no período de quase 10 décadas, 10 tradutores se dedicaram a essa tarefa, sendo que três traduziram a sequência completa; enquanto que de 2000 a 2019, ou seja, em duas décadas, nove tradutores (considerando a dupla Furtado e Kugland) já publicaram suas traduções dos sonetos, sendo que cinco deles traduziram a sequência completa - a expectativa é de que novas traduções continuarão a surgir, o que pode ser visto positivamente, uma vez 
que são visões diversas à disposição dos leitores. Vale recuperar aqui que a retradução dos clássicos, no caso, os sonetos shakespearianos, oferece uma variedade de concepções e produtos ao público leitor, oportunizando a constante ampliação da dimensão intertextual, diante da presença de paratextos e notas explicativas nos novos volumes publicados, confirmando o que frisa Funck (2019, p. 14) "quanto mais traduções dos sonetos tivermos, tanto melhor veremos Shakespeare". Além disso, tem a oportunidade de atualizar normas tradutórias, linguísticas e/ou editoriais consideradas ultrapassadas.

Por fim, vale reiterar que este trabalho realiza um abordagem panorâmica, de viés historiográfico, sem se deter na análise microtextual dos sonetos traduzidos - algo que seria impossível de se executar, diante do tamanho do corpus. Contudo, existe um vasto campo para pesquisadores que desejam se debruçar sobre todo esse material disponível acerca dos sonetos traduzidos para o português do Brasil, a fim de contemplar aspectos que julguem relevantes para os Estudos da Tradução ou Estudos Shakespearianos. 


\section{REFERÊNCIAS BIBLIOGRÁFICAS}

ACADEMIA BRASILEIRA DE LETRAS. Biografia de Geraldo Carneiro. Disponível em: http://www.academia.org.br/academicos/geraldocarneiro/biografia. Acesso em: $10 \mathrm{dez} 2019$.

ACADEMIA BRASILEIRA DE LETRAS. Prêmios Literários da ABL. Disponível em: http://www.academia.org.br/academia/premios. Acesso em: 17 jun 2020.

AGNES, Lilia L. C.; GUERINI, Andréia. Verbete Bárbara Heliodora Carneiro de Mendonça do Dicionário de Tradutores Literários no Brasil (DITRA). Florianópolis: NUPLITT - Núcleo de Pesquisas em Literatura e Tradução, UFSC, 2013.2 Disponível em: https://dicionariodetradutores.ufsc.br/pt/HeliodoraCarneirodeMendonca.htm. Acesso em: 25 fev 2021.

ALEIXO, José Carlos Brandi. Antônio Da Fontoura Xavier. Diplomata e Escritor. Historia Caribe, v. VI, núm. 18, 2011, p. 31-49. Universidad del Atlántico: Barranquilla, Colômbia. Disponível em: https://www.redalyc.org/pdf/937/93722645003.pdf. Acesso em: 19 mai 2020

ANAIS da Biblioteca Nacional, 1959, v. 79, p. 53. Disponível em: http://docvirt.com/Hotpage/Hotpage.aspx?bib=Anais BN\&pagfis $=10260 \& u r l=$ http://docvirt.com/docreader.net\#. Acesso em: 06 ago 2020.

ASSOCIAÇÃO NACIONAL DE ESCRITORES (ANE). Oscar Mendes. Disponível em: https://anenet.com.br/oscar-mendes/. Acesso em: 19 mai 2020.

BEGET. In: Merriam-Webster Online. Webster, Incorporated. [19-?]. Disponível em: https://www.merriam-webster.com/dictionary/beget. Acesso em: 09 set 2020.

BLOOM, Harold. Bloom's Shakespeare Through the Ages: The Sonnets. New York: Chelsea House, 2008.

BOSI, Alfredo. A literatura brasileira: o pré-modernismo. São Paulo: Cultrix, 1969.

BOSI, Alfredo. História concisa da literatura brasileira. 50ํㅡㄹ ed. São Paulo: Cultrix, 2015.

BOOTH, Stephen. Shakespeare's Sonnet. New Haven: Yale University Press, 1977. 
BOTTMANN, Denise. "Não gosto de plágio". 2008. Disponível em: http://naogostodeplagio.blogspot.com/2008 0801 archive.html. Acesso em: 09 jun 2020.

BRITTO, Paulo Henriques. A poesia brasileira hoje. 2013. Disponível em: http://www.letras.puc-

rio.br/media/filemanager/professores/paulo britto/Poesia\%20brasileira\%20ho e.pdf. Acesso em: 31 ago 2020.

BURCKHARDT, Jacob. A cultura do Renascimento na Itália: um ensaio. Trad. Vera Lúcia de Oliveira Sarmento e Fernando de Azevedo Corrêa. Brasília: Editora Universidade de Brasília, 1991.

BURGESS, Anthony. A Literatura Inglesa. Trad. Duda Machado. $2^{\underline{a}}$ ed. São Paulo: Ática, 1999.

CASA da Bibliofilia. Blog. Disponível em: http://casabibliofilia.blogspot.com/2011/05/sonetos-de-shakespeare-tradmilton-lins.html. Acesso em: 17 jun 2020.

CAMPOS, A.; CAMPOS, H.; PIGNATARI, D. Teoria da Poesia Concreta: Textos críticos e Manifestos (1950-1960). São Paulo: Duas Cidades, 1975.

CAMPOS, Haroldo de. Da tradução como criação e como crítica. In: Metalinguagem e outras metas: ensaios de teoria e crítica literária. São Paulo: Perspectiva, 1992, p. 21-38.

CAPELA, Carlos Eduardo Schmidt. Entre estentores, estertores e extensores da poesia, um agora. In: PEDROSA, Celia, e CAMARGO, Maria Lucia de Barros (orgs.) Poéticas do olhar e outras leituras de poesia. Rio de Janeiro: 7Letras, 2006, p. 195-204.

CARNEIRO, Geraldo. O discurso do amor rasgado: poemas, cenas e fragmentos de William Shakespeare. Rio de Janeiro: Nova Fronteira, 2012.

CARDELLINO, Pablo; COSTA, Walter Carlos. Verbete Geir Campos do Dicionário de Tradutores Literários no Brasil (DITRA). Florianópolis: NUPLITT - Núcleo de Pesquisas em Literatura e Tradução, UFSC, 2013. Disponível em: http://www.dicionariodetradutores.ufsc.br/pt/GeirCampos.htm. Acesso em: 11 ago. 2020.

COLLIN, Luci. O soneto shakespeariano. In: LEÃO, L.; SANTOS, M. (org.). Shakespeare, sua época e sua obra. Curitiba: Beatrice, 2008, p. 207-225.

CORDEIRO, Renata Maria Parreira. Currículo do sistema de Currículos Lattes. 
Disponível em: http://lattes.cnpq.br/7237084473636363. Acesso em: 17 jun. 2020.

. Sonetos ao Jovem Desconhecido. São Paulo: Editora Landy, 2003.

D'HULST, Lieven. Translation history. In: GAMBIER, Yves; VAN DOORSLAER, Luc. Handbook of translation studies. (eds) Amsterdam/Philadelphia: John Benjamins Publishing, 2010, p. 397-405.

DOURADO, Oscar. Biografia do professor Oscar Dourado. Disponível em: https://www.oscardourado.com/. Acesso em: 20 jun 2020.

DUNCAN-JONES, Katherine. Shakespeare's Sonnets. London: The Arden Shakespeare, 1997.

EDMONDSON, P.; WELLS, S. Oxford Shakespeare Topics: Shakespeare's Sonnets. New York: Oxford University Press, 2004.

EVANS, Gwynne Blakemore. The Sonnets. UK: Cambridge University Press, 2006.

FRANCO, Márcia Arruda. Sá de Miranda, trovador e poeta. Revista do Centro de Estudos Portugueses, v. 27, n. 37, p. 63-77, 2007. Disponível em: http://www.periodicos.letras.ufmg.br/index.php/cesp/article/view/6598. Acesso em: 15 mar 2020

FRAZÃO, Dilva. Biografia de Jorge Furtado. 2017. Disponível em: https://www.ebiografia.com/jorge furtado/. Acesso em: 27 ago 2020.

GALINDO, Caetano W. Shakespeare e a língua e a língua e Shakespeare. In: LEÃO, L.; SANTOS, M. (org.). Shakespeare, sua época e sua obra. Curitiba: Beatrice, 2008, p. 81-104.

GAMBIER, YVES; STECCONI, Ubaldo (org.). A World Atlas of Translation. Amsterdam: John Benjamins, 2019, p. 1-11.

GHIVELDER, D.; REIS L. F. Os 450 anos de Shakespeare. O Globo. Rio de Janeiro, 20 maio 2014. Disponível em: https://oglobo.globo.com/cultura/os450-anos-de-shakespeare-12244798. Acesso em: 15 set 2020.

GOMES, Eugênio. Shakespeare no Brasil. São Paulo: MEC, 1961.

GUEIROS, 2015 In: SHAKESPEARE, William. 50 Sonetos. Trad. Ivo Barroso. 5 ed. Rio de Janeiro: Nova Fronteira, 2015. Disponível em: http://www.lighthousebilingue.com.br/wp-content/uploads/2018/07/50Sonetos-William-Shakespeare.pdf. Acesso em: 23 fev. 2020. 
HELIODORA, Bárbara. Escritos sobre teatro. Org. Claudia Braga. São Paulo: Perspectiva, 2007.

HELIODORA, Barbara. Shakespeare Brasil. Disponível em: http://www.shakespeare.ufpr.br/entrevista-com-barbara-heliodora-sobreteatro-e-shakespeare/. Acesso em: 12 ago 2018.

HELIODORA, Barbara. Shakespeare no Brasil. In: LEÃO, L.; SANTOS, M. (org.). Shakespeare, sua época e sua obra. Curitiba: Beatrice, 2008, p. 321334.

HERMANS, Theo. The Manipulation of Literature: Studies in Literary Translation. London: Croom Helm, 1985.

HOLLANDA, Heloisa Buarque de. Introdução. In: antologia dos anos 90. Rio de Janeiro: Aeroplano, 1998 Esses poetas: uma HUSBANDRY. In: Merriam-Webster Online. Webster, Incorporated. [19-?]. Disponível em: https://www.merriam-webster.com/dictionary/husbandry. Acesso em: 09 set 2020.

HYLAND. Peter. An Introduction to Shakespeare's poems. New York: Palgrave Macmillan, 2002.

MORRE aos 86 anos o escritor, médico e tradutor Milton Lins, imortal da Academia Pernambucana de Letras. Diário de Pernambuco, Pernambuco, 08 mar 2015.2 Disponível em: https://www.diariodepernambuco.com.br/noticia/viver/2015/03/morre-ao-86anos-o-escritor-medico-e-tradutor-milton-lins-imortal-da-academiapernambucana-de-letras.html. Acesso em: 17 jun 2020.

MACHMAN, Flora. Chuva Miúda. Rio de Janeiro: Garamond, 2011.

MARTINS, Marcia A. P. A instrumentalidade do modelo descritivo para a análise de traduções: o caso dos Hamlets brasileiros. São Paulo: Programa de Estudos Pós-Graduados em Comunicação e Semiótica, PUCSão Paulo, 1999.

MARTINS, Marcia A. P. Base de dados "Escolha seu Shakespeare". Disponível em: http://www.dbd.puc-rio.br/shakespeare/index.htm. Acesso em: 31 mar 2020.

MARTINS, M. A. P. Traduções, retraduções e adaptações de clássicos no Brasil. Conferência de abertura do ENTRAD 2019 - VII Encontro Internacional de Tradutores e XIII Encontro Nacional de Tradutores, 7-11 de outubro de 2019, Universidade Federal da Paraíba, João Pessoa, PB. 2019 (inédito). 
MARTINS, M. A. P. Vozes femininas nas traduções brasileiras do drama shakespeariano. Webinário 6, VIII Seminário da História da Tradução e da Tradução Literária, $16 \quad$ nov $2020 . \quad$ Disponível em: https://www.youtube.com/watch?v=zuyCrp5yod4\&feature=share. Acesso em 25 nov 2020.

MASSARDIER-KENNEY, Françoise. Of forceful looking: New perspectives on retranslation. In: Brian James Baer (ed.). Translation and Interpreting Studies, v.15, Amsterdam/Philadelphia: John Benjamins, 2014, p. 299-308.

MELLO, Barboza \& MONAT, Olympio. William Shakespeare: edição do IV Centenário. Rio de Janeiro: Leitura, 1964.

MENDES, Oscar. Nota introdutória. In: SHAKESPEARE, William. Obras completas. Rio de Janeiro: Companhia José Aguilar, 1969, v. III, p. 735-737.

MORICONI, Ítalo. Como e por que ler a poesia brasileira do século XX. Rio de Janeiro: Objetiva, 2002.

MOISÉS, Massaud. Dicionário de Termos Literários. 12 ed. São Paulo: Cultrix, 2004.

NETO, Amador Ribeiro (org.). Poesia Marginal: antologia poética. 2018. Disponível em: http://www.cchla.ufpb.br/dlcv/contents/documentos/banco-de textos/amadorrnetoorgantpoesia-marginal.pdf . Acesso em: $10 \mathrm{dez} 2019$.

OLIVEIRA, Priscila Ott Falcão. Os Sonetos de Petrarca 47, 104 e 123: um estudo interpretativo da segunda versão para piano. Dissertação (Mestrado). Universidade Estadual de Campinas, Campinas, 2010.

ORGEL, Stephen. Introduction: Shakespeare the poet. In: EVANS, G. B. The Sonnets. UK: Cambridge University Press, 2006.

PEIXOTO, Sergio Alves. O Parnasianismo no Brasil: variações sobre um mesmo tema. Disponível em: http://www.periodicos.letras.ufmg.br/index.php/o eixo ea roda/article/viewFil e/3355/3285. Acesso em: 19 mai 2020.

PEREIRA, Durval Vieira et al. ARQUIVOS PESSOAIS E SUAS POTENCIALIDADES PARA PESQUISA: O caso do Arquivo Guilherme Figueiredo. Revista do Instituto de Ciência da Informação da UFBA, Bahia, v. 13, n. 1, p. 171-192, 2019. Disponível em: https://portalseer.ufba.br/index.php/revistaici/article/view/27540/19551.

Acesso em: 19 mai 2020. 
PINILLA, Jose A. S. A história da tradução no Brasil: questões de pesquisa. Tradução em Revista, [s.l.], v. 2020, n. 28, p. 13-31, 2020. Faculdades Católicas. http://dx.doi.org/10.17771/pucrio.tradrev.48156.

PISETTA, Almiro. Currículo do sistema de Currículos Lattes. Disponível em: http://lattes.cnpq.br/6033417622816399. Acesso em: 10 jun 2020.

PYM, Anthony. Method in Translation History. 2 ed. New York: Routledge, 2014.

QUEIROZ, Sônia (org.). Glossário de termos de edição e tradução. Belo Horizonte: $\quad$ Fale/UFMG, 2008.2 Disponível em: http://escritoriodolivro.com.br/bibliografia/glossarioedicaoetraducao.pdf.

Acesso em: 15 jun 2020.

RAMOS, Péricles E. da S. Introdução. In: SHAKESPEARE, William. Sonetos. Trad. Péricles Eugênio da Silva Ramos. 5aㅡ ed. Rio de Janeiro: Hedra, 2008, p. 9-41.

SHAKESPEARE, William. 44 Sonetos escolhidos. Trad. de Thereza Christina Rocque da Motta. Rio de Janeiro: Ibis Libris, 2006.

2015.

50 Sonetos. Trad. Ivo Barroso. $5^{a}$ ed. Rio de Janeiro: Nova Fronteira,

154 sonetos. Trad. Thereza Christina Rocque da Motta. Rio de Janeiro: Ibis Libris, 2009.

. Os sonetos. Trad. Oscar Dourado. Salvador: P55 Edições, 2017.

. Os sonetos de Shakespeare. Trad. Maria do Céu Saraiva Jorge. Lisboa: [s.n.], 1962.

. Poemas de amor de William Shakespeare. Trad. Barbara Heliodora. Rio de Janeiro: Ediouro, 2000.

2007.

Sonetos. Trad. Jerônimo de Aquino. São Paulo: Editora Martin Claret,

Sonetos. Trad. Jorge Wanderley. 2 ed. Rio de Janeiro: Civilização Brasileira, 1991. 2019.

Sonetos completos. Trad. Elvio Funck. Porto Alegre: Movimento, 
Sonetos de Shakespeare: faça você mesmo. Jorge Furtado e Liziane Kugland (org.). Rio de Janeiro: Objetiva, 2010.

. The sonnets of William Shakespeare e os sonetos de Almiro Pisetta. Trad. Almiro Pisetta. São Paulo: Martin Claret, 2018.

SMITH, C. B. A vida de William Shakespeare. In: LEÃO, L.; SANTOS, M. (org.). Shakespeare, sua época e sua obra. Curitiba: Beatrice, 2008, p.19-34.

SOUZA, Liziane Kugland de. Currículo do sistema de Currículos Lattes. Disponível em: http://lattes.cnpq.br/2594260014391947. Acesso em: 27 ago 2020.

SPILLER, Michael R. G. The development of the Sonnet. London: Routledge, 1992.

VENUTI. Lawrence. The Translator's Invisibility: A History of Translation. $2^{\mathrm{a}}$ ed. London and New York: Routledge, 2008.

. Translation Changes Everything: Theory and Practice. New York: Routledge, 2013.

VOLLET, Neuza L.R. Nobreza $x$ obscenidade em traduções brasileiras de Hamlet: uma reflexão sobre as relações possíveis entre os tradutores e o seu autor. Tradterm, [s.l.], v. 5, n. 2, p. 71-96, 1998. DOI: 10.11606/issn.23179511.tradterm.1998.49558. Disponível em: https://ww.revistas.usp.br/tradterm/article/view/49558. Acesso em: 20 jun 2020.

WALKER, Shanta Navvab. Para uma Tradução Comentada de Sonetos de Shakespeare. Brasília: Departamento de Línguas Estrangeiras e Tradução, Universidade de Brasília, 2018. Disponível em: http://repositorio.unb.br/bitstream/10482/33890/1/2018 ShantaNavvabWalker .pdf. Acesso em: 15 mai 2020.

WALLER, Gary. Edmund Spenser: A Literary Life. UK: Palgrave Macmillan, 1994.

WANDERLEY. JORGE. Dicionário de Tradutores Literários no Brasil. Disponível em: https://dicionariodetradutores.ufsc.br/pt/JorgeWanderley.htm. Acesso em: 09 ago 2019.

WARLEY, Christopher. Sonnet Sequences and Social Distinction in Renaissance England. UK: Cambridge University Press, 2005. 
WYLER, Lia. Línguas, poetas e bacharéis: Uma crônica da tradução no Brasil. Rio de Janeiro: Rocco, 2003.

XAVIER, Antônio V. F. Opalas. 2 ed. Lisboa: Viúva Tavares Cardoso, 1905. . Opalas. 4 ed. Rio de Janeiro: Graphica Sauer, 1928. 


\section{APÊNDICE A - Quadro panorâmico dos tradutores e de suas respectivas traduções dos sonetos shakespearianos publicadas no Brasil}

\begin{tabular}{|c|c|c|c|c|}
\hline Tradutor & $\begin{array}{c}\text { № de } \\
\text { Sonetos }\end{array}$ & Editora & $\begin{array}{l}\text { Noções de } \\
\text { Tradução }\end{array}$ & $\begin{array}{l}\text { Estratégia } \\
\text { Tradutória }\end{array}$ \\
\hline $\begin{array}{l}\text { Antônio V. da } \\
\text { F. Xavier }\end{array}$ & $\begin{array}{c}4 \text { sonetos dos } \\
154(14,17,21 \\
49)\end{array}$ & Opalas, 1905. & & $\begin{array}{l}14 \text { e } 17 \text { (decassílabos) } \\
21 \text { e } 49 \text { (dodecassíla- } \\
\text { bos) rimas irregulares de } \\
\text { versificação camoniana. }\end{array}$ \\
\hline $\begin{array}{l}\text { Samuel } \\
\text { MacDowell } \\
\text { Filho }\end{array}$ & $\begin{array}{c}83 \text { sonetos dos } \\
154\end{array}$ & $\begin{array}{c}\text { Jornal do Brasil, } \\
1952 .\end{array}$ & & $\begin{array}{l}\text { Decassílabos de rimas } \\
\text { regulares em uma } \\
\text { linguagem erudita. }\end{array}$ \\
\hline $\begin{array}{c}\text { Péricles } \\
\text { Eugênio da } \\
\text { Silva Ramos }\end{array}$ & $\begin{array}{l}\text { Total de } 45 \text { dos } \\
154 \text { sonetos }\end{array}$ & $\begin{array}{l}1^{\text {a }} \text { ed. Saraiva, } \\
\text { 1953; } \\
2^{\text {a }} \text { ed. Edições de } \\
\text { Ouro,1966; } \\
3^{\text {a }} \text { ed. Ediouro, } \\
\text { s.d.; } \\
4^{\text {a. }} \text { ed. Civilização } \\
\text { Brasileira, 1970; } \\
5^{\underline{a}} \text { ed. Hedra, } \\
\text { 2008. }\end{array}$ & $\begin{array}{l}\text { "Traduzir é, antes } \\
\text { do mais, } \\
\text { compreender" } \\
\text { (2008, p. 9). } \\
\text { "Traduzir } \\
\text { importará, } \\
\text { forçosamente, } \\
\text { recriar" (2008, p. } \\
\text { 11). }\end{array}$ & $\begin{array}{l}\text { Dodecassílabos rimados } \\
\text { e dístico emparelhado } \\
\text { com o objetivo de não } \\
\text { sacrificar o texto. }\end{array}$ \\
\hline $\begin{array}{l}\text { Jerônimo de } \\
\text { Aquino }\end{array}$ & 154 sonetos & $\begin{array}{l}1^{1^{\mathrm{a}}} \text { ed. } \\
\text { Melhoramentos, } \\
\text { 1956; } \\
2^{\text {2 }} \text { ed. Martin } \\
\text { Claret, } 2007 .\end{array}$ & & $\begin{array}{l}\text { Dodecassílabos rimados } \\
\text { com linguagem refinada } \\
\text { e termos arcaizantes, } \\
\text { somando-se a } \\
\text { metaplasmos, inversões, } \\
\text { síncopes e metáteses. }\end{array}$ \\
\hline $\begin{array}{l}\text { Flora } \\
\text { Machmann }\end{array}$ & $\begin{array}{l}\text { Apenas o soneto } \\
27\end{array}$ & $\begin{array}{l}\text { Edição do IV } \\
\text { Centenário, } \\
\text { Leitura S.A, } \\
1964 .\end{array}$ & & $\begin{array}{l}\text { "Versos quase todo em } \\
\text { decassílabos" } \\
\text { (GUEIROS, 2015). }\end{array}$ \\
\hline Geir Campos & $\begin{array}{l}\text { Apenas os } \\
\text { sonetos } 25 \text { e } \\
116\end{array}$ & $\begin{array}{l}\text { Edição do IV } \\
\text { Centenário, } \\
\text { Leitura S.A, } \\
1964 .\end{array}$ & & Decassílabos rimados. \\
\hline $\begin{array}{l}\text { Oscar } \\
\text { Mendes }\end{array}$ & 154 sonetos & $\begin{array}{l}\text { José Aguilar, } \\
1969 .\end{array}$ & $\begin{array}{l}\text { A rima é } \\
\text { essencialmente } \\
\text { música e diversa } \\
\text { é a música de } \\
\text { cada língua. }\end{array}$ & $\begin{array}{l}\text { Versos em alexandrino } \\
\text { clássico de rimas } \\
\text { irregulares. Procurando } \\
\text { corresponder, na medida } \\
\text { de sua compreensão, ao } \\
\text { pensamento do autor. } \\
\text { Optando pelo sentido } \\
\text { em detrimento da forma. }\end{array}$ \\
\hline $\begin{array}{l}\text { Guilherme } \\
\text { Figueiredo }\end{array}$ & $\begin{array}{l}7 \text { dos } 154 \\
\text { sonetos }(22,23 \text {, } \\
55,66,71,91 \text { e } \\
130)\end{array}$ & $\begin{array}{l}3 \text { sonetos - Jornal } \\
\text { da Letras, } 1971 \text { e } \\
4 \text { sonetos - } \\
\text { Edição Cátedra, } \\
1973 .\end{array}$ & 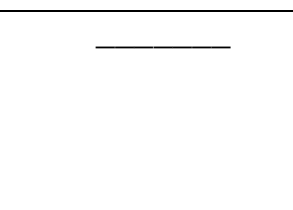 & $\begin{array}{l}\text { Decassílabos de rimas } \\
\text { cruzadas e dístico } \\
\text { emparelhado. }\end{array}$ \\
\hline Ivo Barroso & 50 sonetos & $\begin{array}{l}1^{\text {a }} \text { ed. Nova } \\
\text { Fronteira, 1973; }\end{array}$ & $\begin{array}{l}\text { Busca propor } \\
\text { uma ideia de }\end{array}$ & $\begin{array}{l}\text { Decassílabos rimados e } \\
\text { dístico emparelhado - }\end{array}$ \\
\hline
\end{tabular}




\begin{tabular}{|c|c|c|c|c|}
\hline & & $\begin{array}{l}2^{\text {a }} \text { ed. Nova } \\
\text { Fronteira, 1975; } \\
3^{\text {a }} \text { ed. Nova } \\
\text { Fronteira, 1991; } \\
4^{\text {a }} \text { ed. Nova } \\
\text { Fronteira, 2005; } \\
5^{\underline{a}} \text { ed. Nova } \\
\text { Fronteira, 2015. }\end{array}$ & $\begin{array}{l}\text { tradução como } \\
\text { recriação e não } \\
\text { de uma tradução } \\
\text { meramente } \\
\text { mecânica, como } \\
\text { aponta em seu } \\
\text { prefácio de } 2015 \text {. }\end{array}$ & $\begin{array}{l}\text { propõe uma tradução } \\
\text { mais sucinta, já que não } \\
\text { opta pelo dodecassílabo, } \\
\text { segundo ele. }\end{array}$ \\
\hline $\begin{array}{l}\text { Jorge } \\
\text { Wanderley }\end{array}$ & 154 sonetos & 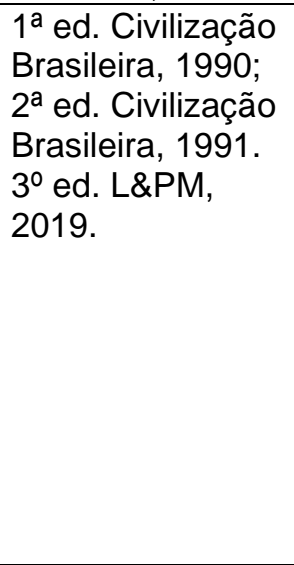 & $\begin{array}{l}\text { O metro e a rima } \\
\text { são elementos } \\
\text { importantes ao } \\
\text { poema. } \\
\text { "Os sonetos } \\
\text { shakespearianos } \\
\text { são basicamente } \\
\text { um ser musical" } \\
\text { (1991, p.19). } \\
\text { "Uma tradução } \\
\text { deve fluir" (1991, } \\
\text { p.20). } \\
\text { Tradução como } \\
\text { negociação. }\end{array}$ & $\begin{array}{l}\text { Decassílabos de rimas } \\
\text { alternadas com dístico } \\
\text { emparelhado. Há um } \\
\text { enfoque no aspecto } \\
\text { formal, entretanto os } \\
\text { elementos semânticos } \\
\text { são negociáveis. }\end{array}$ \\
\hline $\begin{array}{l}\text { Barbara } \\
\text { Heliodora }\end{array}$ & $\begin{array}{l}16 \text { dos } 19 \\
\text { sonetos } \\
\text { traduzidos (sua } \\
\text { mãe, Anna } \\
\text { Amelia, traduziu } \\
\text { os demais.) } \\
\end{array}$ & Ediouro, 2000. & $\begin{array}{l}\text { Na tradução } \\
\text { deve-se levar em } \\
\text { conta as } \\
\text { particularidades } \\
\text { de cada língua. }\end{array}$ & $\begin{array}{l}\text { Decassílabos de rimas } \\
\text { alternadas e dístico } \\
\text { emparelhado. }\end{array}$ \\
\hline $\begin{array}{l}\text { Renata } \\
\text { Cordeiro }\end{array}$ & $\begin{array}{l}17 \text { sonetos ( } 1 \text { ao } \\
17)\end{array}$ & Landy, 2003. & L & $\begin{array}{l}\text { Dodecassílabos com } \\
\text { rimas alternadas e } \\
\text { dístico emparelhado. }\end{array}$ \\
\hline Milton Lins & 154 sonetos & $\begin{array}{l}\text { Edição do } \\
\text { tradutor, } 2005 .\end{array}$ & 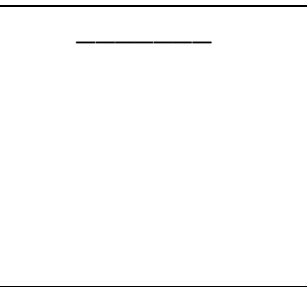 & $\begin{array}{l}\text { Metrificação ora em } \\
\text { decassílabos, ora } \\
\text { dodecassílabos. } \\
\text { Cada quadra traduzida é } \\
\text { seguida da quadra no } \\
\text { original e assim por } \\
\text { diante. }\end{array}$ \\
\hline $\begin{array}{l}\text { Thereza C. } \\
\text { Rocque da } \\
\text { Motta }\end{array}$ & 154 sonetos & $\begin{array}{l}\text { Ibis Libris, 2006; } \\
\text { lbis Libris, 2009. }\end{array}$ & $\begin{array}{l}\text { Os sonetos } \\
\text { shakespearianos } \\
\text { transcendem toda } \\
\text { formalidade e os } \\
\text { versos de uma } \\
\text { tradução devem } \\
\text { revelar a poesia e } \\
\text { não a aprisionar. } \\
\text { A tradução está } \\
\text { repleta de um } \\
\text { jogo de escolhas } \\
\text { de sentido e } \\
\text { relevância. }\end{array}$ & $\begin{array}{l}\text { Enfoca o conteúdo em } \\
\text { detrimento da forma. } \\
\text { Não segue um padrão } \\
\text { rímico, mas a mancha } \\
\text { gráfica tem } 14 \text { versos. } \\
\text { Afirma que houve vezes } \\
\text { que teve de excluir o } \\
\text { que julgou não ser } \\
\text { relevante em português. }\end{array}$ \\
\hline $\begin{array}{l}\text { Jorge Furtado } \\
\text { e Liziane } \\
\text { Kugland } \\
\text { (org.) }\end{array}$ & 29 dos 154 & Objetiva, 2010 & $\begin{array}{l}\text { Segundo consta } \\
\text { na introdução, no } \\
\text { soneto, tudo } \\
\text { começa através } \\
\text { do ritmo e cada } \\
\end{array}$ & $\begin{array}{l}\text { Ora dodecassílabos, ora } \\
\text { decassílabos, ora verso } \\
\text { branco. Nesse volume } \\
\text { diversos artistas foram } \\
\text { convidados para traduzir }\end{array}$ \\
\hline
\end{tabular}




\begin{tabular}{|c|c|c|c|c|}
\hline & & & $\begin{array}{l}\text { língua tem seus } \\
\text { encantos. }\end{array}$ & $\begin{array}{l}\text { um soneto de } \\
\text { Shakespeare. }\end{array}$ \\
\hline $\begin{array}{l}\text { Geraldo } \\
\text { Carneiro }\end{array}$ & $\begin{array}{l}3 \text { sonetos (18, } \\
76 \text { e } 116)\end{array}$ & $\begin{array}{l}\text { Nova Fronteira, } \\
2012\end{array}$ & & $\begin{array}{l}\text { Os versos em } \\
\text { decassílabos são } \\
\text { rimados alternadamente } \\
\text { seguidos do dístico } \\
\text { emparelhado. }\end{array}$ \\
\hline $\begin{array}{l}\text { Oscar } \\
\text { Dourado }\end{array}$ & 154 sonetos & $\begin{array}{l}\text { P55 Edições, } \\
2017 .\end{array}$ & $\begin{array}{l}\text { Se aproxima da } \\
\text { ideia de } \\
\text { Shakespeare } \\
\text { como um poeta } \\
\text { subversivo. } \\
\text { Para ele, o dístico } \\
\text { ao final do soneto } \\
\text { apresenta a } \\
\text { "verdade" do } \\
\text { poema e, } \\
\text { portanto, é o } \\
\text { único recurso que } \\
\text { busca } \\
\text { correspondência } \\
\text { continuamente. }\end{array}$ & $\begin{array}{l}\text { Adota os versos brancos } \\
\text { de rimas mais ou menos } \\
\text { regulares, se esforçando } \\
\text { para apresentar um } \\
\text { resultado melódico nas } \\
\text { rimas. } \\
\text { Predominância dos } \\
\text { tempos verbais: futuro } \\
\text { do pretérito e do modo } \\
\text { subjuntivo. } \\
\text { Enumerou o quinto e o } \\
\text { nono verso para indicar } \\
\text { o início do segundo e do } \\
\text { terceiro quarteto, ao que } \\
\text { parece, esse recurso é } \\
\text { apenas para situar o } \\
\text { leitor. }\end{array}$ \\
\hline Almiro Pisetta & 154 sonetos & $\begin{array}{l}\text { Martin Claret, } \\
2018\end{array}$ & $\begin{array}{l}\text { Embasa-se nas } \\
\text { postulações de } \\
\text { Pound, que foram } \\
\text { adaptadas por } \\
\text { Vizioli, bem como } \\
\text { na ótica de } \\
\text { Horácio acerca } \\
\text { da licença } \\
\text { poética. }\end{array}$ & $\begin{array}{l}\text { Se permite a utilização } \\
\text { de certas liberdades } \\
\text { como anacronismos, } \\
\text { arcaísmos entre outras. } \\
\text { Opta pelos decassílabos } \\
\text { de rimas alternadas } \\
\text { seguidas do dístico de } \\
\text { rimas emparelhadas. } \\
\text { Suas traduções contam } \\
\text { com dois formatos: em } \\
\text { verso e em prosa, } \\
\text { precedidos do original } \\
\text { em inglês. }\end{array}$ \\
\hline Elvio Funck & 154 sonetos & Movimento, 2019 & $\begin{array}{l}\text { Tanto suas } \\
\text { traduções como } \\
\text { as notas } \\
\text { explicativas são } \\
\text { "males } \\
\text { necessários", } \\
\text { contudo, segundo } \\
\text { ele, quanto mais } \\
\text { traduções } \\
\text { existirem, melhor } \\
\text { se verá } \\
\text { Shakespeare. } \\
\text { Além disso, } \\
\text { defende que o } \\
\text { dístico final nos } \\
\text { sonetos é a } \\
\text { "chave de ouro". }\end{array}$ & $\begin{array}{l}\text { Tradução interlinear em } \\
\text { prosa e bilíngue. A } \\
\text { mancha gráfica contem } \\
14 \text { versos brancos com } \\
\text { o dístico final de rimas } \\
\text { emparelhadas, segundo } \\
\text { ele, esse é o elemento } \\
\text { que mais buscou } \\
\text { preservar. Há também o } \\
\text { a tradução do dístico em } \\
\text { francês e alemão para } \\
\text { dar uma visão mais } \\
\text { universal do soneto, e as } \\
\text { notas que seguem no } \\
\text { verso de cada página } \\
\text { têm um cunho didático, } \\
\text { segundo ele. }\end{array}$ \\
\hline
\end{tabular}

Fonte: Autoria própria, 2020. 


\section{APÊNDICE B - Breve troca de mensagens com Oscar Dourado}

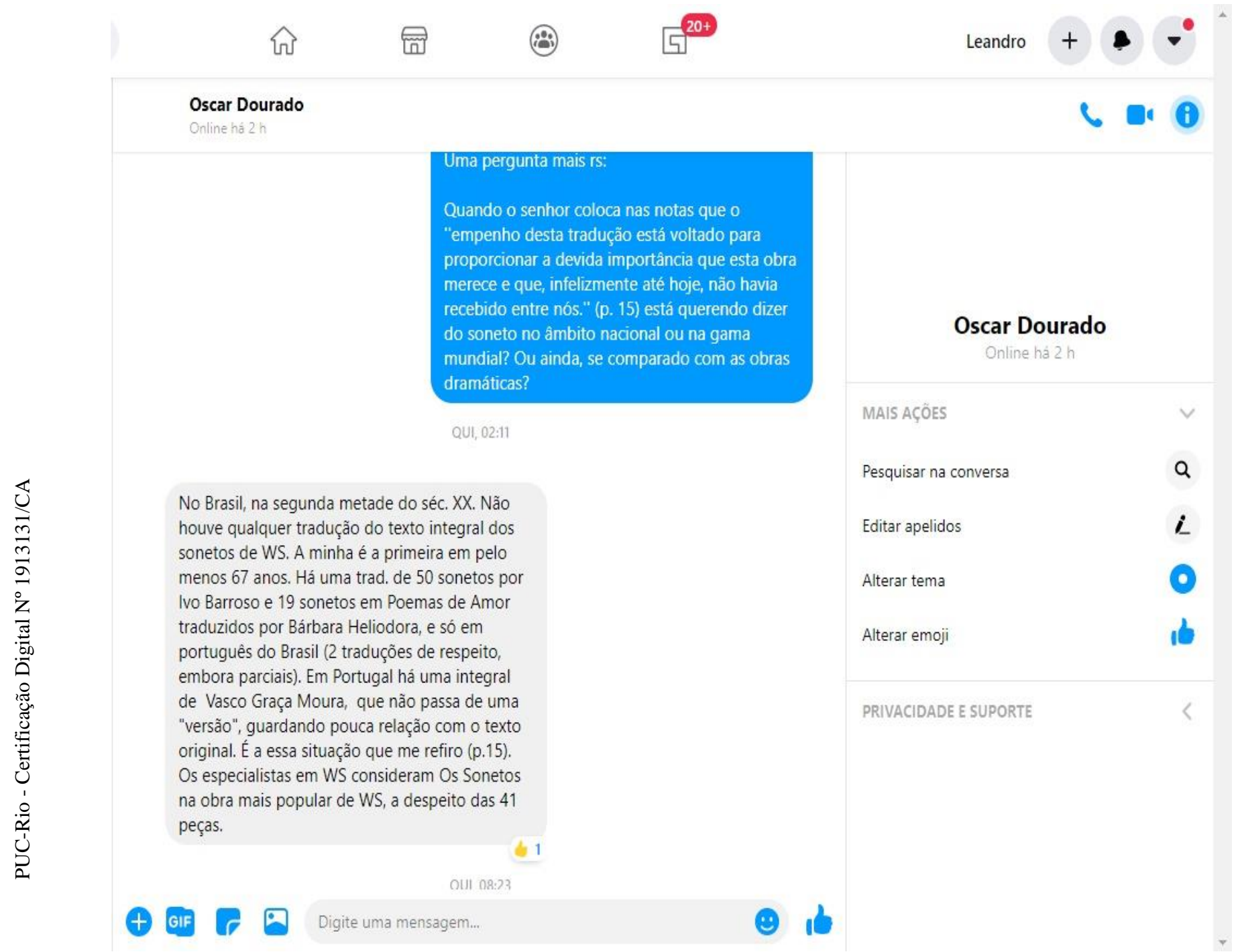

Fonte: Rede social Facebook, 2020. 